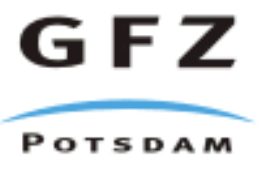

Originally published as:

Hertogen, J., Emmermann, R., Robinson, P. T., Erzinger, J. (2002): Lithology, Mineralogy and Geochemistry of the Lower Ocean Crust, ODP Hole 735B, Southwest Indian Ridge. - Proceedings of the Ocean Drilling Program : Scientific results, 176, 75.

URL: http://www-odp.tamu.edu/publications/176_SR/VOLUME/CHAPTERS/SR176 06.PDF 
Natland, J.H., Dick H.J.B., Miller, D.J., and Von Herzen, R.P. (Eds.)

Proceedings of the Ocean Drilling Program, Scientific Results Volume 176

\section{Lithology, Mineralogy, AND GeOCHEMISTRY OF THE LOWER OCEAN CRUST, ODP HOLE 735B, SOUTHWEST INDIAN RIDGE'}

\author{
Jan Hertogen, ${ }^{2}$ Rolf Emmermann, ${ }^{3}$ Paul T. Robinson, ${ }^{3,4}$ and \\ Jörg Erzinger ${ }^{3}$
}

\begin{abstract}
Ocean Drilling Program (ODP) Hole 735B, located on Atlantis Bank on the Southwest Indian Ridge, penetrated 1508 meters below seafloor with an average recovery of $87 \%$, providing a nearly continuous sample of a significant part of oceanic Layer 3. Based on variations in texture and mineralogy, 12 major lithologic units are recognized in the section, ranging from 39.5 to $354 \mathrm{~m}$ thick. The principal lithologies include troctolite, troctolitic gabbro, olivine gabbro and microgabbro, gabbro, gabbronorite and Fe-Ti oxide gabbro, gabbronorite, and microgabbro. Highly deformed mylonites, cataclasites, and amphibole gneisses are locally present, as are small quantities of pyroxenite, anorthositic gabbro, and trondhjemite. Downhole variations in mineral composition, particularly for olivine and clinopyroxene, show a number of cyclic variations. Plagioclase compositions show the widest variations and correspond to different degrees of deformation and alteration as well as primary processes. Downhole chemical variations correspond reasonably well with variations in mineral compositions. Iron and titanium mainly reflect the presence of Fe-Ti oxide gabbros but show some cyclical variations in the lower part of the core where oxide gabbros are sparse. $\mathrm{CaO}$ is highly variable but shows a small but consistent increase downhole. $\mathrm{MgO}$ is more uniform than $\mathrm{CaO}$ and shows a very small downward increase. Sulfur and $\mathrm{CO}_{2}$ contents are generally low, but $\mathrm{S}$ shows significant enrichment in lithologic Unit IV, which consists of
\end{abstract}

${ }^{1}$ Hertogen, J., Emmermann, R., Robinson, P.T., and Erzinger, J., 2002. Lithology, mineralogy, and geochemistry of the lower ocean crust, ODP Hole 735B, Southwest Indian Ridge. In Natland, J.H., Dick, H.J.B., Miller, D.J., and Von Herzen, R.P. (Eds.), Proc. ODP, Sci. Results, 176, 1-82 [Online]. Available from World Wide Web: <http://www-odp.tamu.edu/ publications/176_SR/VOLUME/ CHAPTERS/SR176_06.PDF $>$. [Cited YYYY-MM-DD]

${ }^{2}$ Afdeling Fysico-chemische geologie, University of Leuven, Celestijnenlaan, 200C1, B-3001 Heverlee, Belgium.

${ }^{3}$ GeoForschungsZentrum,

Telegrafenberg, D-14473 Potsdam, Germany.

${ }^{4}$ Permanent address: Centre For Marine Geology, Dalhousie University, Halifax NS, Canada B3H 3J5. Correspondence author: robinso@is.dal.ca

Initial receipt: 24 September 2000 Acceptance: 4 December 2001 Web publication: 21 June 2002 Ms 176SR-003 
Fe-Ti oxide gabbro, reflecting the presence of sulfide minerals in the sequence. The lithologic, mineralogical, and geochemical data provided here will allow detailed comparisons with ophiolite sections as well as sections of in situ ocean crust drilled in the future.

\section{INTRODUCTION}

Through dredging and shallow drilling, a great deal has been learned over the last $30 \mathrm{yr}$ about the lithology and geochemistry of the basaltic rocks that make up seismic Layer 2 of the ocean basins. However, relatively little is known about the lower crust because these rocks are rarely exposed on the seafloor and thus are difficult to dredge or drill. Based on sparse dredge hauls and comparisons with ophiolites, seismic Layer 3 is believed to consist primarily of mafic plutonic rocks, although in Hole 504B, the boundary between Layers 2 and 3 appears to lie within the sheeted dike section (Detrick et al., 1994).

During Ocean Drilling Program Leg 118 in 1987, foliated gabbros were found exposed on the seafloor in $720 \mathrm{~m}$ of water atop Atlantis Bank on the Southwest Indian Ridge (Fig. F1). Atlantis Bank is a flattopped feature $\sim 9 \mathrm{~km}$ long in a north-south direction and $4 \mathrm{~km}$ wide (Dick et al., 1991b) that was unroofed by a detachment fault (Dick et al., 1991c, 1992). The JOIDES Resolution spudded Hole 735B on this outcrop and drilled to a depth of 504.7 meters below seafloor (mbsf) before the hole was terminated for lack of time. The hole penetrated a sequence of troctolite, gabbro, olivine gabbro, gabbronorite, and Fe-Ti oxide gabbro with physical properties and seismic velocities appropriate for oceanic Layer 3 (Robinson, Von Herzen, et al., 1989; Iturrino et al., 1991). Although similar in some respects to typical ophiolites, the drilled section was characterized by a high degree of deformation, an abundance of Fe-Ti oxide gabbro, and local, high-grade metamorphism (Von Herzen, Robinson, et al., 1991).

In 1997, the JOIDES Resolution returned to Hole 735B and deepened it to 1508 mbsf before the drill pipe broke and could not be retrieved. Core recovery on both legs was $87 \%$, thus providing an almost continuous 1.5-km-thick section of the lower crust. The overall lithology of the core and its general character is described in Robinson, Von Herzen, et al. (1989) and Shipboard Scientific Party (1999). In this report, we present results on the petrography, mineralogy, and geochemistry of this section of lower ocean crust. The tables and figures contain new data for samples collected during both Legs 118 and 176, as well shipboard geochemical data produced during Leg 176 and phase chemistry previously published by Hébert et al. (1991), Ozawa et al. (1991), and Natland et al. (1991).

\section{LITHOLOGY OF HOLE 735B}

Nine principal lithologies are recognized in Hole 735B: troctolite, troctolitic gabbro, olivine gabbro, olivine microgabbro, gabbro, gabbronorite, Fe-Ti oxide gabbronorite, Fe-Ti oxide gabbro, and Fe-Ti oxide microgabbro (Shipboard Scientific Party, 1999). In addition, small quantities of pyroxenite, anorthositic gabbro, and trondhjemite occur sporadically in the section. Highly deformed mylonites, cataclasites, and amphibole gneisses are also locally present, particularly in the upper part of the hole. By far, the most abundant rock types are olivine
F1. Location of Hole 735B on the Southwest Indian Ridge, p. 28.

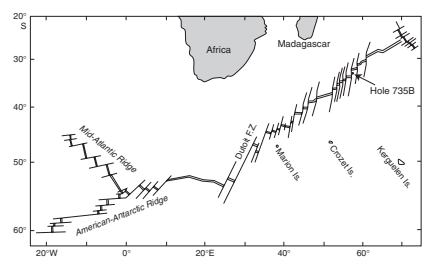


gabbro and olivine microgabbro, which together make up $\sim 60 \%$ of the core (Fig. F2). Gabbros with less than 5 modal\% olivine are the next most voluminous rock type, followed by troctolite and troctolitic gabbro. Although most of the gabbros and olivine gabbros have trace amounts of orthopyroxene, only rarely does this mineral exceed 5 modal\%. However, because of its petrologic significance, samples in which orthopyroxene appears as discrete grains have been classified as gabbronorites, even when orthopyroxene is less than 5 modal\% (Shipboard Scientific Party, 1999). The gabbronorites tend to be associated with Fe-Ti oxide gabbros and microgabbros, and the three combined make up $10 \%$ of the recovered core.

A total of 952 individual lithologic intervals were recognized in the core on the basis of textural and mineralogical variations (Dick et al., 1991a; Shipboard Scientific Party, 1999). These in turn, are grouped into 12 major lithologic units primarily on the basis of their mineralogy (Fig. F2).

\section{Unit I (0-39.5 mbsf): Metagabbro}

Unit I is a 39.5 -m-thick sequence of foliated metagabbro with porphyroclastic to mylonitic textures. The least altered samples consist chiefly of neoblastic plagioclase and clinopyroxene with a few porphyroclasts of feldspar and pyroxene. In most samples the pyroxene has been replaced by greenish brown amphibole, producing banded amphibole gneisses. The protolith of these metamorphic rocks was a twopyroxene gabbro or gabbronorite based on the common presence of orthopyroxene porphyroclasts. Small amounts of olivine are preserved in some of the freshest intervals.

Although this interval has been intensely deformed and metamorphosed, low-temperature alteration is minor. Some of the olivine is replaced by colorless amphibole and talc, and much of the pyroxene has been replaced by greenish brown amphibole. Amphibole and amphibole + sodic plagioclase veins, up to $1.5 \mathrm{~mm}$ wide, commonly cut the foliation at a high angle.

\section{Unit II (39.5-180.0 mbsf): Olivine Gabbro}

Unit II consists of $140.5 \mathrm{~m}$ of olivine gabbro and olivine-bearing gabbro with weak grain size and modal layering. Its upper boundary is marked by a sharp decrease in crystal-plastic deformation and its lower boundary by a relatively rapid increase in the modal proportions of orthopyroxene. A basaltic dike cuts this unit in Core 176-735B-19R, and there are a few thin layers of Fe-Ti oxide gabbro interspersed with the olivine gabbros. Although much less deformed than Unit I, this section contains a number of thin mylonitic and porphyroclastic bands.

Background alteration in Unit II is relatively high, ranging from a low of $\sim 5 \%$ to a high of $>80 \%$ (Stakes et al., 1991). Olivine is partially to completely replaced by $\mathrm{Mg}$-amphibole and talc or by green smectite, and pyroxene is rimmed and partly replaced by greenish brown amphibole. Plagioclase is typically the least altered mineral but is locally replaced by more sodic feldspar or epidote. Alteration is typically most intense in zones of crystal-plastic or brittle deformation.
F2. Lithologic column for Hole 735B showing the 12 major lithologic units, p. 29.

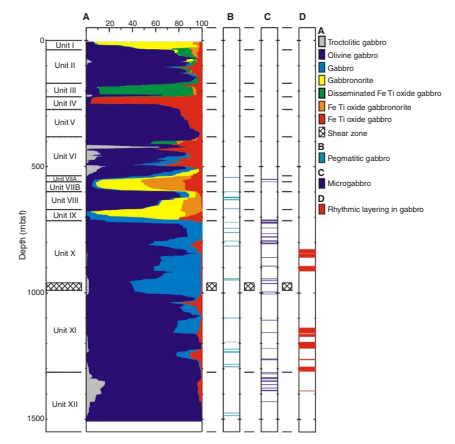




\section{Unit III (180.0-224.0 mbsf): Olivine Gabbro}

Unit III is a 44-m-thick sequence of predominantly olivine gabbro with well-preserved igneous textures and a well-developed igneous lamination. A few thin bands of Fe-Ti oxide gabbro are intercalated with the olivine gabbro. The upper boundary is marked by a downward increase in orthopyroxene and Fe-Ti oxides and the lower boundary by a shear zone, across which there is a sharp downward increase in Fe-Ti oxide. The mineralogical composition of Unit III suggests that it is more evolved than the overlying olivine gabbros.

Background alteration in this unit is similar in character to that in the overlying Unit II but is somewhat less intense, largely because the rocks are less deformed. Total alteration rarely exceeds 50\%, although it may be higher in narrow intervals.

\section{Unit IV (224.0-272.0 mbsf): Fe-Ti Oxide Gabbro}

A unique sequence of Fe-Ti oxide-rich gabbro, $48 \mathrm{~m}$ thick, makes up Unit IV. The rocks are similar in mineralogy to those of Unit III, but the proportion of Fe-Ti oxides is much higher. The gabbro is typically coarse to very coarse grained and commonly has a well-developed subhorizontal magmatic foliation. The abundant Fe-Ti oxides (both magnetite and ilmenite) form intergranular to poikilitic masses enclosing or partly enclosing plagioclase and pyroxene. Overall deformation is weak in this unit, but there are a few thin mylonitic bands in the upper part and the base of the unit is marked by a 2 - to 3 -m-thick zone of mylonitized oxide gabbro.

Background alteration is also relatively weak in this interval, rarely exceeding $20 \%$, because of both its low olivine content and its weakly deformed nature. Small amounts of secondary sulfide minerals are present in these oxide-rich gabbros, and sodic feldspar and chlorite locally replace plagioclase. Veins are relatively abundant in this interval (locally up to $25 \%$ of the core) and are mostly felsic or plagioclase + diopside in composition.

\section{Unit V (272.0-403.5 mbsf): Olivine Gabbro}

A 131.5-m-thick sequence of relatively homogeneous olivine gabbro makes up Unit V. The upper contact lies at the base of a distinct mylonite zone, and the lower contact is marked by the appearance of pervasive, weak to moderate deformation that characterizes all of Unit VI. Overall, Unit $\mathrm{V}$ is marked by an absence of deformation, although some weak grain size layering is visible. Nearly all of the rocks contain 5\% or more olivine, and a few are troctolitic in composition. A few bands of Fe-Ti oxide gabbro are present, and one layer of orthopyroxene-bearing microgabbro occurs near the base of the unit.

The olivine in Unit $\mathrm{V}$ is partly altered to either colorless amphibole or green smectite, and pyroxene is rimmed and partly replaced by greenish brown amphibole. Most of this unit is relatively fresh with background alteration $<20 \%$; however, it may exceed $80 \%$ in local shear zones. Likewise, veins are generally sparse, rarely exceeding $5 \%$ of the core. 


\section{Unit VI (403.5-536.0 mbsf): Olivine Gabbro and Troctolite}

Unit VI is a long sequence of coarse-grained, relatively homogeneous olivine gabbro and troctolite characterized by a weak to moderate deformation. Overall, the rocks of Unit VI are similar to those of Unit V but somewhat more primitive, as indicated by a higher modal abundance of olivine and the common presence of troctolite layers. Thin layers and lenses of olivine microgabbro are locally interleaved with the dominant lithology.

Background alteration in this unit is relatively low except at the base where it can be up to $60 \%$. Again, the most common styles of alteration are colorless amphibole + talc or green smectite after olivine and greenish brown amphibole after clinopyroxene. Sodic feldspar and small amounts of epidote locally replace plagioclase. Veins average $\sim 5 \%$ of this interval but can be more abundant locally. Felsic veins are the most common variety, but calcite veins occur below $500 \mathrm{~m}$. Where calcite veins are present, olivine and some pyroxene are typically replaced by red iron oxyhydroxides.

\section{Unit VII (536.0-599.0 mbsf): Gabbronorite and Oxide Gabbronorite}

$63 \mathrm{~m}$ of gabbronorite and oxide gabbronorite, locally crosscut by oxide-bearing rocks, makes up Unit VII. The upper contact is marked by the downward disappearance of the troctolites and olivine-rich gabbro that characterize Unit VI, whereas the base is defined by a marked downward increase in grain size and modal abundance of olivine. Although Unit VII contains relatively evolved rocks like those of Units III and IV, it has only a few oxide layers and bands.

Unit VII is one of the most intensely altered parts of the Hole 735B core, in which the rocks are on average $10 \%$ to $40 \%$ altered. However, there are many narrow intervals with even higher alteration-up to $90 \%$. Olivine is sparse in this unit and is mostly replaced by Mg-rich amphibole, green smectite, or red iron oxyhydroxides, the latter being particularly common in areas where carbonate veins are abundant. Plagioclase is partly replaced by more sodic feldspar and locally by epidote, whereas pyroxene is typically rimmed with greenish brown amphibole. Some of the orthopyroxene has also been replaced by oxyhydroxides. Local variations in alteration intensity are typically related to vein abundance.

\section{Unit VIII (599.0-670.0 mbsf): Olivine Gabbro}

Unit VIII marks a return to relatively coarse grained olivine gabbro. The unit is $71 \mathrm{~m}$ thick and has distinct upper and lower contacts, marked by changes in grain size and modal mineralogy. In addition to the dominant olivine gabbro, this unit contains a few intervals of gabbronorite, oxide-rich gabbronorite, and oxide-rich gabbro.

Alteration in Unit VIII is similar to that in Unit VII but generally less intense. Felsic and plagioclase + diopside veins are abundant in a narrow zone at $\sim 640$ mbsf, and carbonate veins are also present in small quantities throughout the unit. Olivine is partly replaced by smectite and pyroxene by greenish brown amphibole. 
Unit IX (670.0-714.0 mbsf): Gabbronorite

A sharp decrease in grain size and in the modal proportion of olivine and an increase in the amount of gabbronorite distinguish Unit IX from Unit VIII. Except for having somewhat fewer oxide-rich layers, it is similar to Unit VII in lithology and mineralogy. The unit is $44 \mathrm{~m}$ thick, and its base is taken as the lowest occurrence of noritic rocks.

In Unit IX, background alteration is generally $<20 \%$, although it can be higher in narrow intervals. It chiefly involves replacement of pyroxene by greenish brown amphibole. Plagioclase + amphibole veins are locally abundant, and a few carbonate veins are also present.

\section{Unit X (714.0-960.0 mbsf): Olivine Gabbro and Gabbro}

The top of Unit $\mathrm{X}$ at 714 mbsf is marked by a sharp downward increase in grain size and in the modal abundance of olivine. Unit $X$ consists almost entirely of olivine gabbro and gabbro with very few oxide gabbros. Rhythmic igneous layering is present between 827 and 914 mbsf, and there are both pegmatitic and micrograbbroic intervals in the upper part of the unit. Its lower contact is the top of a 30-m-thick shear zone at 960 mbsf.

A zone with localized bands of intense recrystallization occurs between $\sim 800$ and 960 mbsf, where the rocks exhibit extensive hightemperature crystal-plastic deformation. For the most part, alteration involves replacement of olivine by colorless amphibole and pyroxene by greenish brown amphibole. Veins are sparse throughout the unit but a few carbonate veins occur in the upper $100 \mathrm{~m}$.

\section{Unit XI (960.0-1314.0 mbsf): Olivine Gabbro}

Like Unit $\mathrm{X}$, this unit consists almost entirely of olivine gabbro but is distinguished from the former by an abundance of thin intervals of oxide gabbro. However, the overall abundance of oxide gabbros is less than in either Unit VII or IX. The sequence is $354 \mathrm{~m}$ thick, and its lower boundary at 1314 mbsf is defined by the disappearance of oxide-rich bands. Rhythmic layering occurs in the interval between 1138 and $1220 \mathrm{mbsf}$, and there are irregular variations in grain size and texture throughout the unit.

Below 960 mbsf, background alteration decreases markedly, typically to $<5 \%$ except in rare, discrete intervals. Olivine shows weak alteration, mostly to smectite, and pyroxene is only rimmed with amphibole. Smectite and smectite + carbonate veins are relatively common in the lower $250 \mathrm{~m}$ of the unit, but their effects on the adjacent rock are limited.

\section{Unit XII (1314.0-1508.0 mbsf): Olivine Gabbro}

Unit XII is a monotonous sequence of very uniform, coarse-grained olivine gabbro and troctolitic gabbro with almost no other lithologiesonly a few, very thin oxide-rich bands are present. In the upper part of the unit, thin bands of microgabbro intrude and crosscut the coarsergrained host rock. Pegmatitic intervals characterized by very coarse grained olivine are locally present, as are a few patches of leucogabbro. 
J. HeRTOGEN ET AL.

Lithology, Mineralogy, AND Geochemistry of The LoWer OCEAN Crust

Most of the rocks in the unit are extremely fresh, commonly with $<1 \%$ background alteration. Smectite \pm carbonate and zeolite prehnite veins occur sparsely throughout the unit.

\section{PETROGRAPHIC, MODAL, AND MINERAL COMPOSITIONAL DATA}

\section{Analytical Techniques}

Textural and mineralogical descriptions of Hole 735B core are based on shipboard data and descriptions of 298 thin sections by the authors. Modal mineralogy was determined by point counting (500-1500 points per thin section, depending on grain size) (Robinson, Von Herzen, et al., 1989; Dick, Natland, Miller, et al., 1999) and by X-ray diffraction (XRD) analysis using the technique of Emmermann and Lauterjung (1990). For the XRD analyses, samples were prepared by mixing $3 \mathrm{~g}$ of rock powder with a few drops of polyvinyl alcohol and pressing the powder into a briquette. The analyses were carried out using a quantitative phase analysis procedure on a Siemens D 501 X-ray diffractometer using $\mathrm{CuK}_{\alpha}$ radiation generated at $40 \mathrm{kV}$ and $20 \mathrm{nA}$ and mineral phases were identified and quantified using a "multi-iterative" algorithm developed by Emmermann and Lauterjung (1990). Samples with high water contents were analyzed several times, and in all but three samples the replicate analyses produced virtually identical results. All analyses were normalized to $100 \%$. Comparison of the results with pointcounted data indicate a $2-\sigma$ error on major mineral phases between $5 \%$ and $10 \%$. Minor phases, such as calcite and chlorite, were commonly identified in the spectra but could not be determined quantitatively.

Microprobe analyses were carried out on representative samples of all rock types from Hole 735B. Analyses for Leg 118 samples were carried out at Justus-Liebig Universität, Giessen, Germany, using a Cameca SX50 wavelength-dispersive microprobe. Operating conditions were $15 \mathrm{kV}$ gun voltage and $20 \mathrm{nA}$ sample current with a counting time of $120 \mathrm{~s}$. A variety of natural standards was used for calibration, and counting times for different elements varied, depending on the element concentration. Duplicate analyses indicated a precision of $>2 \%$ of the amount present for abundant oxides and $>5 \%$ for sparse oxides such as $\mathrm{MnO}$, $\mathrm{K}_{2} \mathrm{O}$, and $\mathrm{P}_{2} \mathrm{O}_{5}$. Instrument drift was negligible, as determined by periodic analysis of standard minerals.

Leg 176 samples were analyzed at Dalhousie University, Halifax, Canada, using a JEOL 733 energy-dispersive microprobe. Operating conditions were $15 \mathrm{kV}$ gun voltage and $15 \mathrm{nA}$ sample current, and each spectrum was accumulated for $40 \mathrm{~s}$. Geologic standards were used for calibration, and the results were calculated using the Link's ZAF (atomic number, absorption, and fluorescence) matrix correction program. Analytical precision was $>2 \%$ of the amount present for abundant oxides and $>5 \%$ for sparse oxides. Mineral formulas were calculated for all analyses, and any deviating significantly from stoichiometry were rejected.

\section{Analytical Results}

The major igneous rock types in Hole 735B are defined on variations in grain size and modal proportions of primary minerals. Average 
point-counted modes for the freshest samples of each rock type are given in Table T1. The metagabbros of lithologic Unit I are not included in this table because they are partly to completely recrystallized metamorphic rocks formed at high temperatures and are defined on the basis of their textures and secondary mineralogies. Their protoliths are deduced from relict porphyroclasts, metamorphic mineral assemblages, and the compositions of adjacent igneous units.

Modal data determined by XRD techniques on both fresh and altered rocks from Hole 735B are given in Table T2. In Table T3, these data are used to calculate an average modal composition for the lithologic units described above.

Average mineral compositions of the primary phases in each rock type are given in Table T4. Representative analyses of olivine, orthopyroxene, clinopyroxene, plagioclase, and ilmenite are given in Tables T5, T6, T7, T8, and T9, respectively. Downhole plots of compositional data for olivine, orthopyroxene, clinopyroxene, and plagioclase given in Figures F3, F4, F5, and F6, respectively. The range of composition for each mineral within each sample is given by the length of the bars in the figures.

\section{Metagabbro}

Metagabbros occur in shear zones throughout Hole 735B but are concentrated in lithologic Unit I at the top of the section. These are metamorphic rocks in which primary textures and minerals have been almost completely replaced. Most have well-developed mylonitic or porphyroclastic textures with good foliations. Completely metamorphosed rocks are amphibole gneisses with alternating bands of greenish brown magnesio-hornblende and recrystallized plagioclase (Table T3). A few samples still contain neoblasts of clinopyroxene, indicating metamorphism under relatively anhydrous conditions. Relict grains of plagioclase, clinopyroxene, orthopyroxene, and Fe-Ti oxide occur as porphyroclasts in the recrystallized matrix. Most of these grains are $<5$ $\mathrm{mm}$ across and are rounded or elliptical in shape.

Protolith compositions are difficult to determine because of the extensive metamorphism but can be estimated from the least altered samples. Most of Unit I down to 26.5 mbsf (upper part of Core 176-735B7D) was probably originally gabbronorite judging from the common appearance of orthopyroxene porphyroclasts and the paucity of olivine. These rocks have highly variable proportions of plagioclase, clinopyroxene, orthopyroxene, and amphibole. Altered olivine is recognized in only three samples but could have been more abundant originally. Small grains of Fe-Ti oxide are present in some samples but rarely exceed 3 modal $\%$. Most of the oxide is clearly secondary because it fills fractures perpendicular to the foliation, occurs preferentially in the porous parts of the rocks, and is sometimes associated with postdeformational development of green amphibole.

Below 26.5 mbsf in Unit I, relict olivine is found in most metagabbros, whereas orthopyroxene rarely exceeds 2 modal\% and is commonly absent altogether. A few samples have up to 5 modal\% orthopyroxene, but these are rare. The olivine metagabbros consist of $\sim 5$ modal $\%$ olivine, 43\% plagioclase (including neoblasts), 38\% clinopyroxene (including neoblasts), $1 \%$ orthopyroxene, $2 \%$ magnetite, and 10\% amphibole (mostly replacing pyroxene).
T1. Average primary modal compositions of major lithologies, p. 61.

T2. Modal data by X-ray diffraction analysis, p. 62.

T3. Average modal compositions of lithologic units, p. 64 .

T4. Average compositions of minerals in major rock types, p. 65.

$\overline{\text { T5. Representative olivine compo- }}$ sitions for major rock types, p. 66.

$\overline{\text { T6. Representative orthopyroxene }}$ compositions for major rock types, p. 69.

T7. Representative clinopyroxene compositions for major rock types, p. 71.

T8. Representative plagioclase compositions for major rock types, p. 74 .

T9. Representative ilmenite compositions for major rock types, p. 79.

F3. Downhole variation of olivine compositions (Fo), p. 30.

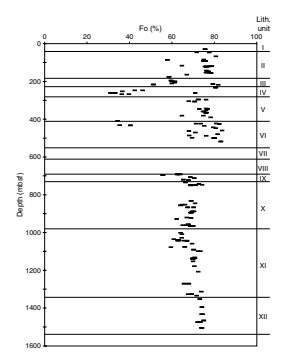




\section{Olivine Gabbro and Olivine Microgabbro}

Olivine gabbros and olivine microgabbros ( $>5$ modal\% olivine) are by far the most abundant lithologies in Hole $735 \mathrm{~B}$, making up 60\% of the total core. They are the principal lithologies in Units II, III, V, VI, VIII, X, XI, and XII, and they occur locally in all the other units (Fig. F2). The olivine gabbros and microgabbros are very similar in modal composition and differ primarily in grain size. Modal mineralogies vary considerably because of phase layering and the irregular distribution of minerals in the rock, but an average mode consists of $\sim 60 \%$ plagioclase, $30 \%$ clinopyroxene, and 10\% olivine, with trace amounts of orthopyroxene, opaque minerals, and amphibole (Table T1). Grain size variations in these rocks can be either abrupt or gradational, but sharp intrusive contacts are rare.

In the olivine gabbros, the grain size is typically $1-2 \mathrm{~mm}$, but crystals can range up to $15 \mathrm{~mm}$ across in very coarse patches. Olivine forms irregular, commonly amoeboidal grains, many of which have narrow, discontinuous rims of orthopyroxene. The average olivine composition in these rocks is $\mathrm{Fo}_{82}$ and the orthopyroxene rims average about $\mathrm{En}_{67}$ (Table T4), although both show a wide range in composition (Tables T5, T6). Clinopyroxene forms large tabular grains, commonly with exsolution lamellae of orthopyroxene. The clinopyroxene is all augite with an average composition of $\mathrm{En}_{46}$ (Tables T4, T7). Plagioclase consists of subhedral, lath-shaped, tabular or blocky grains, typically 1-3 $\mathrm{mm}$ in maximum direction. It has an average composition of $\mathrm{An}_{51}$ (Table T4), but it varies widely because of zoning and background alteration (Table T8).

Alteration in the olivine gabbros and microgabbros varies considerably depending on their position in the hole and proximity to veins. In the lower $500 \mathrm{~m}$ of the hole, background alteration is typically $<5 \%$. In these rocks, olivine is slightly replaced by smectite and secondary magnetite; clinopyroxene is partly rimmed by greenish brown amphibole; and plagioclase is fresh. Elsewhere in the section, olivine is partly to completely replaced by mixtures of $\mathrm{Mg}$-amphibole and talc, or rarely by red iron oxides. Clinopyroxene commonly contains flakes of brown amphibole within the crystals and exhibits extensive marginal replacement by greenish brown amphibole. Plagioclase is partly replaced by more sodic feldspar, epidote, chlorite, clay minerals, and less commonly by amphibole.

\section{Troctolite and Troctolitic Gabbro}

Troctolites in Hole 735B are very mafic rocks with $<5$ modal\% pyroxene and up to 30 modal\% olivine, whereas the troctolitic gabbros have $>10$ modal\% pyroxene and $\sim 15$ modal\% olivine. The volume of these rocks is relatively small, and most of them occur in lithologic Units VI, VII, X, and XII (Fig. F2). They typically form intrusive veins and dikes, up to $1.5 \mathrm{~m}$ thick, in the host olivine gabbros.

The troctolites have an average modal composition of $66.5 \%$ plagioclase, $29.5 \%$ olivine, $3.5 \%$ augite, and $0.5 \%$ of orthopyroxene, opaque minerals, and amphibole combined (Table T1). Traces of apatite and rare spinel are also present. The troctolitic gabbros are similar in composition but have notably lower olivine (17 modal\%) and higher augite (Table T1). Olivine forms euhedral to subhedral crystals up to $\sim 3 \mathrm{~mm}$ in diameter in the troctolites and appears to be cumulus in origin. In the troctolitic gabbros, it is finer grained (average $=\sim 1 \mathrm{~mm}$ ) and equigranular. Augite forms anhedral, interstitial grains in both troctolites and
F4. Downhole variation of orthopyroxene compositions (Mg\#), p. 31.

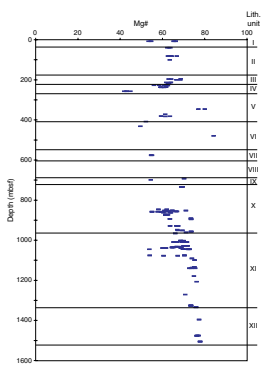

F5. Downhole variation of clinopyroxene compositions (Mg\#), p. 32.

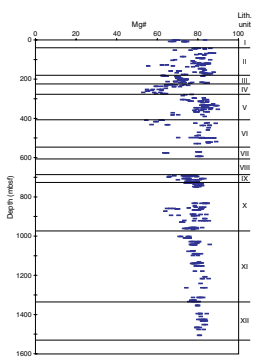

F6. Downhole variation of plagioclase compositions (An content), p. 33.

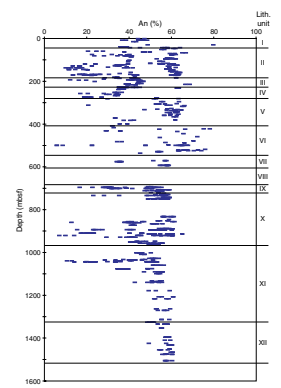




\section{J. HERTOGEN ET AL.}

troctolitic gabbros and ranges from 0.5 to $1 \mathrm{~mm}$ in diameter. Plagioclase occurs both as relatively large subhedral prisms and as anhedral interstitial grains intergrown with pyroxene.

The troctolites and troctolitic gabbros are the most mafic rocks encountered in Hole 735B. Average olivine compositions range from $\mathrm{Fo}_{80.6}$ in the troctolites to $\mathrm{FO}_{83.2}$ in the troctolitic gabbros (Table T4), and individual grains range up to $\mathrm{Fo}_{83.7}$ (Table T5). Orthopyroxene is rare in these rocks, occurring only as narrow rims on some olivine crystals. The sparse clinopyroxene forms subhedral, intergranular to poikilitic grains with rare exsolution lamellae of orthopyroxene. Both the orthopyroxene and clinopyroxene are highly magnesian (Tables T4, T6, T7), although the En content of the clinopyroxene is similar to that of the gabbros and olivine gabbros (Table T4). Plagioclase is highly calcic, ranging from an average of $\mathrm{An}_{65.0}$ in the troctolites to $\mathrm{An}_{74.3}$ in the troctolitic gabbros (Tables T4, T8).

Most of the troctolites and troctolitic gabbros occur in the lower parts of the hole where veins are sparse and alteration is slight. Olivine in these rocks is commonly fresh or exhibits only minor replacement by smectite along cracks. Pyroxene is also relatively fresh, typically having only a few flakes of brown amphibole within individual grains. In a few cases, clinopyroxene grains also show marginal replacement by brownish green amphibole. Plagioclase is fresh or very slightly replaced by clay minerals or green amphibole.

\section{Gabbro}

Gabbros are relatively sparse in Hole $735 \mathrm{~B}$ and occur as thin intervals in the dominant olivine gabbro, especially in lithologic Units X, XI, and XII (Fig. F2). Nearly all of these rocks are olivine bearing and are mineralogically similar to the olivine gabbros. An average mode consists of $58 \%$ plagioclase, $37 \%$ clinopyroxene, $3.5 \%$ olivine, and small amounts of orthopyroxene, opaque minerals, amphibole, and apatite (Table T1). Modal layering is locally present, with the rocks alternating between gabbro and olivine gabbro.

Most of the gabbros are coarse-grained, granular rocks commonly with a weak magmatic foliation, although a few microgabbros are also present. Plagioclase typically forms relatively large, subhedral, prismatic to blocky grains, $1-3 \mathrm{~mm}$ across. Clinopyroxene occurs as subhedral, tabular grains ranging up to $10 \mathrm{~mm}$ across in very coarse grained intervals. Olivine forms small, anhedral grains, commonly with narrow, discontinuous rims of orthopyroxene where it is in contact with plagioclase.

Although most of the gabbros are olivine bearing, they are somewhat more evolved than the olivine gabbros and troctolites. Olivine is relatively uniform in composition with an average of $\mathrm{FO}_{71.6}$ distinctly more iron rich than that in the olivine gabbros, whereas plagioclase is nearly identical in composition in the two rock types (Tables T4, T5, T8). The sparse orthopyroxene has an average composition of $\mathrm{En}_{69.6}$, slightly more magnesian than the average in olivine gabbros (Table T4), but this may be a function of the small sample population. Clinopyroxene has almost identical En contents in the two rock types (Table T4) but is slightly more iron rich in the gabbros with Mg\#s ranging from 75-80.

Like the olivine gabbros, most of these rocks are only weakly altered, although a few samples in the upper part of the hole show extensive replacement of olivine and pyroxene. Where alteration is most intense, 


\section{J. HERTOGEN ET AL.}

the olivine is partly to completely replaced by colorless amphibole and rare talc; elsewhere it is partially replaced by green smectite. Pyroxene is typically rimmed and partially replaced by brownish green amphibole, and plagioclase is locally bleached and replaced by more sodic varieties.

\section{Gabbronorite}

Gabbronorite occurs primarily in lithologic Units I, VII, and IX, although it forms thin intervals elsewhere in the sequence (Fig. F2). The gabbronorites are closely associated with Fe-Ti oxide gabbros and gabbronorites and are concentrated in zones of moderate to intense crystalplastic deformation.

In Unit I, most of the rocks are strongly deformed metagabbros but primary orthopyroxene appears to have been present throughout the section, based on the presence of numerous porphyroclasts. The original abundance of orthopyroxene is difficult to determine but may have been as much as 10 modal\%. An average modal composition for unmetamorphosed gabbronorites elsewhere in the core is $64 \%$ plagioclase, $2.5 \%$ olivine, $27 \%$ clinopyroxene, $4.5 \%$ orthopyroxene, $1 \%$ opaque minerals and $1 \%$ amphibole (Table T1). Although these rocks rarely contain more than 5 modal\% orthopyroxene, they were classified as gabbronorites by the shipboard party to emphasize their petrologic importance. The few samples containing more than 5 modal\% olivine are best classified as olivine gabbronorite.

The plagioclase in these rocks forms subhedral laths or tabular crystals up to $\sim 2 \mathrm{~mm}$ across or minute neoblasts in the groundmass of deformed samples. Clinopyroxene can also occur as neoblasts but more commonly forms tabular crystals or subrounded porphyroclasts 2-3 $\mathrm{mm}$ across. Olivine rarely forms $>2-3$ modal $\%$ in these rocks and occurs as anhedral grains 1-2 $\mathrm{mm}$ across. Although orthopyroxene is not abundant, it typically forms discrete grains, usually 0.5 to $1 \mathrm{~mm}$ across. It can also occur as narrow rims on olivine or as exsolution lamellae in clinopyroxene grains.

The gabbronorites are highly evolved rocks in which plagioclase has an average composition of $\mathrm{An}_{39}$ with a standard deviation of 6.1 (Table T4). The most calcic plagioclase in these rocks is $\mathrm{An}_{48.5}$ (Table T8); thus strictly speaking, they should be classified as diorites. Orthopyroxene has an average composition of $\mathrm{En}_{61}$, significantly more iron rich than the orthopyroxene in the gabbros and olivine gabbros (Tables T4, T6). Clinopyroxene is also relatively iron rich with an average composition of $\mathrm{En}_{39}$ (Table T7), some of which are low-Ca inverted pigeonite.

Many of these rocks are moderately to intensely altered, particularly those that are highly sheared. Olivine is almost always replaced by colorless amphibole or smectite and locally by red Fe oxyhydroxides. Both orthopyroxene and clinopyroxene are partially replaced by brown to brownish green amphibole and plagioclase by more sodic feldspar, epidote, or clay minerals.

\section{Oxide Gabbro and Oxide Microgabbro}

Oxide gabbros and microgabbros are best developed in Unit IV but occur as thin intervals throughout the upper $1000 \mathrm{~m}$ of the section. Many, but not all, are closely associated with zones of intense crystalplastic deformation (Shipboard Scientific Party, 1999). The oxide gabbros and microgabbros typically have sharp contacts with the enclosing 


\section{J. HERTOGEN ET AL.}

olivine gabbros, sometimes even truncating single crystals in the host rock (Ozawa et al., 1991).

Textures range from strongly foliated to granular. In the highly deformed rocks, plagioclase forms bands of minute neoblasts that enclose porphyroclasts of plagioclase, pyroxene, and less commonly olivine. The porphyroclasts are ovoid in form and typically 1-2 $\mathrm{mm}$ across. Most of the undeformed rocks are granular in texture with grain sizes ranging from 1-4 $\mathrm{mm}$ across. However, some of these display a pronounced magmatic foliation.

The oxide gabbros and microgabbros differ significantly from the other rocks in their modal mineralogy. The gabbros are characterized by relatively high modal percentages of $\mathrm{Fe}$-Ti oxides and clinopyroxene and low modal olivine and plagioclase compared to the microgabbros (Table T1). The abundance of oxide varies widely, averaging 12 modal\% in the gabbros but ranging up to as much as 50 modal\% in some samples. In undeformed rocks, the oxide occurs as relatively large (1-3 $\mathrm{mm})$ anhedral grains that partially enclose the silicate minerals. In deformed samples, it occurs as narrow, anastomosing bands and stringers parallel to the foliation, wrapping around both neoblasts and porphyroclasts. In a few cases, it also fills cracks in the silicate minerals. The oxide is ilmenite (Table T9), with an average composition of 50\% $\mathrm{TiO}_{2}, 48 \% \mathrm{FeO}, 1 \% \mathrm{MnO}$, and $0.4 \% \mathrm{MgO}$. Many of the ilmenite grains contain small globules of magmatic sulfide (Natland et al., 1991).

Based on their mineral compositions, most of these rocks are highly evolved. Plagioclase is highly variable in composition, ranging from $\mathrm{An}_{62}$ to $\mathrm{An}_{12}$ (Table T8) but has an average composition of $\mathrm{An}_{38}$ with a standard deviation of 12 (Table T4). Thus, strictly speaking, most of the rocks are diorites, even though many contain small amounts of olivine. One reason for the sodic nature of the plagioclase in these rocks is the abundance of plagioclase neoblasts in the groundmass, which are consistently more sodic (average about $\mathrm{An}_{35}$ ) than undeformed grains or porphyroclasts. In addition, many of porphyroclasts are moderately to strongly zoned with cores of about $\mathrm{An}_{50}$ and rims of $\mathrm{An}_{30-36}$ (Table T8). Bloomer et al. (1991) noted that reverse zoning occurs in some plagioclases from Unit III and the top of Unit IV. Olivine in these rocks averages about $\mathrm{FO}_{54}$ (Table T4) but like the plagioclase varies widely, ranging from $\mathrm{Fo}_{71}$ to $\mathrm{FO}_{33}$ (Table T5). Orthopyroxene averages $\mathrm{En}_{61}$ and clinopyroxene $\mathrm{En}_{41}$, with significantly less variation than either the olivine or plagioclase (Tables T4, T6, T7). Most of these rocks also have small amounts of apatite and titanite, both of which are closely associated with the oxide bands.

Most of the deformed oxide gabbros and microgabbros exhibit significant amounts of alteration. Pyroxene neoblasts and porphyroclasts are partly to completely replaced by brownish green amphibole, and olivine is partly altered to colorless amphibole. In addition, subhedral to euhedral grains of bright green amphibole are commonly associated with titanite and apatite in the oxide-rich layers and bands.

\section{Oxide Gabbronorite}

Oxide gabbronorites are very similar in texture and mineralogy to the oxide gabbros, differing only in having notably higher modal percentages of orthopyroxene (Table T1). Like the oxide gabbros, most of these rocks are deformed and have well developed foliations with bands and layers of plagioclase neoblasts enclosing porphyroclasts of plagio- 
clase, clinopyroxene, and orthopyroxene. Undeformed specimens have granular textures with grain sizes generally between 1 and $3 \mathrm{~mm}$.

An average modal composition for the oxide gabbronorites is $49 \%$ plagioclase, $1 \%$ olivine, $35 \%$ clinopyroxene, $3 \%$ orthopyroxene, $11 \%$ Fe-Ti oxide, $0.5 \%$ amphibole, $0.4 \%$ apatite, and traces of titanite (Table T1). The mineral compositions are identical to those in the oxide gabbros within one standard deviation (Table T4). In addition, the degree and nature of alteration in the oxide gabbronorites is the same as in the oxide gabbros.

\section{Downhole Variations in Mineral Compositions}

Downhole plots of mineral compositions reveal a number of significant variations, both within and between lithologic units (Figs. F3, F4, F5, F6). Olivine and clinopyroxene show similar trends in Mg\#, with a number of cyclic variations (Figs. F3, F5); orthopyroxene compositions vary in a similar fashion but the trends are much less well defined because of the paucity of data (Fig. F4). Plagioclase compositions show the widest variations, reflecting both variable degrees of deformation and alteration as well as crystal fractionation (Fig. F6). In most cases, major mineral compositional breaks correspond reasonably well to lithologic unit boundaries.

Both olivine and clinopyroxene compositions show clear cyclic variations in the lower half of the core with the minerals in each cycle generally becoming more iron rich upward (Figs. F3, F5). The first cycle extends from the base of the hole to a depth of $\sim 1270 \mathrm{mbsf}$, somewhat above the boundary between Units XII and XI. The boundary between the second and third cycles corresponds closely to the boundary between Units XI and X at 960 mbsf. The patterns become more complex in Unit $X$, with olivine becoming slightly more magnesian upward and clinopyroxene showing a bimodal distribution. Unit X consists of interlayered gabbro and olivine gabbro, and the bimodal distribution of the clinopyroxene suggests the presence of two parental melts. There is a gap in the data between $\sim 825$ and $750 \mathrm{mbsf}$, but it appears that the third cycle extends to the top of Unit IX at 714 mbsf. Despite the cyclic variations described above, both olivine and clinopyroxene show a clear upward decrease in $\mathrm{Mg} \#$ in the lower half of the core.

Plagioclase compositions follow a similar pattern in the lower part of the core, although the cycles are not as clearly defined (Fig. F6). The most pronounced break in the sequence is at the boundary of Units XI and $\mathrm{X}$, where one of the cycles begins. There are three zones of very sodic plagioclase $\left(>\mathrm{An}_{20}\right)$ and these correspond closely to the more evolved olivine and pyroxene compositions. Thus, they are interpreted as primary features rather than as the result of deformation and alteration.

Mineral compositions in the upper half of the core are much more varied and complex than in the lower part. There are no data for Unit VIII and only very limited pyroxene and plagioclase data for Unit VII. Unit VI, which consists of olivine gabbro and troctolite, is the most primitive in the entire core, with olivine compositions as high as $\mathrm{Fo}_{87}$ and plagioclase as high as $\mathrm{An}_{80}$. The plagioclase in this unit is quite varied, and the very sodic compositions near the base of the unit are due to alteration and deformation. Unit $\mathrm{V}$ has slightly more evolved mineral compositions than Unit VI, although overall, the minerals are much more uniform. 
Unit IV is composed of highly evolved Fe-Ti oxide gabbro and has very iron-rich olivine (as low as $\mathrm{Fo}_{30}$ ) and pyroxene and very sodic plagioclase (mostly less than $\mathrm{An}_{40}$ ). Unit III consists of olivine gabbro but is much more evolved than any of the olivine gabbros lower in the section (Figs. F3, F4, F5, F6).

Mineral compositions in lithologic Unit II are some of the most interesting in the section. This unit consists primarily of olivine gabbro and olivine-bearing gabbro but has a number of thin bands of Fe-Ti oxide gabbro, commonly associated with shear zones. This results in a strong bimodal distribution of plagioclase and a similar, but less pronounced, pattern for clinopyroxene. Because olivine is rare in the oxide gabbros, it is much more uniform in composition, but a few grains have compositions below $\mathrm{Fo}_{60}$. Unit I consists largely of metagabbro and almost no primary minerals are preserved.

\section{GEOCHEMISTRY}

\section{Analytical Techniques}

Table T10 is a compilation of shipboard and shore-based geochemical analyses for samples from Legs 118 and 176. Shore-based data for Leg 118 samples (0-500.7 mbsf) were obtained at Justus-Liebig Universität, Giessen, Germany (labeled "G" in Table T10), whereas those for Leg 176 samples (500.7-1500.8 mbsf) were generated at the GeoForschungsZentrum, Potsdam, Germany (labeled " $\mathrm{P}$ " in Table T10). Additional shore-based data were obtained at the Katholieke Universiteit Leuven, Belgium, and these are labeled " $L$ " in Table T10. Those samples labeled "GL" in Table T10 indicate that the rare earth element (REE), $\mathrm{Hf}, \mathrm{Ta}$, Th, and $\mathrm{U}$, analyses were carried out at Leuven, whereas the remaining data are from Giessen. During Leg 176, 186 samples were analyzed aboard ship for major oxides and the trace elements $\mathrm{V}, \mathrm{Cr}, \mathrm{Ni}, \mathrm{Cu}$, $\mathrm{Zn}, \mathrm{Rb}, \mathrm{Sr}, \mathrm{Y}, \mathrm{Zr}$, and $\mathrm{Nb}$. Of these, 180 were from the Leg 176 core (labeled "S" in Table T10) and 6 were from the lower $50 \mathrm{~m}$ of Leg 118 core (labeled "H" in Table T10).

Samples taken for shipboard analysis generally weighed between 20 and $30 \mathrm{~g}$, but a few larger samples were taken from very coarse grained rocks. After coarse crushing, the samples were ground in an agate mor$\operatorname{tar}$ (Leg 118) or in a tungsten carbide shatterbox (Leg 176). The powders were dried at $110^{\circ} \mathrm{C}$ and then ignited at $1010^{\circ} \mathrm{C}$ for several hours to determine the loss on ignition. $600 \mathrm{mg}$ of ignited rock powder was then mixed with a fusion flux consisting of $80 \mathrm{wt} \%$ lithium tetraborate and $20 \mathrm{wt} \% \mathrm{La}_{2} \mathrm{O}_{3}$. This mixture was then melted in a platinum mold to form a glass bead for major element analysis. Trace element analyses were carried out on pressed powder pellets prepared from $5 \mathrm{~g}$ of rock powder dried at $110^{\circ} \mathrm{C}$. All analyses were carried out using the shipboard ARL 8420 wavelength-dispersive X-ray fluorescence (XRF) equipment. Full details of the analytical procedures can be found in Shipboard Scientific Party (1989). For major oxides, analytical error is $<0.6$ relative percent except for $\mathrm{Na}_{2} \mathrm{O}$ which has an error of 3.8 relative percent. For trace elements, the analytical error is $<1.5$ relative percent except for $\mathrm{Rb}(3.6 \%)$, and $\mathrm{V}(2.0 \%)$. After the Leg 176 cruise, all the shipboard samples were analyzed for ferrous iron at Leuven using the redox titration method of Shafter (1996).

A total of 220 samples from Leg 118 were analyzed for major and trace elements at Giessen, and 43 samples from Leg 176 were analyzed
T10. Geochemical database for shipboard and shore-based analyses of samples, p. 80. 


\section{J. HERTOGEN ET AL.}

in Potsdam. Major element oxides were analyzed by XRF on samples prepared as fused disks of lithium metaborate (sample-to-flux ratio of 1:4 and 1:6 for "G" and "P" samples, respectively). Philips PW 1400 and Siemens SRS 303 AS computerized X-ray spectrometers were used, and commercial Philips and Siemens "alphas" programs calculated the concentrations. Ferrous iron was determined by manganometric titration (" $\mathrm{G}$ ") and potentiometric titration according to Wilson's method ("P"). $\mathrm{H}_{2} \mathrm{O}+$ analyses were performed by coulometric Karl-Fischer titration after thermal decomposition of the samples at $1200^{\circ} \mathrm{C}($ " $\mathrm{G}$ ") and with a LECO analyzer RC-412 ("P"). $\mathrm{CO}_{2}$ was measured coulometrically following decomposition at $1200^{\circ} \mathrm{C}$ ("G") and using a LECO RC-412 analyzer $(" \mathrm{P}$ "). Sulfur analyses were performed using LECO sulfur determinators SC 132 ("G") and CS 225 ("P"). Fluorine was analyzed with a fluoridesensitive electrode, following a pyrohydrolytic decomposition method (Erzinger and Puchelt, 1982).

Determinations of $\mathrm{Ba}, \mathrm{Co}, \mathrm{Cr}, \mathrm{Cu}, \mathrm{Ga}, \mathrm{Nb}, \mathrm{Ni}, \mathrm{Zn}, \mathrm{Sr}, \mathrm{Y}, \mathrm{V}, \mathrm{Zn}$, and $\mathrm{Zr}$ were conducted by XRF on pressed powder pellets. The rhodium Compton peak of the X-ray tube was used for matrix corrections. Numerous international reference rocks were used for calibration of the XRF methods.

The REE were determined by optical emission spectrometry (OES) using an inductively coupled argon plasma for excitation (ICP-OES), following $\mathrm{Na}_{2} \mathrm{O}_{2}$ fusion and a chromatographic separation and concentration procedure. A detailed description of the method is given by Zuleger and Erzinger (1988).

Previous studies in our laboratory (e.g., on Hole 504B rocks) revealed that chemical data sets from various laboratories differ significantly because of different analytical accuracy and precision (see Boström and Bach, 1995, for a discussion). Therefore, we carefully tested our data with the reference data from Govindaraju (1994) and with data from other laboratories to ensure proper analytical accuracy. The precision of major and trace element determination was tested by multiple measurements on selected samples. The accuracy and precision were checked by carrying the international reference rocks BHVO-1 ("G"), BM ("P"), and the Leg 140 interlaboratory standard Bas 140 ("G") (Sparks and Zuleger, 1995) as unknowns through the whole procedure. The chemical results are given in Table T11 along with the analytical errors and recommended concentration values.

Assuming the analytical error is close to twice the standard deviation, the precision for the major elements is better than 1.5 relative percent and the precision for the trace elements is better than 10 relative percent, mostly better than 5. Further details on analytical accuracy and precision of the data are given in Bach et al. (1996) and Zuleger et al. $(1996,1995)$.

The samples analyzed at Leuven for major and trace elements were crushed and ground in agate mortars. Thus, neither Co nor Ta was affected by contamination from tungsten carbide.

For determination of the major elements at Leuven, $100 \mathrm{mg}$ of sample powder was fused with $0.5 \mathrm{~g}$ Li metaborate in a graphite crucible by heating in a muffle furnace. The fused glass was then dissolved in dilute nitric acid. The concentrations of the elements $\mathrm{Si}, \mathrm{Al}, \mathrm{Ti}, \mathrm{Fe}, \mathrm{Mg}, \mathrm{Ca}$, and $\mathrm{P}$ were measured using a direct-current plasma atomic emission spectrometer (DCP-AES) (Bankston et al., 1979). The alkali elements $\mathrm{Na}$ and $\mathrm{K}$ were analyzed by flame atomization atomic absorption spectrometry (AAS). The analytical precision of the major elements is estimated
T11. Major and trace element data for reference rocks BM, BHVO-1, and ODP Bas 140, p. 81. 
at $2 \%-3 \%$ (relative) for the elements $\mathrm{Si}, \mathrm{Al}, \mathrm{Fe}, \mathrm{Mg}, \mathrm{Ca}$, and $\mathrm{Na}$. Precision for the minor elements $\mathrm{Ti}, \mathrm{Mn}$, and $\mathrm{K}$ varies from $5 \%$ to $15 \%$ (relative) depending upon their concentration.

The trace elements Sc, Cr, Co, REE, Hf, Ta, Th, and U were determined by INAA using $800 \mathrm{mg}$ of sample powder. Samples were irradiated in the Thetis reactor of Ghent University, Belgium. The induced gamma ray activities were measured at Leuven using extra-high-resolution small and large Ge detectors. For details of the procedure and of the accuracy and precision obtained, see Hertogen and Gijbels (1981) and Pedersen and Hertogen (1990). The samples were analyzed relative to a secondary in-house standard rock that has been repeatedly calibrated against international reference rocks. The analytical precision of the trace elements is variable; generally better than $5 \%$ (relative) for Sc, $\mathrm{Cr}$, Co, $\mathrm{Sm}$, and $\mathrm{Eu}$, between $5 \%$ and $10 \%$ for $\mathrm{La}, \mathrm{Tb}, \mathrm{Yb}$, and $\mathrm{Hf}$, and between $5 \%$ and $25 \%$ for $\mathrm{Ce}, \mathrm{Nd}, \mathrm{Lu}$, and $\mathrm{Ta}$, depending on their concentration.

\section{Analytical Results}

Table T10 summarizes the chemical compositions of the 451 rock samples analyzed for this study. The values for $\mathrm{Rb}$ and $\mathrm{Nb}(<5 \mathrm{ppm})$ and $\mathrm{Ba}(<20 \mathrm{ppm})$ were below the detection limit of the methods used and are not reported. In the XRF analyses, total iron is expressed as $\mathrm{Fe}_{2} \mathrm{O}_{3} \mathrm{t}$. For all shore-based analyses, $\mathrm{FeO}$ was determined independently and is reported in Table T10. Two calculated values for the $\mathrm{Mg \#}\left(100 \mathrm{Mg}^{+2} /\right.$ $\left.\left[\mathrm{Mg}^{+2}+\mathrm{Fe}^{+2}\right]\right)$ are also given in Table T10. Where FeO was determined independently, the analyzed value was used in the calculation. Where only $\mathrm{Fe}_{2} \mathrm{O}_{3} \mathrm{t}$ is available, $\mathrm{Mg \# s}$ were calculated by taking $80 \%$ of the total iron as FeO. Shipboard calculations of Mg\#s assumed $\mathrm{FeO}$ to be $85 \%$ of total iron, but we found that a value of $80 \%$ better replicates the Mg\#s produced for samples in which $\mathrm{FeO}$ was determined independently.

Table T12 presents the average chemical composition of each lithologic unit based on the data in Table T10. Where data are missing for some samples (e.g., V), the averages were recalculated to take into account the missing values.

\section{Downhole Variations in Geochemistry}

Downhole variations in bulk rock chemistry are presented in the figures described in the following sections to illustrate the chemical variability of the rocks in Hole 735B.

\section{Major Oxides}

$\mathrm{SiO}_{2}$ is relatively constant downhole, averaging just over $50 \mathrm{wt} \%$ (Fig. F7). The largest variations occur in lithologic Unit IV, which consists of Fe-Ti oxide-rich gabbro, and Unit VI, which consists of interlayered olivine gabbro and troctolite. The other analyses that deviate significantly from the average reflect mostly alteration or the addition of silicic material in the sample. There is very little scatter of points in the lowest $500 \mathrm{~m}$ of the core where the rocks are very fresh.

$\mathrm{Al}_{2} \mathrm{O}_{3}$ shows much greater downhole variability than $\mathrm{SiO}_{2}$ but with a very slight increase in the average abundance with depth (Fig. F8). Again, Units IV and VI deviate the most from the average value because they have the most extreme compositions. Because plagioclase is the
T12. Average chemical compositions of lithologic units, p. 82.

F7. Downhole variation of $\mathrm{SiO}_{2}$, p. 34 .

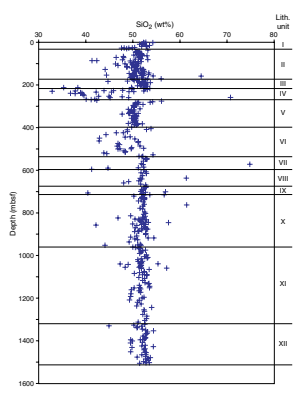

F8. Downhole variation of $\mathrm{Al}_{2} \mathrm{O}_{3}$, p. 35 .

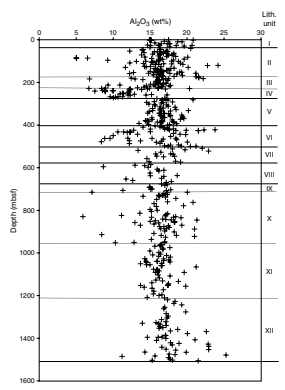


major $\mathrm{Al}_{2} \mathrm{O}_{3}$-bearing phase, the scatter in $\mathrm{Al}_{2} \mathrm{O}_{3}$ reflects small-scale variations in plagioclase abundance and composition. Also, plagioclase is susceptible to variable degrees of alteration, which affect the bulk-rock geochemistry.

$\mathrm{Fe}_{2} \mathrm{O}_{3} \mathrm{t}$ and $\mathrm{TiO}_{2}$ vary in a sympathetic fashion downhole, increasing markedly in Units IV and VI (Figs. F9, F10). To be consistent, the $\mathrm{Fe}_{2} \mathrm{O}_{3} \mathrm{t}$ plot includes both calculated $\left(\mathrm{Fe}_{2} \mathrm{O}_{3}+\mathrm{FeO} \times 1.111\right)$ and measured values. Positive spikes reflect primarily thin bands of oxide gabbro commonly associated with narrow shear zones. Note that the average values of $\mathrm{TiO}_{2}$ decrease very slightly downward in Unit $\mathrm{V}$ and from the top of Unit VII to the bottom of the hole.

$\mathrm{MnO}$ shows limited variation in the hole and varies sympathetically with $\mathrm{Fe}_{2} \mathrm{O}_{3}$ t (Fig. F11). There is a significant increase in Units III and IV and a number of small spikes lower in the hole corresponding to Fe-Ti oxide-rich bands. $\mathrm{MnO}$ is relatively constant below the top of Unit VII, and like $\mathrm{TiO}_{2}$, the average $\mathrm{MnO}$ value shows a slight downward decrease from this point.

$\mathrm{MgO}$ values vary widely, both within and between individual lithologic units (Fig. F12). For example, in Unit II MgO contents range from 4 to $\sim 23 \mathrm{wt} \%$ and in Unit $\mathrm{X}$ from 2 to $\sim 23 \mathrm{wt} \%$. These variations appear to reflect both lithologic character and degrees of alteration. The lowest average values are in Unit IV, composed largely of Fe-Ti oxide gabbro, and the highest average values are in the olivine gabbros and troctolites. There appear to be distinct compositional breaks in $\mathrm{MgO}$ content at 1160 mbsf in Unit XI and at the upper and lower contacts of Unit IV.

Figures F13 and F14 are both plots of Mg\#s. Figure F13 contains data only for those samples in which $\mathrm{FeO}$ was actually measured, whereas Figure F14 $(\mathrm{Mg} \#=80)$ presents Mg\#s calculated by assigning $80 \%$ of the $\mathrm{Fe}_{2} \mathrm{O}_{3} \mathrm{t}$ as FeO. Mg\#s reported in the shipboard report (Shipboard Scientific Party, 1999) were calculated based on the assumption that $\mathrm{FeO}$ was equal to $85 \%$ of $\mathrm{Fe}_{2} \mathrm{O}_{3} \mathrm{t}$, but we find that our calculations correspond more closely to those in which $\mathrm{FeO}$ was determined independently. Using a value for $\mathrm{FeO}$ of $80 \%$, rather than $85 \%$ of total iron, doesn't change the shape of the plot; it merely shifts everything uniformly to higher numbers. The relatively high proportion of $\mathrm{Fe}_{2} \mathrm{O}_{3}$ in these rocks probably reflects local secondary oxidation.

The Mg\#s show considerable variation downhole commonly with distinct breaks at lithologic unit boundaries. For example, Unit XII shows a small upward decrease in Mg\#s from $\sim 82$ at the base to 75 at the top with a few values even lower. At the base of Unit XI, Mg\#s shift to slightly higher values and then decrease upward very much like those in Unit XII. Values in Unit X are more scattered but again are highest at the base and decrease somewhat upward, particularly near the top of the unit. The distinctly low values in all the units correspond to Fe-Ti oxide bands or to felsic units within the host rock. Units IX and $\mathrm{X}$ also show some distinctly low Mg\#s, but no overall trends are apparent. Unit VII has only a few values, but they appear to decrease upward. A distinctly different pattern is apparent in Unit VI where there is an upward trend to higher numbers. Unit $\mathrm{V}$ is characterized by a tight cluster of values, which again show a marked upward decrease from $\sim 84$ at the base to 76 at the top. As expected, Unit IV, rich in Fe-Ti oxide gabbro, has the lowest average value in the hole and is characterized by sharp breaks in composition at both the upper and lower contacts. Unit III has two separate clusters of values, one at $\sim 85$ and the other at $\sim 70$.
F9. Downhole variation of $\mathrm{TiO}_{2}$, p. 36.

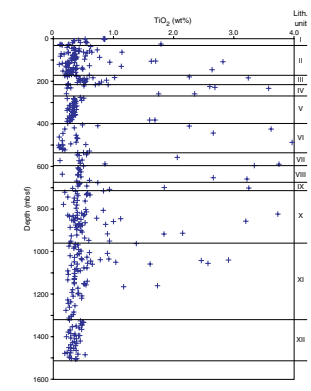

F10. Downhole variation of $\mathrm{Fe}_{2} \mathrm{O}_{3 \text { total, }}$ p. 37 .

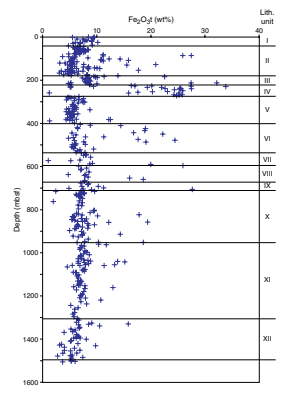

F11. Downhole variation of $\mathrm{MnO}$, p. 38.

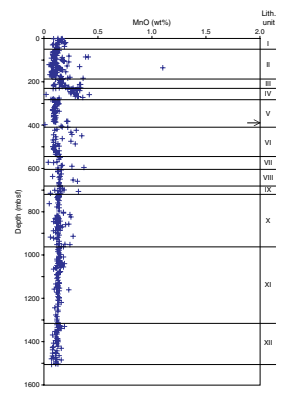


Again, there is a sharp break in composition at the boundary between Units II and III. Although there is some scatter in Unit II, most values cluster around 81-82 with a small decrease in the upper 15-20 m. Unit I has a cluster of values between $\sim 63$ and 72 and another smaller one between 80 and 82 .

Overall, there is a small increase in Mg\#s downward in the lower part of the hole, particularly in Units X, XI, and XII, as the rocks become more olivine rich with depth. The cyclic nature of the variations in Mg\#s, particularly the upward decrease in some units, has been interpreted as reflecting fractionation of several distinct magma bodies (Shipboard Scientific Party, 1999; Dick, Natland, Miller, et al., 1999).

Both $\mathrm{CaO}$ and $\mathrm{Na}_{2} \mathrm{O}$ exhibit considerable scatter in the upper parts of the hole but become more uniform at depth (Figs. F15, F16). The abundance and composition of plagioclase are the main controls on $\mathrm{CaO}$ and $\mathrm{Na}_{2} \mathrm{O}$, and the relative proportions are highly sensitive to zoning and alteration. As expected, the downhole trends are nearly mirror images of one another. This is particularly noticeable in Units II, III, IV, and $\mathrm{V}$. In the lower part of the hole, from approximately the top of Unit VII to the base of Unit XII, there is a small increase in the average content of $\mathrm{CaO}$ and a corresponding decrease in $\mathrm{Na}_{2} \mathrm{O}$.

$\mathrm{K}_{2} \mathrm{O}$ is relatively uniform in the hole with a very small downward decrease in abundance (Fig. F17). The $\mathrm{K}_{2} \mathrm{O}$ resides largely in alkali feldspar and mica, and the few relatively high values correspond to felsic patches which contain both minerals.

Apatite is the only significant phosphorous-bearing mineral in Hole 735B and its occurrence is closely related the Fe-Ti oxide gabbros. Background levels of $\mathrm{P}_{2} \mathrm{O}_{5}$ are very low $(<0.1 \mathrm{wt} \%)$ (Fig. F18), and the few spikes correspond to oxide-rich bands.

$\mathrm{H}_{2} \mathrm{O}$ was measured on only 10 shipboard samples, so there are relatively few data available for the lower part of the hole (Fig. F19). In the upper part of the hole to $\sim 400 \mathrm{mbsf}$, there is a steady decrease in the average water content, reflecting the downward decrease in metamorphism and alteration. The few high values in the lower parts of the hole reflect local zones of alteration.

As with $\mathrm{H}_{2} \mathrm{O}$, most of the data for $\mathrm{CO}_{2}$ and $\mathrm{S}$ are from the upper 500 $\mathrm{m}$ of the hole. $\mathrm{CO}_{2}$ has a narrow range of composition, with only two samples having $>1 \mathrm{wt} \%$ (Fig. F20). The actual amounts are probably somewhat higher because most of the samples were selected to avoid veins and highly altered zones. It is clear, however, that the background level is relatively low and constant at $\sim 0.1 \mathrm{wt} \%$ (Fig. F20). The few higher values reflect the introduction of carbonate along small cracks and fractures. $\mathrm{S}$ contents in most of the rocks are also low (generally $<0.1 \mathrm{wt} \%)$. However, S is significantly enriched in Unit IV, which consists of Fe-Ti oxide gabbro (Fig. F21). This accords with the common presence of minute amounts of pyrite and sulfides in the Fe-Ti oxiderich gabbros. The other spikes in S content shown in Fig. F21 also correlate with Fe-Ti oxide-rich zones.

\section{Trace Elements}

Vanadium has a relatively constant background concentration of $\sim 150 \mathrm{ppm}$ in gabbros and olivine gabbros but increases significantly in the Fe-Ti oxide gabbros. Thus, Unit IV has strong $\mathrm{V}$ enrichment with most values between 300 and $1300 \mathrm{ppm}$ and one value above 2000 ppm (Fig. F22). Similar scattered high values in the other lithologic
F12. Downhole variation of $\mathrm{MgO}$, p. 39.

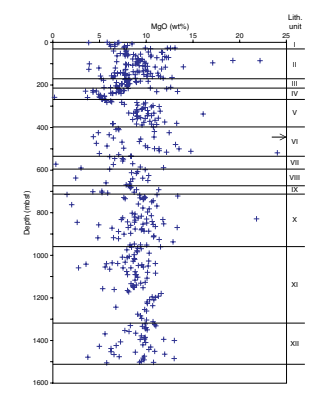

F13. Downhole variation of Mg\#, p. 40 .

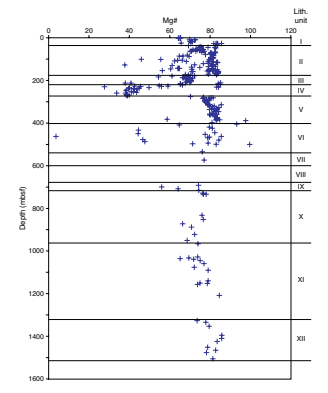

F14. Downhole variation of Mg\#80, p. 41.

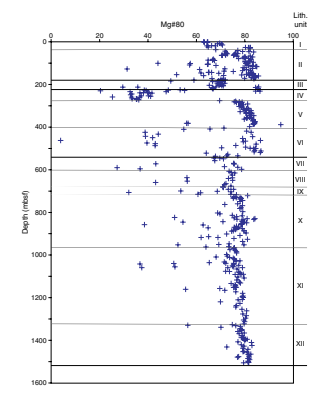

F15. Downhole variation of $\mathrm{CaO}$, p. 42.

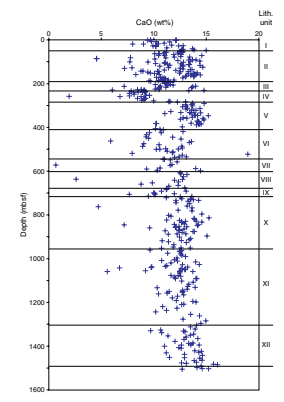




\section{J. HERTOGEN ET AL. \\ Lithology, Mineralogy, ANd Geochemistry of The LoWer OCEAN Crust}

units correlate with thin bands of Fe-Ti oxide gabbro. As expected, $\mathrm{V}$ contents correlate well with variations in $\mathrm{TiO}_{2}$.

Ni resides mostly in olivine with only minor amounts in pentlandite. Thus, Ni contents vary significantly downhole with maximum values (900 ppm) in Unit VI (olivine gabbro and troctolite) and minimum values in Unit IV (Fe-Ti oxide gabbro). Elsewhere in the core, Ni contents generally lie between $\sim 50$ and 200 ppm but show significant scatter. A distinct break in Ni contents occurs at 1240 mbsf in Unit XI and at several lithologic unit boundaries (Fig. F23).

In Hole 735B, Cr resides chiefly in clinopyroxene and thus varies significantly downhole. $\mathrm{Cr}$ contents are particularly high and variable in the upper $550 \mathrm{~m}$ (Units I-VI), ranging up to $1000 \mathrm{ppm}$ (Fig. F24). In the lower part of the hole, Cr contents are mostly $<400 \mathrm{ppm}$, although they still exhibit considerable variability. Unit XI exhibits an unusual pattern with relatively high and scattered values at the base and very low, tightly clustered values at the top (Fig. F24). There are distinct boundaries in Cr contents between several lithologic units, particularly between Units IV and V, IX and X, and X and XI.

Zn contents in Hole 735B rocks are generally low, with most values between 10 and $50 \mathrm{ppm}$. However, a number of higher values (up to $260 \mathrm{ppm}$ ) are present locally, and these correlate with zones of Fe-Ti oxide gabbro. This correlation is well illustrated in Unit IV, where $\mathrm{Zn}$ values range from 100 to $260 \mathrm{ppm}$ (Fig. F25). The other Zn spikes likewise correlate with thin bands of Fe-Ti oxide gabbro scattered through the core. Values are very consistent in Unit V but show a slight downward decrease. A small increase occurs at the top of Unit VI, and the average $\mathrm{Zn}$ values increase to the base of Unit VIII. Below this level, the background level is relatively constant ( 40 ppm) to a depth of $1090 \mathrm{mbsf}$ within Unit $X$, at which point it decreases to $\sim 30 \mathrm{ppm}$ and then increases again to $60 \mathrm{ppm}$ at $1150 \mathrm{mbsf}$. The average value then decreases regularly to $\sim 20 \mathrm{ppm}$ at the base of the hole.

Copper is relatively low in Units I and II (generally $<70 \mathrm{ppm}$ ) and highly variable in Unit III (Fig. F26). There are no obvious trends in the remainder of the hole. Although individual values are quite variable, the average value is $\sim 80 \mathrm{ppm}$.

As incompatible elements, $\mathrm{Y}$ and $\mathrm{Zr}$ have similar downhole trends (Figs. F27, F28). Background levels are low for both elements (10-15 ppm), and both show relatively little scatter. Units IV, VI, VII, IX, and X have increased values for both elements (up to $150 \mathrm{ppm} \mathrm{Y}$ and $600 \mathrm{ppm}$ $\mathrm{Zr}$ ). These units have somewhat higher percentages of felsic material containing rare crystals of zircon. There is also a significant spike in both elements in Unit XI at 1040 mbsf, which correlates with a zone of Fe-Ti oxide gabbro.

Strontium varies widely downhole, from $\sim 15$ to $260 \mathrm{ppm}$, but exhibits no obvious trends (Fig. F29). It resides primarily in plagioclase and correlates reasonably well with $\mathrm{CaO}$.

\section{REE Geochemistry}

The downhole variation of Sm is shown in Figure F30. The Sm content is a good measure of the overall REE concentration levels. The sampling density within the upper part of Hole 735B is rather high, and the analyzed samples probably cover the whole concentration range.

The total variation of absolute REE contents is quite high and is accompanied by rather large fractionation of light (LREE) from heavy (HREE) rare earth elements. This is illustrated by the downhole varia-
F16. Downhole variation of $\mathrm{Na}_{2} \mathrm{O}$, p. 43.

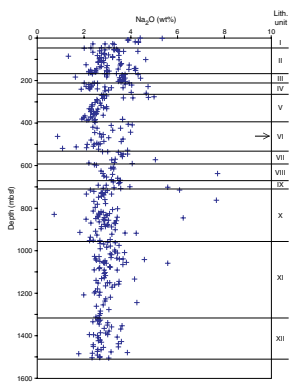

F17. Downhole variation of $\mathrm{K}_{2} \mathrm{O}$, p. 44 .

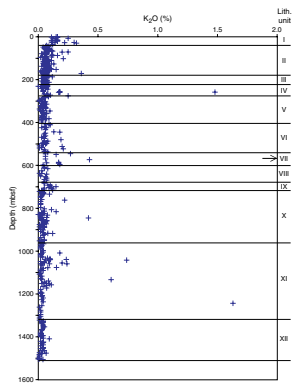

F18. Downhole variation of $\mathrm{P}_{2} \mathrm{O}_{5}$, p. 45 .

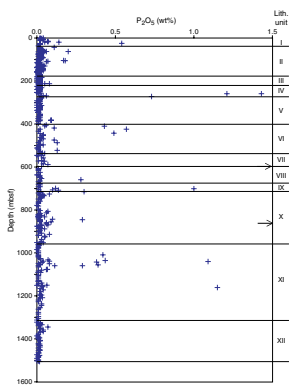

F19. Downhole variation of $\mathrm{H}_{2} \mathrm{O}$, p. 46 .

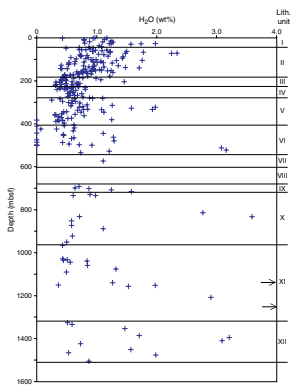


tion of chondrite-normalized $\mathrm{La} / \mathrm{Yb}$ ratios (Fig. F31). The majority of the samples have normalized $\mathrm{La} / \mathrm{Yb}$ ratios less than unity, a feature that the gabbroic rocks inherited from their LREE-depleted parental melts.

Figure F32 shows the chondrite-normalized REE patterns of representative Leg 176 samples. This sample subset illustrates the overall variation of the REE content and the shapes of the REE patterns in Hole 735B rocks. The lowest REE concentrations occur in the troctolitic rocks, which are characterized by low abundances (due to a low fraction of trapped liquid component), relatively flat chondrite-normalized patterns (due to low clinopyroxene content), and pronounced positive Eu anomalies (due to selective uptake of $\mathrm{Eu}^{+2}$ in anorthite).

Variations of REE abundances in the gabbroic (senso stricto) rocks reflect the variable amounts of trapped intercumulus liquids. The trapped parental liquid, which does not have a significant Eu anomaly, smooths the positive $\mathrm{Eu}$ anomalies of plagioclase and the low $\mathrm{La} / \mathrm{Yb}$ ratios typical of clinopyroxene.

A number of the Hole 735B samples show a pronounced overall enrichment of REE. The majority of these samples are enriched in a strongly fractionated, plagiogranitic residual component (melt or fluid). Because of the very high REE content, these residual liquids are important components in the REE mass balance of the gabbroic section, in spite of the low volumetric contribution these rocks make to the plutonic pile.

The overall REE geochemistry is summarized in Figure F33 ( $\mathrm{La} / \mathrm{Yb}$ vs. $\mathrm{Yb}$ ). For more details on this type of diagram, see also Barling et al. (1997). The REE content of a large fraction of the samples can be explained by a three component mixing of cumulus plagioclase (high La/ $\mathrm{Yb}$ and low HREE), cumulus clinopyroxene (low La/Yb and higher HREE), and relatively unfractionated trapped melt. Most of the samples seem to converge to a liquid composition similar to the composition of the diabase dikes cored in the upper part of Hole 735B (e.g., Samples 176-735B-23R-4, $66 \mathrm{~cm}$, to 23R-5, $21 \mathrm{~cm}$ ). This suggests that these diabases may be fairly representative of the parental magma of the Hole 735B plutonic pile and that the parental magmas were rather uniform in composition. The oxide-rich gabbros are mainly positioned in the lower right quadrant of the figure as expected from their formation from more evolved liquids having a higher $\mathrm{Yb}$ content.

\section{SUMMARY AND DISCUSSION}

Hole 735B provides a nearly complete 1508 -m section of the lower ocean crust generated at the Southwest Indian Ridge at $11.5 \mathrm{Ma}$. The block underlying Atlantis Bank is anomalous in that it has been unroofed and uplifted to shallow levels; however, it consists of rocks whose seismic velocities and physical properties are appropriate for oceanic Layer 3 (Iturrino et al., 1991; Dick, Natland, Miller, et al., 1999). Although the section is cut by a number of ductile shear zones and at least one major fault, it appears to be relatively coherent. Thus, it provides a unique opportunity to investigate the physical and magmatic processes involved in formation of the lower ocean crust at an ultraslow-spreading ridge.

A total of 952 lithologic intervals, bounded by igneous or tectonic contacts, were recognized by the Leg 118 and 176 shipboard parties and Dick et al. (1991b). These were grouped into 12 major lithologic units, based primarily on modal mineralogy. Unit I, however, was defined on
F20. Downhole variation of $\mathrm{CO}_{2}$, p. 47.

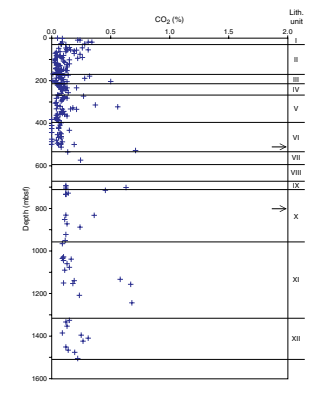

F21. Downhole variation of $S$, p. 48 .

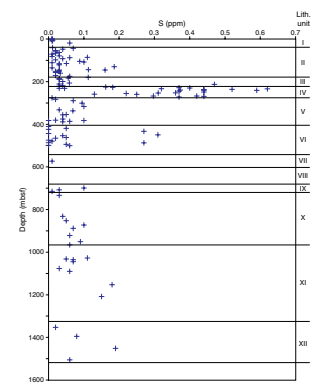

F22. Downhole variation of $\mathrm{V}$, p. 49.

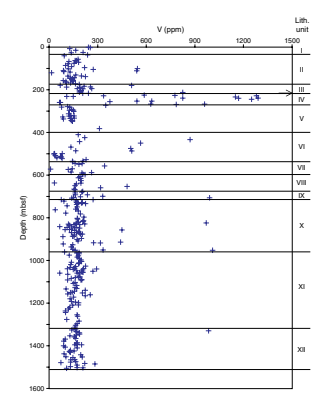

F23. Downhole variation of $\mathrm{Ni}$, p. 50.

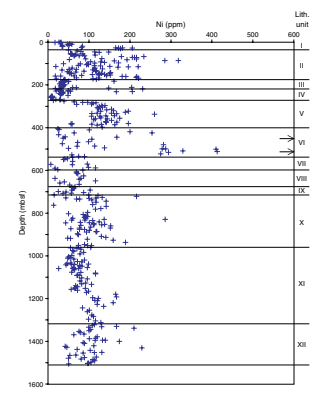


the basis of extensive crystal-plastic deformation and metamorphism. Highly deformed gabbros similar to those of Unit I occur extensively on the top of Atlantis Bank (MacLeod et al., 1998) and are considered to mark the detachment fault that unroofed the block.

The bulk of the cored section consists of relatively primitive olivine gabbro, troctolite, and troctolitic gabbro. These rocks are intruded by a variety of more evolved gabbros, gabbronorites and oxide-bearing and oxide-rich gabbros and gabbronorites. Most of the oxide-bearing and oxide-rich intervals are relatively thin, generally no more than a few centimeters thick. However, in lithologic Unit IV, defined on its abundance of oxide-bearing rocks, there are 28 intervals of oxide-bearing and oxide-rich gabbro and gabbronorite with an average thickness of $1.76 \mathrm{~m}$ (Natland and Dick, Synthesis Chapter, this volume).

Because the lithologic units were defined on a variety of criteria, they have limited genetic significance. However, downhole plots of mineral compositions and bulk-rock geochemistry reveal a number of correlations of these parameters with the lithologic units. Such correlations are most apparent in downhole plots of $\mathrm{Mg} \#$ for clinopyroxene, An content of plagioclase, bulk-rock $\mathrm{TiO}_{2}$ contents, and bulk-rock Mg\#. Plagioclase compositions and bulk-rock Mg\#s must be interpreted with care because the former are very sensitive to alteration and the latter to the presence of Fe-Ti oxides. However, Mg\#s for clinopyroxene (Fig. F5) correlate well with most lithologic units and exhibit similar trends within many units. In lithologic Units XII, XI, IX, VI, and V the clinopyroxene $\mathrm{Mg \#}$ is highest at the base and decreases gradually upward. Unit IV exhibits a reverse trend, going from low Mg\#s at the base to higher values at the top. Regular trends are not apparent in the other units.

Similar, but less well-defined trends are observed for An contents of plagioclase (Fig. F6). In several lithologic units, particularly Units I through $\mathrm{V}$, plagioclase compositions have a bimodal distribution, reflecting extensive alteration and metamorphism.

Olivine compositions are more variable, but some trends are apparent, particularly in the lower part of the hole. In lithologic Units XII, $\mathrm{XI}, \mathrm{X}$, and IX, olivine compositions generally become more iron rich upward within each unit and within the sequence as a whole (Fig. F3). Olivine compositions are more variable in the upper part of the sequence, reflecting the intrusion of relatively evolved oxide and oxidebearing gabbros and gabbronorites. Similar patterns are shown by orthopyroxene compositions, although the number of analyses is much lower (Fig. F4).

The Leg 176 Shipboard Party (1999), Dick et al. (2000), and Robinson et al. (2000) recognized five major geochemical cycles in the 1508-m section based largely on whole-rock Mg\#s and interpreted the cycles to reflect the intrusion of five separate plutons. Upon reviewing all of the postcruise geochemical and mineralogical data, Natland and Dick (Synthesis Chapter, this volume) recognize three geochemical series within the gabbros, olivine gabbros, and troctolites, which extend from 0-232, 274-520, and 520-1507 mbsf, respectively. The gap between $232 \mathrm{mbsf}$ and $274 \mathrm{mbsf}$ is marked by the oxide and oxide-bearing gabbros of lithologic Unit IV. Natland and Dick (Synthesis Chapter, this volume) divided Series III into three subunits: 520-962, 962-194, and 11941508 mbsf, labeled 3a, 3b, and 3c, respectively. These are close to the lower three geochemical cycles recognized by Dick et al. (2000) and Robinson et al. (2000) but with slight changes in the positions of the boundaries. This does not represent a major reinterpretation of the geochemical stratigraphy but rather a re-evaluation of the significance
F24. Downhole variation of $\mathrm{Cr}$, p. 51 .

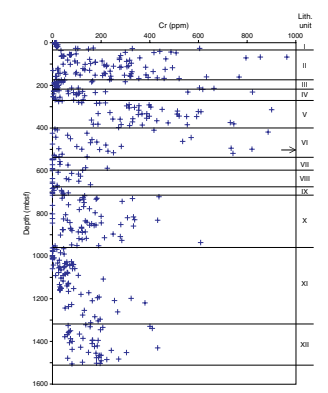

F25. Downhole variation of $\mathrm{Zn}$, p. 52 .

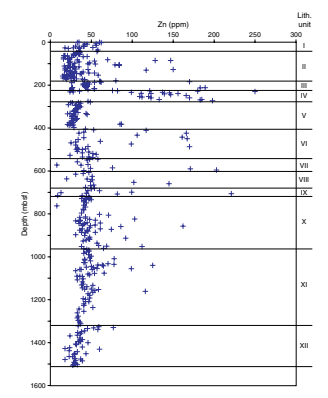

F26. Downhole variation of $\mathrm{Cu}$, p. 53.

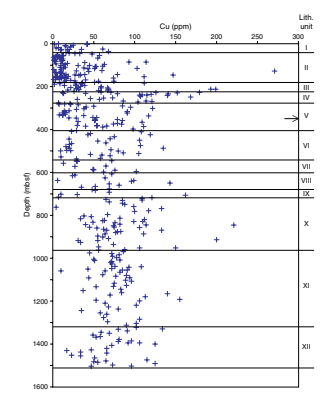

F27. Downhole variation of $Y$, p. 54 .

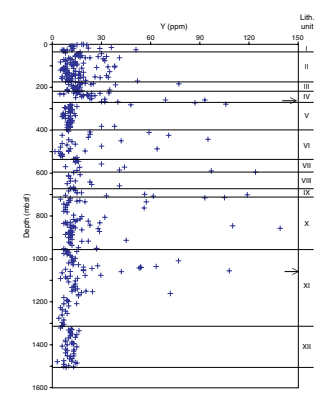


of the lower three cycles. Whether these cycles represent individual plutons or repeated pulses of magma into a single magma chamber is a matter of interpretation. However, the overall geochemical coherence of these three cycles supports the latter interpretation.

It is clear from the downhole plot of whole-rock Mg\#s (Fig. F14) that the most primitive olivine gabbros and troctolites occur in the upper parts of the section where they comprise geochemical cycles 1 and 2 (Series 1 and 2 of Natland and Dick, Synthesis Chapter, this volume). In both cases, the most primitive rocks occur at the base of the cycle and the most evolved rocks at the top with Mg\#s decreasing progressively upward. We interpret each of these cycles as representing a magmatic intrusion that underwent fractionation in place. Natland and Dick (Synthesis Chapter, this volume) suggest that the small-scale variations within these cycles indicate that these plutons were constructed from numerous individual injections rather than large pulses of magma, an interpretation consistent with the general absence of layering within the sequence. However, if this was the case, the pulses must have come from a fractionating body at greater depth to account for the smooth upward trend within each cycle.

The long section of olivine gabbro in the lower part of the section from 520 to 1508 mbsf also shows a relatively continuous upward evolution from primitive to less primitive compositions but with small breaks at the boundaries of the lithologic units. Again, small variations in composition within this sequence suggest intrusion of many magma pulses (Natland and Dick, Synthesis Chapter, this volume), but this interpretation is difficult to reconcile with the relatively consistent upward fractionation trend. We suggest that the section was formed from three major magmatic pulses (Series 3a, 3b, and 3c of Natland and Dick, Synthesis Chapter, this volume) which underwent fractionation in place. The small-scale compositional variations may reflect pulses of more mafic melt into these bodies or perhaps redistribution of interstitial liquids within the magma chamber.

As pointed out above, the most mafic rocks in Hole $735 \mathrm{~B}$ occur at the top of the section and the most differentiated rocks at the base. The relative ages of the different bodies is unknown, but Natland and Dick (Synthesis Chapter, this volume) suggest that the crustal section was formed from the top down by underplating. In this model melts rising from the mantle move upward until they encounter a permeability barrier, at which point they coalesce to form a magma chamber. The primitive olivine gabbros and troctolites at the top of the section represent small, solidified magma chambers from which melts may have erupted to the seafloor to form the basaltic carapace. The less differentiated gabbros lower in the section would have formed after the high-level plutons by injection of ferrobasaltic melts into the lower crust. Natland and Dick (Synthesis Chapter, this volume) suggest that the ferrobasaltic melts were produced by fractionation of the more mafic magmas that formed the small plutons at the top of the section. This is a reasonable model for construction of the cored section in Hole 735B, but more information is needed on the relative ages of the plutons and on the nature of the unsampled section beneath the hole before it can be adequately tested.

The compositions of the melts from which the Hole 735B gabbros crystallized can be estimated using the method of Roeder and Emslie (1970). Calculated melt compositions for the olivine gabbros and troctolites are all quite highly differentiated with Mg\#s generally between 35 and 60 . The olivine gabbros from the lower $987 \mathrm{~m}$ of Hole 735B crys-
F28. Downhole variation of $\mathrm{Zr}$, p. 55 .

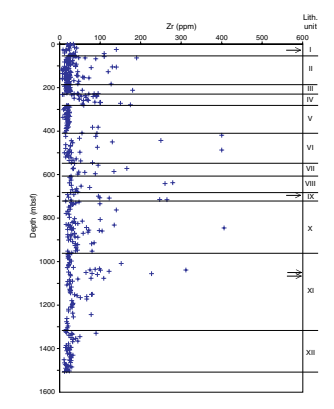

F29. Downhole variation of $\mathrm{Sr}$, p. 56.

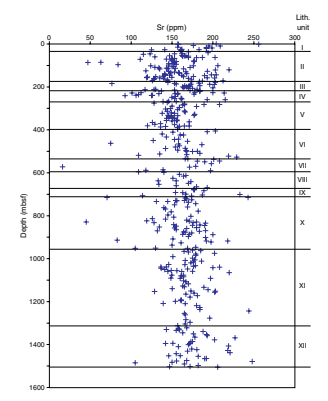

F30. Downhole variation of Sm, p. 57.

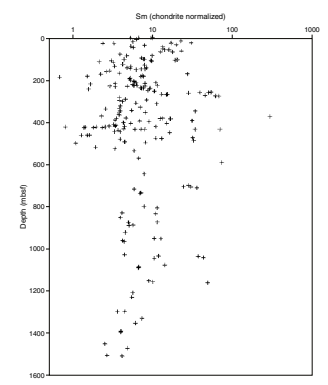

F31. Downhole variation of $\mathrm{La} / \mathrm{Yb}$, p. 58 .

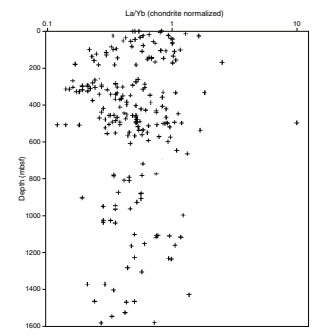


tallized from ferrobasalt liquids with Mg\#s generally between 35 and 45. Even the most primitive olivine gabbros and troctolites in the upper part of the section crystallized from relatively evolved abyssal tholeiites with Mg\#s between 50 and 60. Such ferrobasalts are virtually unknown from the Southwest Indian Ridge, suggesting that such liquids are trapped and crystallized in the lower crust before they can be erupted.

The bulk composition of the Hole 735B rocks is much too evolved to mass balance any reasonable crustal section back to a primitive melt composition (Dick et al., 2000). Thus, the parental magmas for the Hole 735B gabbros were considerably more evolved than any primary magma from the mantle suggesting an earlier stage of fractionation (Dick et al., 2000; Coogan et al., in press), which presumably would have produced primitive cumulates. If such cumulates exist they must lie either beneath the section sampled in Hole 735B or perhaps closer to the center of the transform-bounded ridge segment in which Atlantis Bank was formed. An alternative suggestion is that the relatively evolved melts were formed by reaction within the upper mantle and that the term "missing cumulates" is misleading (Coogan et al., in press).

One of the more surprising results of Legs 118 and 176 is the abundance of Fe-Ti oxide and oxide-bearing gabbros and gabbronorites in Hole 735B. These occur in layers and bands, a few millimeters to several meters thick, which appear to have intruded the dominant gabbro, olivine gabbro, and troctolite. Most, but not all of the oxide gabbros, are associated with zones of crystal-plastic deformation and, in many cases, the oxide minerals themselves are sheared and deformed. The origin of the melts from which the oxide gabbros and gabbronorites crystallized is unclear, but presumably they formed by extreme differentiation of the ferrobasaltic magmas. These are clearly highly evolved rocks as indicated by their modal and chemical compositions and their common association with trondhjemetic veins. However, the oxide gabbros are far too abundant to be mass balanced with the crustal section to any reasonable parental liquid. Thus, the Fe-Ti-rich melts must have formed beneath or adjacent to Hole 735B and have migrated into the section. It seems unlikely that such melts would move laterally along the ridge crest for any significant distance so they probably formed in the upper mantle or at the base of the crust beneath the drilled section. The Fe-Ti oxide melts would have been buoyant within a crystalline matrix (Natland and Dick, Synthesis Chapter, this volume) and would have risen to be concentrated in the upper parts of the crust. The extreme differentiation necessary to produce such melts must have formed an abundance of mafic cumulates beneath the ridge crest. Unlike the ferrogabbroic magmas mentioned above, the oxiderich magmas could not have been produced by melt-rock reaction in the upper mantle. The mafic cumulates produced during formation of the oxide-rich melts may not lie directly beneath the drill hole because the section was emplaced along a detachment fault, which separated it from the underlying mantle. A major question to be resolved by future drilling is whether the abundance of Fe-Ti oxide gabbros is unique to this portion of the Southwest Indian Ridge or whether such rocks are widely present in the lower ocean crust.
F32. Chondrite-normalized REE plots of representative samples, p. 59.

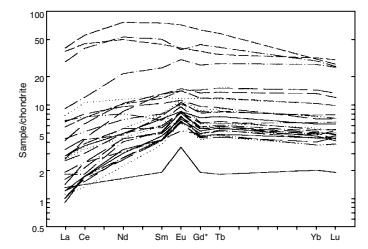

F33. Plot of La/Yb vs. Yb, p. 60.

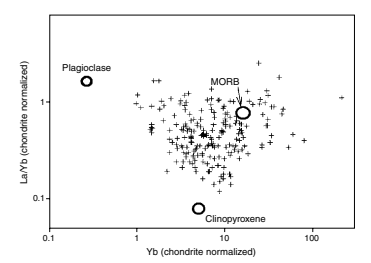


J. HeRTOGEN ET AL.

Lithology, Mineralogy, AND Geochemistry of The LoWer OCEAN Crust

\section{ACKNOWLEDGMENTS}

This research used samples provided by the Ocean Drilling Program (ODP). ODP is sponsored by the U.S. National Science Foundation (NSF) and participating countries under management of Joint Oceanographic Institutions (JOI), Inc. Funding for this research was provided by F.W.O. Vlaanderen (Belgium), the GeoForschungsZentrum (Germany), and the Natural Sciences and Engineering Research Council of Canada. 


\section{REFERENCES}

Bach, W., Erzinger, J., Alt, J.C., and Teagle, D.A.H., 1996. Chemistry of the lower sheeted dike complex, Hole 504B (Leg 148): influence of magmatic differentiation and hydrothermal alteration. In Alt, J.C., Kinoshita, H., Stokking, L.B., and Michael, P.J. (Eds.), Proc. ODP, Sci. Results, 148: College Station, TX (Ocean Drilling Program), 39-55.

Bankston, D.C., Humphris, S.E., and Thompson, G., 1979. Major and minor oxide and trace element determination in silicate rocks by direct current plasma optical emission echelle spectrometry. Anal. Chem., 51:1218-1225.

Barling, J., Hertogen, J., and Weis, D., 1997. Whole-rock geochemistry and Sr-, Nd-, and $\mathrm{Pb}$-isotopic characteristics of undeformed, deformed, and recrystallized gabbros from Sites 921, 922, and 923 in the MARK area. In Karson, J.A., Cannat, M., Miller, D.J., and Elthon, D. (Eds.), Proc. ODP, Sci. Results, 153: College Station, TX (Ocean Drilling Program), 351-362.

Bloomer, S.H., Meyer, P.S., Dick, H.J.B., Ozawa, K., and Natland, J.H., 1991. Textural and mineralogic variations in gabbroic rocks from Hole 735B. In Von Herzen, R.P., Robinson, P.T., et al., Proc. ODP, Sci. Results, 118: College Station, TX (Ocean Drilling Program), 21-39.

Boström, K., and Bach, W., 1995. Trace element determinations by X-ray fluorescence analysis: advantages, limitations, and alternatives. In Batiza, R., Storms, M.A., and Allan, J.F. (Eds.), Proc. ODP, Sci. Results, 142: College Station, TX (Ocean Drilling Program), 61-68.

Coogan, L.A, MacLeod, C.J., Dick, H.J.B., Edwards, S.J., Kvassnes, A., Natland, J.H., Robinson, P.T., Thompson, G., and O'Hara, M.J., in press. Whole-rock geochemistry of gabbros from the Southwest Indian Ridge: constraints on geochemical fractionations between the upper and lower oceanic crust and magma chamber processes at (very) slow-spreading ridges. Chem. Geo.

Detrick, R., Collins, J., Stephen, R., and Swift, S., 1994. In situ evidence for the nature of the seismic layer 2/3 boundary in oceanic crust. Nature, 370:288-290.

Dick, H.J.B., Meyer, P.S., Bloomer, S., Kirby, S., Stakes, D., and Mawer, C., 1991 a. Lithostratigraphic evolution of an in-situ section of oceanic Layer 3. In Von Herzen, R.P., Robinson, P.T., et al., Proc. ODP, Sci. Results, 118: College Station, TX (Ocean Drilling Program), 439-538.

Dick, H.J.B., Natland, J.H., Alt, J.C., Bach, W., Bideau, D., Gee, J.S., Haggas, S., Hertogen, J.G.H., Hirth, G., Holm, P.M., Ildefonse, B., Iturrino, G.J., John, B.E., Kelley, D.S., Kikawa, E., Kingdon, A., LeRoux, P.J., Maeda, J., Meyer, P.S., Miller, D.J., Naslund, H.R., Niu, Y., Robinson, P.T., Snow, J., Stephen, R.A., Trimby, P.W., Worm, H.-U., and Yoshinobu, A., 2000. A long in situ section of the lower ocean crust: results of ODP Leg 176 drilling at the Southwest Indian Ridge. Earth Planet. Sci. Lett., 179:31-51.

Dick, H.J.B., Natland, J.H., Miller, D.J., et al., 1999. Proc. ODP, Init. Repts., 176 [CDROM] . Available from: Ocean Drilling Program, Texas A\&M University, College Station, TX 77845-9547, U.S.A.

Dick, H.J.B., Robinson, P.T., and Meyer, P.S., 1992. The plutonic foundation of a slowspreading ridge. In Duncan, R., Rea, D., Kidd, R., von Rad, U., and Weissel, J. (Eds.), Synthesis of Results from Scientific Drilling in the Indian Ocean. Geophys. Monogr., Am. Geophys. Union, 70:1-50.

Dick, H.J.B., Schouten, H., Meyer, P.S., Gallo, D.G., Berg, H., Tyce, R., Patriat, P., Johnson, K., Snow, J., and Fisher, A., 1991b. Bathymetric map of the Atlantis II Fracture Zone, Southwest Indian Ridge. In Von Herzen, R.P., Robinson, P.T., et al., Proc. ODP, Sci. Results, 118: College Station, TX (Ocean Drilling Program), back pocket map. 
1991c. Tectonic evolution of the Atlantis II Fracture Zone. In Von Herzen, R.P., Robinson, P.T., et al., Proc. ODP, Sci. Results, 118: College Station, TX (Ocean Drilling Program), 359-398.

Emmermann, R., and Lauterjung, J., 1990. Double X-ray analysis of cuttings and rock flour: a powerful tool for rapid and reliable determination of borehole lithostratigraphy. Sci. Drill., 1:269-282.

Erzinger, J., and Puchelt, H., 1982. Die Bestimmung umweltrelvante Spurenelemente in geologischem Material. Erzmetall, 35:173-179.

Govindaraju, K., 1994. 1994 compilation of working values and sample description for 383 geostandards. Geostand. Newsl., 18 (spec. iss.).

Hébert, R., Constantin, M., and Robinson, P.T., 1991. Primary mineralogy of Leg 118 gabbroic rocks and their place in the spectrum of oceanic mafic igneous rocks. In Von Herzen, R.P., Robinson, P.T., et al., Proc. ODP, Sci. Results, 118: College Station, TX (Ocean Drilling Program), 3-20.

Hertogen, J., and Gijbels, R., 1981. Instrumental neutron activation analysis of silicate rocks with low-energy photon detector. Geochim. Cosmochim. Acta, 56:61-82.

Iturrino, G.J., Christensen, N.I., Kirby, S., and Salisbury, M.H., 1991. Seismic velocities and elastic properties of oceanic gabbroic rocks from Hole 735B. In Von Herzen, R.P., Robinson, P.T., et al., Proc. ODP, Sci. Results, 118: College Station, TX (Ocean Drilling Program), 227-244.

MacLeod, C.J., Allerton, S., Dick, H.J.B., Robinson, P.T., Campbell, N., Derrick. J., Graham, C., Tulloch, G., Wallis, D., Coogan, L.A., Edwards, S.J., Gillis, K.M., Hunter, A.G., Hutchinson, D., Kvassnes, A.J., Natland, J.H., Salisbury, M., Stakes, D.S., Thompson, G.M., and Tivey, M.A., 1998. Drilling the lower ocean crust: wireline rock drilling of Atlantis Bank, SW Indian Ridge. BRIDGE Newsl., 16:53-54.

Natland, J.H., Meyer, P.S., Dick, H.J.B., and Bloomer, S.H., 1991. Magmatic oxides and sulfides in gabbroic rocks from Hole 735B and the later development of the liquid line of descent. In Von Herzen, R.P., Robinson, P.T., et al., Proc. ODP, Sci. Results, 118: College Station, TX (Ocean Drilling Program), 75-111.

Ozawa, K., Meyer, P.S., and Bloomer, S.H., 1991. Mineralogy and textures of irontitanium oxide gabbros and associated olivine gabbros from Hole 735B. In Von Herzen, R.P., Robinson, P.T., et al., Proc. ODP, Sci. Results, 118: College Station, TX (Ocean Drilling Program), 41-73.

Pedersen, R.B., and Hertogen, J., 1990. Magmatic evolution of the Karmoy ophiolite complex, SW Norway: relationships between MORB-IT-boninitic-calc-alkaline and alkaline magmatism. Contrib. Mineral. Petrol., 104:277-293.

Robinson, P.T., Dick, H.J.B., Natland, J.H., and the ODP Leg 176 Shipboard Party, 2000. Lower oceanic crust formed at an ultra-slow-spreading ridge: Ocean Drilling Program Hole 735B, Southwest Indian Ridge. In Dilek, Y., Moores, E., Elthon, D., and Nicolas, A. (Eds.), Ophiolites and Oceanic Crust: New Insights from Field Studies and the Ocean Drilling Program, Spec. Pap.-Geol. Soc. Am., 349:75-86.

Robinson, P.T., Von Herzen, R., et al., 1989. Proc. ODP, Init. Repts., 118: College Station, TX (Ocean Drilling Program).

Roeder, P.L., and Emslie, R.F., 1970. Olivine-liquid equilibrium. Contrib. Mineral. Petrol., 29:275-289.

Shafer, H.N.S., 1996. The determination of iron(II) oxide in silicate and refractory materials. Part II. The Analyst, 91:755-762.

Shipboard Scientific Party, 1989. Introduction and explanatory notes. In Robinson, P.T., Von Herzen, R., et al., Proc. ODP, Init. Repts., 118: College Station, TX (Ocean Drilling Program), 3-24.

— 1999. Leg 176 summary. In Dick, H.J.B., Natland, J.H., Miller, D.J., et al., Proc. ODP, Init. Repts., 176: College Station, TX (Ocean Drilling Program), 1-70.

Sparks, J.W., and Zuleger, E., 1995. Data report: Chemical analyses of the Leg 140 reference sample. In Erzinger, J., Becker, K., Dick, H.J.B., Stokking, L.B. (Eds.), Proc. ODP, Sci. Results, 137/140: College Station, TX (Ocean Drilling Program), 353-355. 
J. HERTOGEN ET AL.

Lithology, Mineralogy, AND GEOCHEMistry OF THE LOWER OCEAN CRUST

Stakes, D., Mével, C., Cannat, M., and Chaput, T., 1991. Metamorphic stratigraphy of Hole 735B. In Von Herzen, R.P., Robinson, P.T., et al., Proc. ODP, Sci. Results, 118: College Station, TX (Ocean Drilling Program), 153-180.

Von Herzen, R.P., Robinson, P.T., et al., 1991. Proc. ODP, Sci. Results, 118: College Station, TX (Ocean Drilling Program).

Zuleger, E., Alt, J.C., and Erzinger, J., 1996. Data report: Trace-element geochemistry of the lower sheeted dike complex, Hole 504B, Leg 140. In Alt, J.C., Kinoshita, H., Stokking, L.B., and Michael, P.J. (Eds.), Proc. ODP, Sci. Results, 148: College Station, TX (Ocean Drilling Program), 455-466.

- 1995. Primary and secondary variations in major and trace element geochemistry of the lower sheeted dike complex: Hole 504B, Leg 140. In Erzinger, J., Becker, K., Dick, H.J.B., and Stokking, L.B. (Eds.), Proc. ODP, Sci. Results, 137/140: College Station, TX (Ocean Drilling Program), 65-80.

Zuleger, E., and Erzinger, J., 1988. Determination of the REE and Y in silicate materials with ICP-AES. Fresenius' Z. Anal. Chem., 332:140-143. 
J. HERTOGEN ET AL.

Lithology, Mineralogy, AND Geochemistry of The LoWer OCEAN Crust

Figure F1. Map showing the location of Hole 735B on the Southwest Indian Ridge.

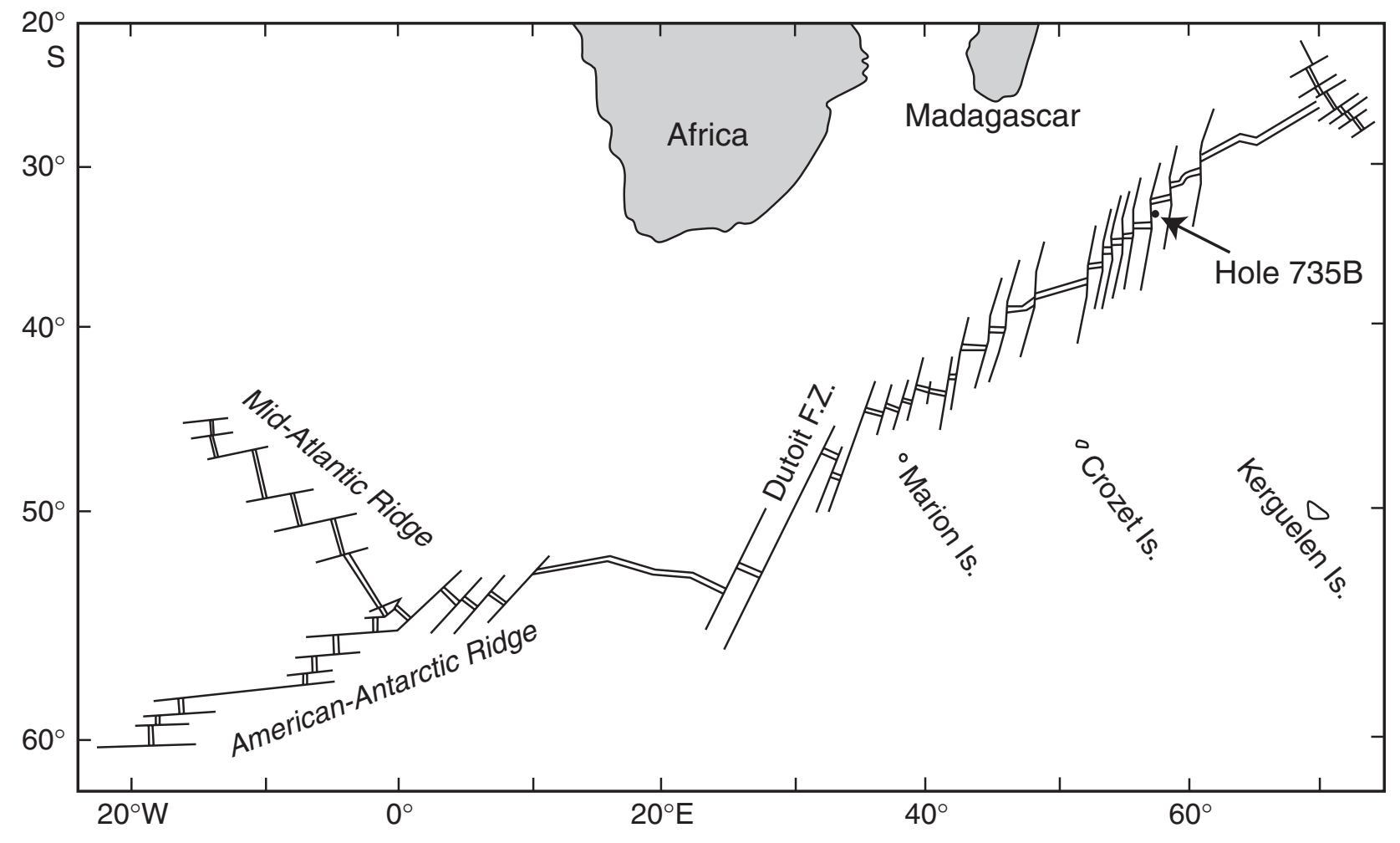




\section{J. HERTOGEN ET AL.}

Figure F2. Lithologic column for Hole 735B showing the 12 major lithologic units. A. Relative abundance of rock types averaged over 20-m intervals. B-D. Downhole distribution of pegmatitic gabbro, microgabbro, and igneous layering, respectively (after Dick, Natland, Miller, et al., 1999).

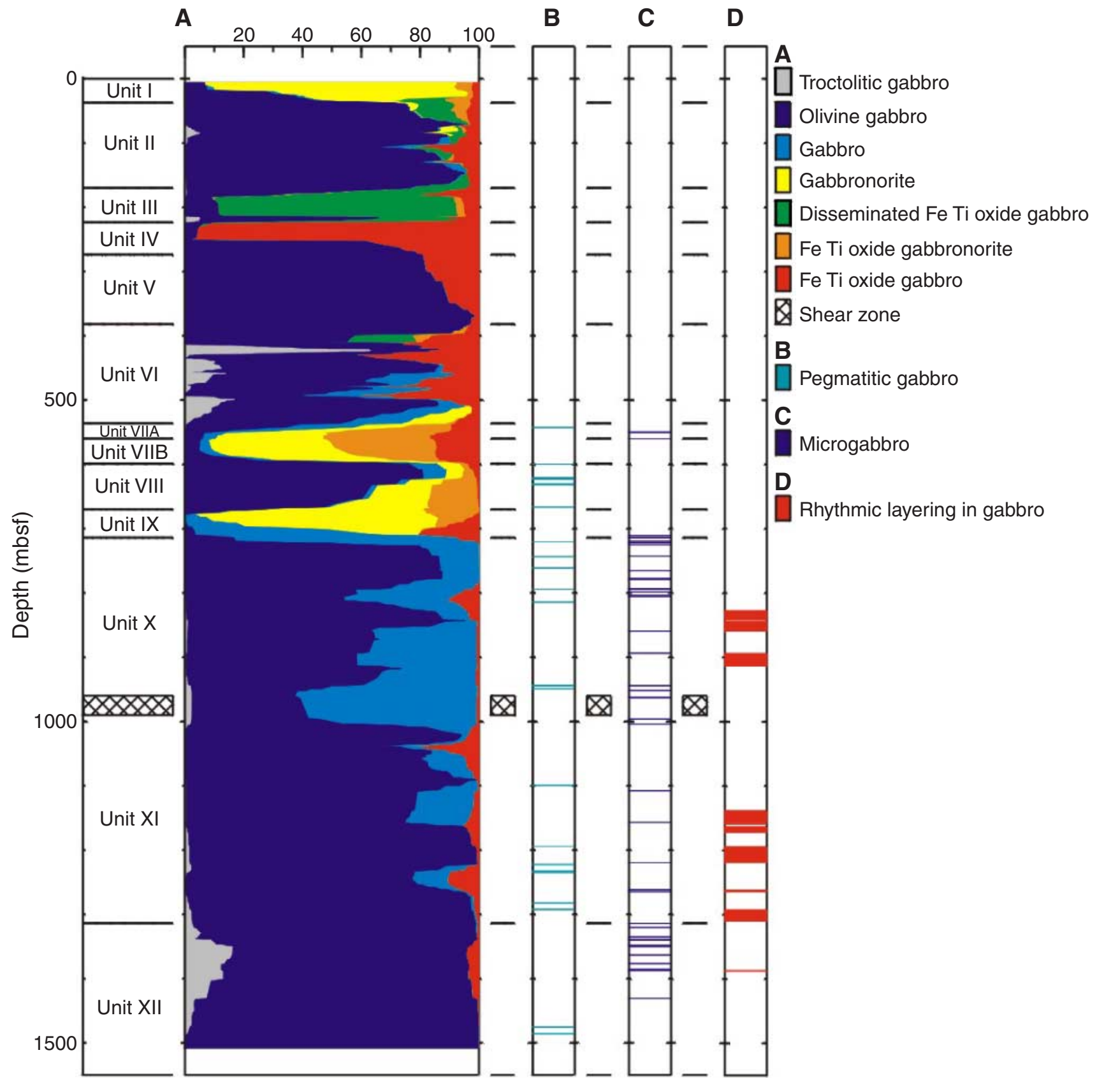


J. HeRTOGEN ET AL.

Lithology, Mineralogy, AND Geochemistry of The Lower OCEAn Crust

30

Figure F3. Downhole variation of olivine compositions (Fo) in Hole 735B. Roman numerals indicate the major lithologic units, and the bars indicate the range of composition of olivine within a given sample.

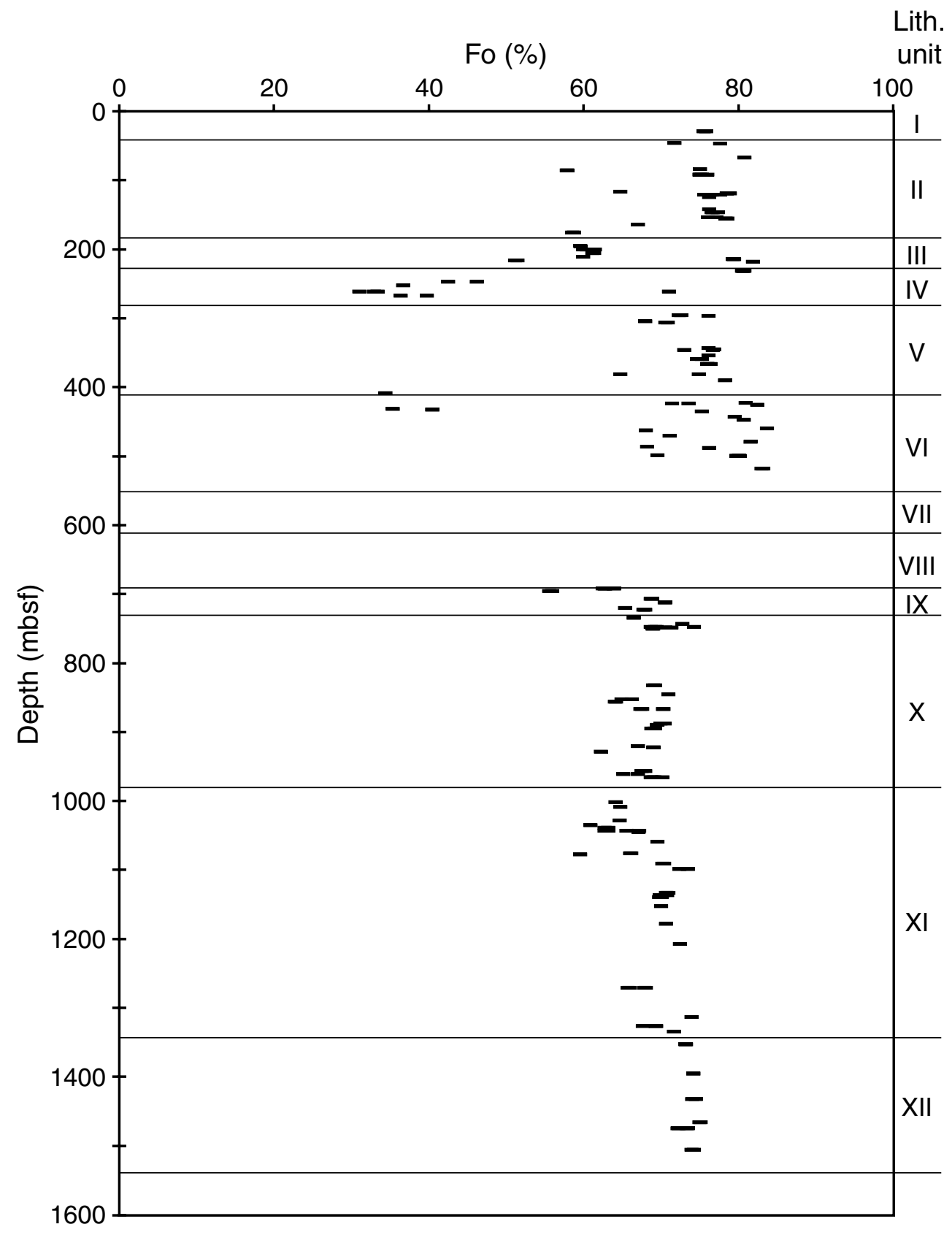


J. Hertogen ET AL.

Lithology, Mineralogy, AND Geochemistry of The LoWer OCEAN Crust

Figure F4. Downhole variation of orthopyroxene compositions (Mg\#) in Hole 735B. Roman numerals indicate the major lithologic units, and the bars indicate the range of composition of orthopyroxene within a given sample.

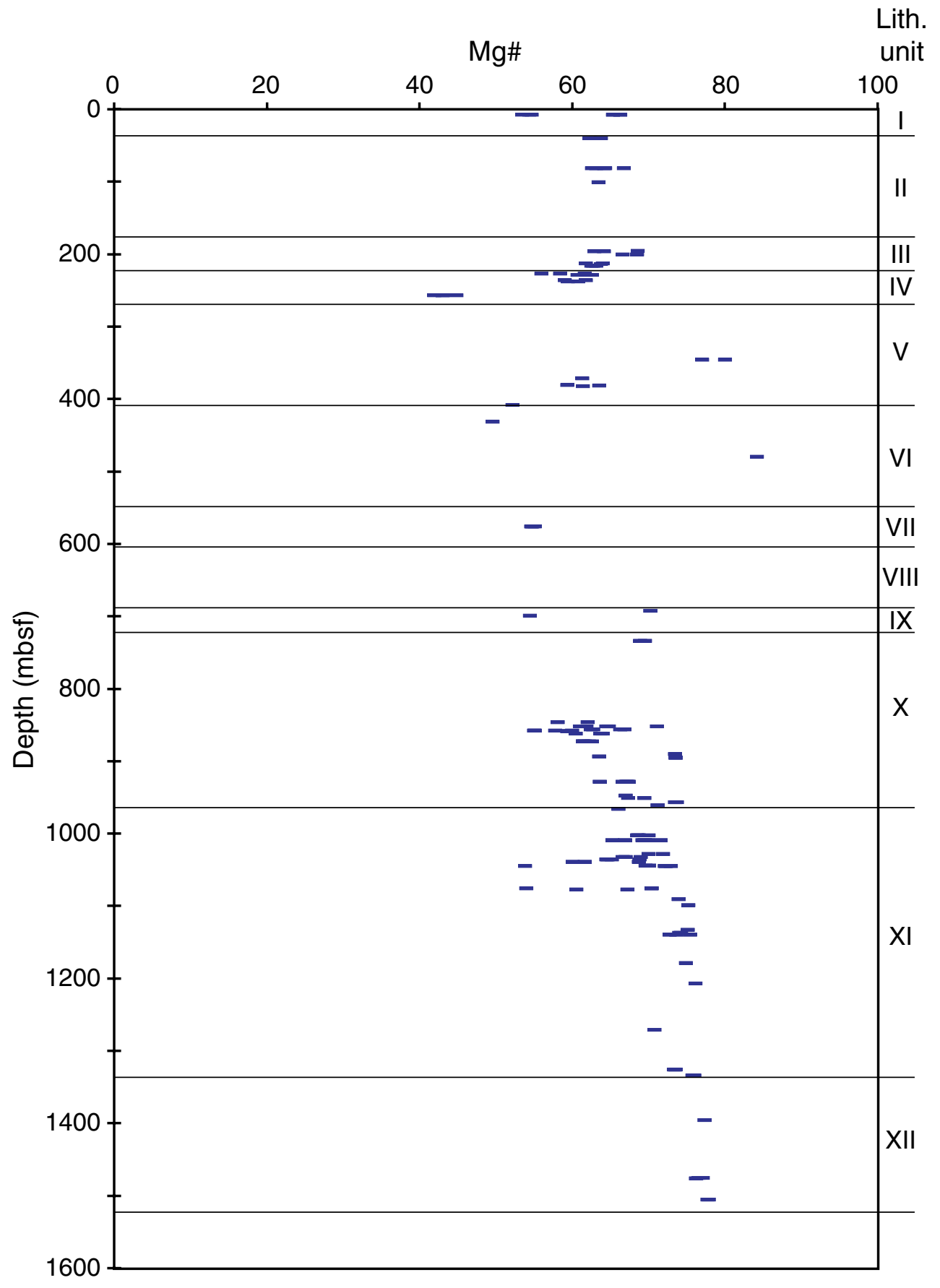


J. Hertogen ET AL.

Lithology, Mineralogy, ANd Geochemistry of The Lower OCEAN Crust

Figure F5. Downhole variation of clinopyroxene compositions (Mg\#) in Hole 735B. Roman numerals indicate the major lithologic units, and the bars indicate the range of composition of clinopyroxene within a given sample.

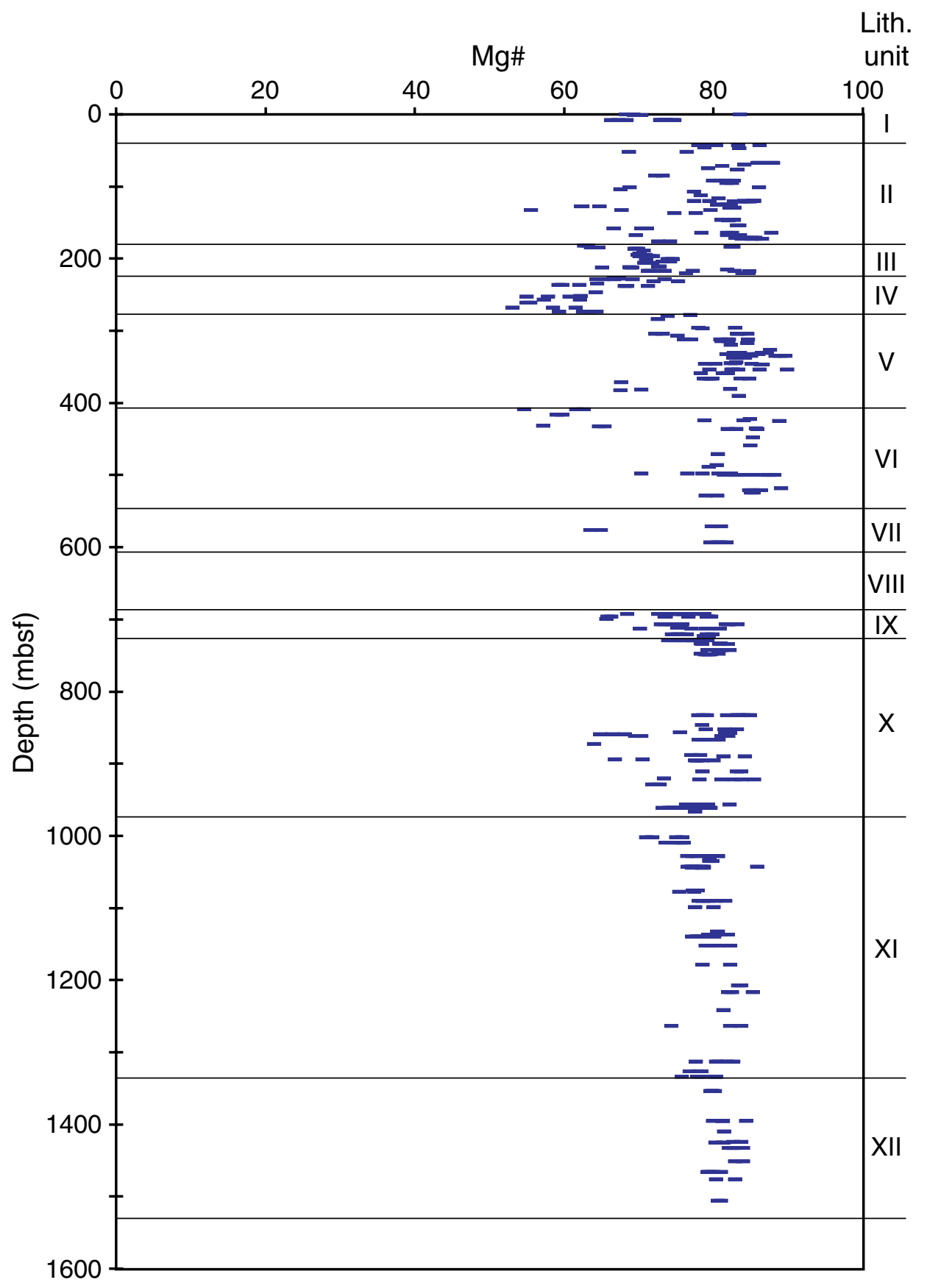




\section{J. HeRTOGEN ET AL.}

Figure F6. Downhole variation of plagioclase compositions (An content) in Hole 735B. Roman numerals indicate the major lithologic units, and the bars indicate the range of composition of plagioclase within a given sample.

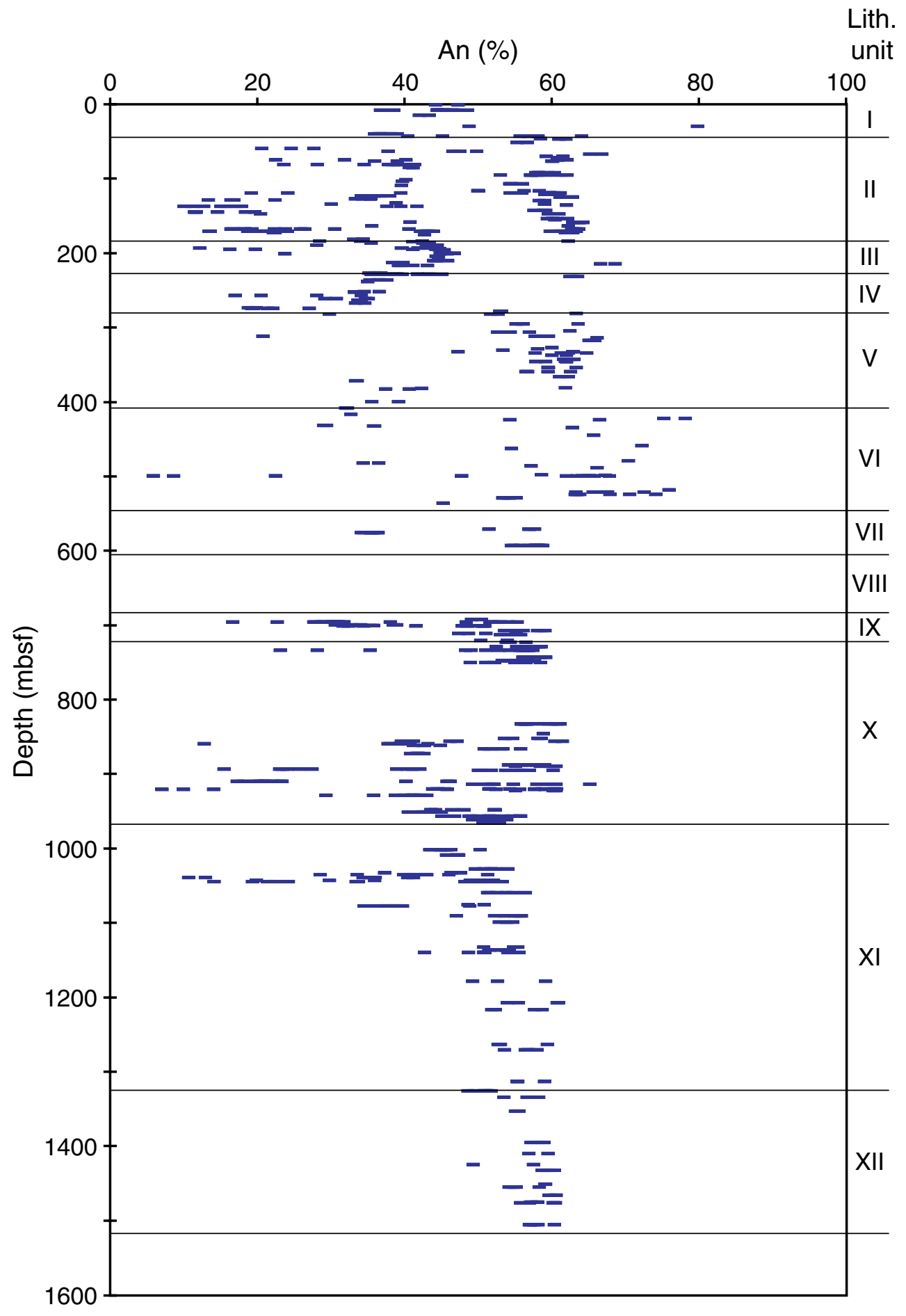


J. Hertogen ET AL.

Lithology, Mineralogy, AND Geochemistry of The LoWer OCEAN Crust

Figure F7. Downhole variation of $\mathrm{SiO}_{2}$ in Hole 735B. Roman numerals indicate the major lithologic units. $+=$ analyzed value.

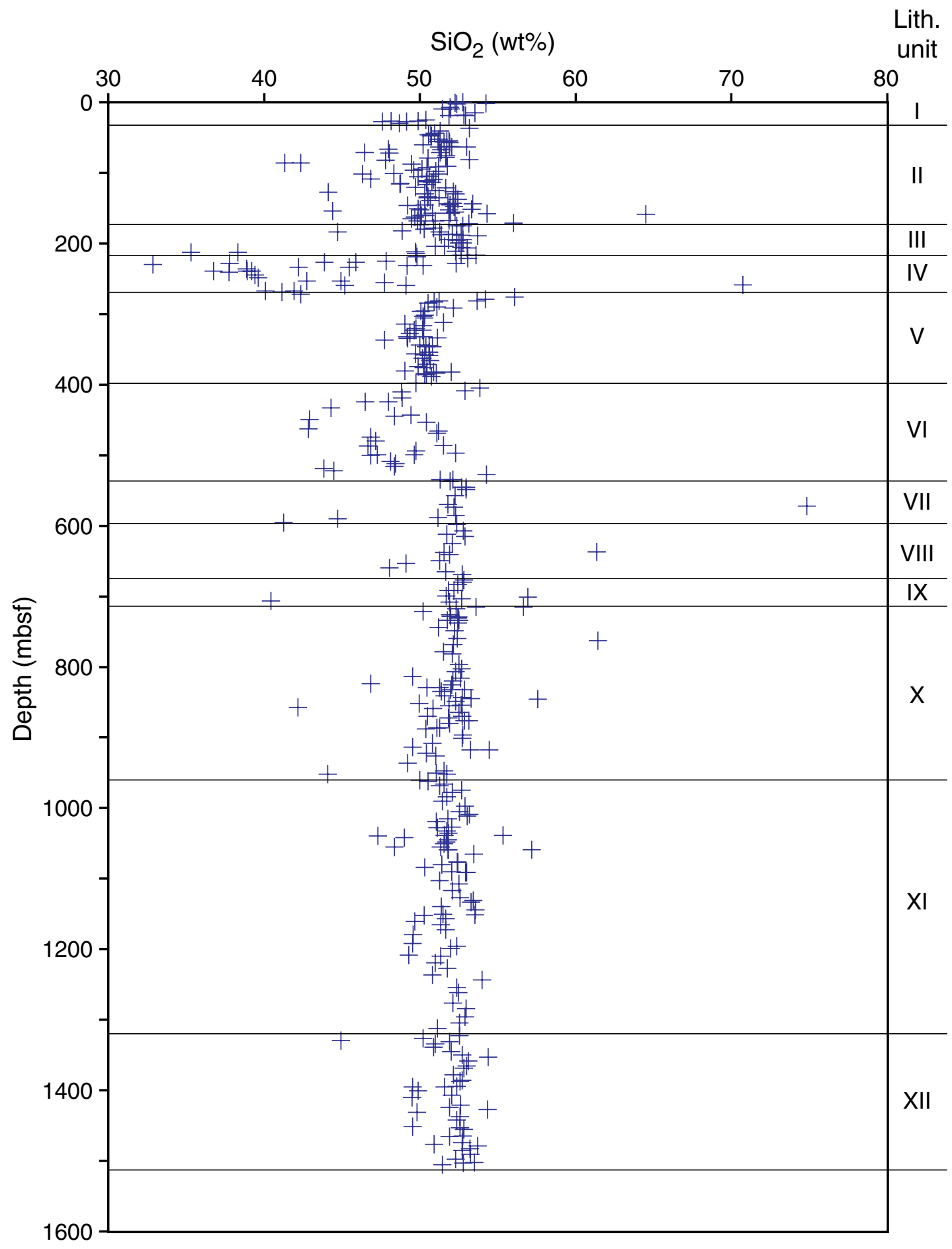




\section{J. HeRTogen ET AL.}

Lithology, Mineralogy, AND Geochemistry of The LoWer OCEAN Crust

Figure F8. Downhole variation of $\mathrm{Al}_{2} \mathrm{O}_{3}$ in Hole 735B. Roman numerals indicate the major lithologic units. $+=$ analyzed value.

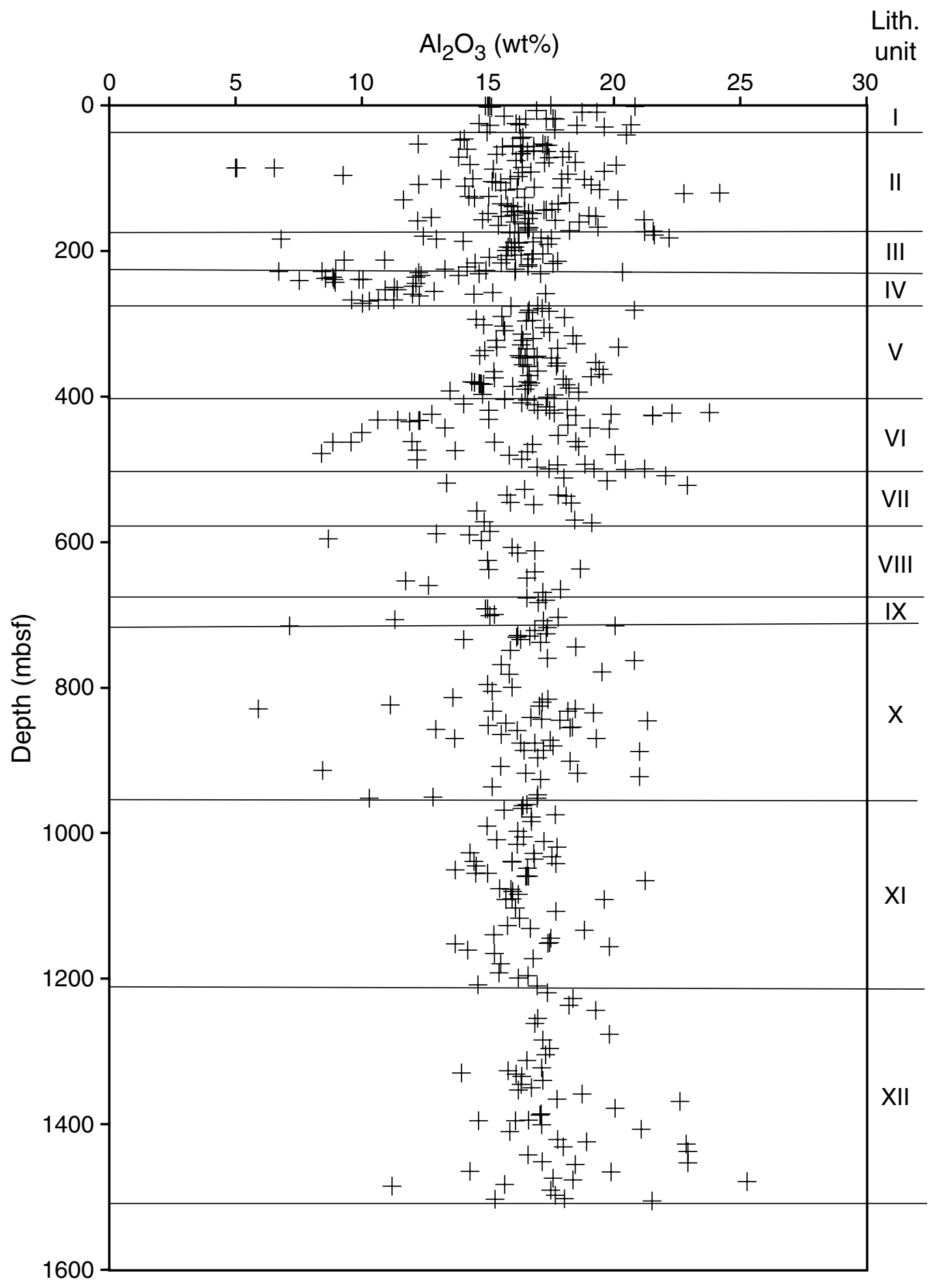


J. HerTOGEN ET AL.

Lithology, Mineralogy, AND Geochemistry of The LoWer OCEAN Crust

Figure F9. Downhole variation of $\mathrm{TiO}_{2}$ in Hole 735B. Roman numerals indicate the major lithologic units. $+=$ analyzed value.

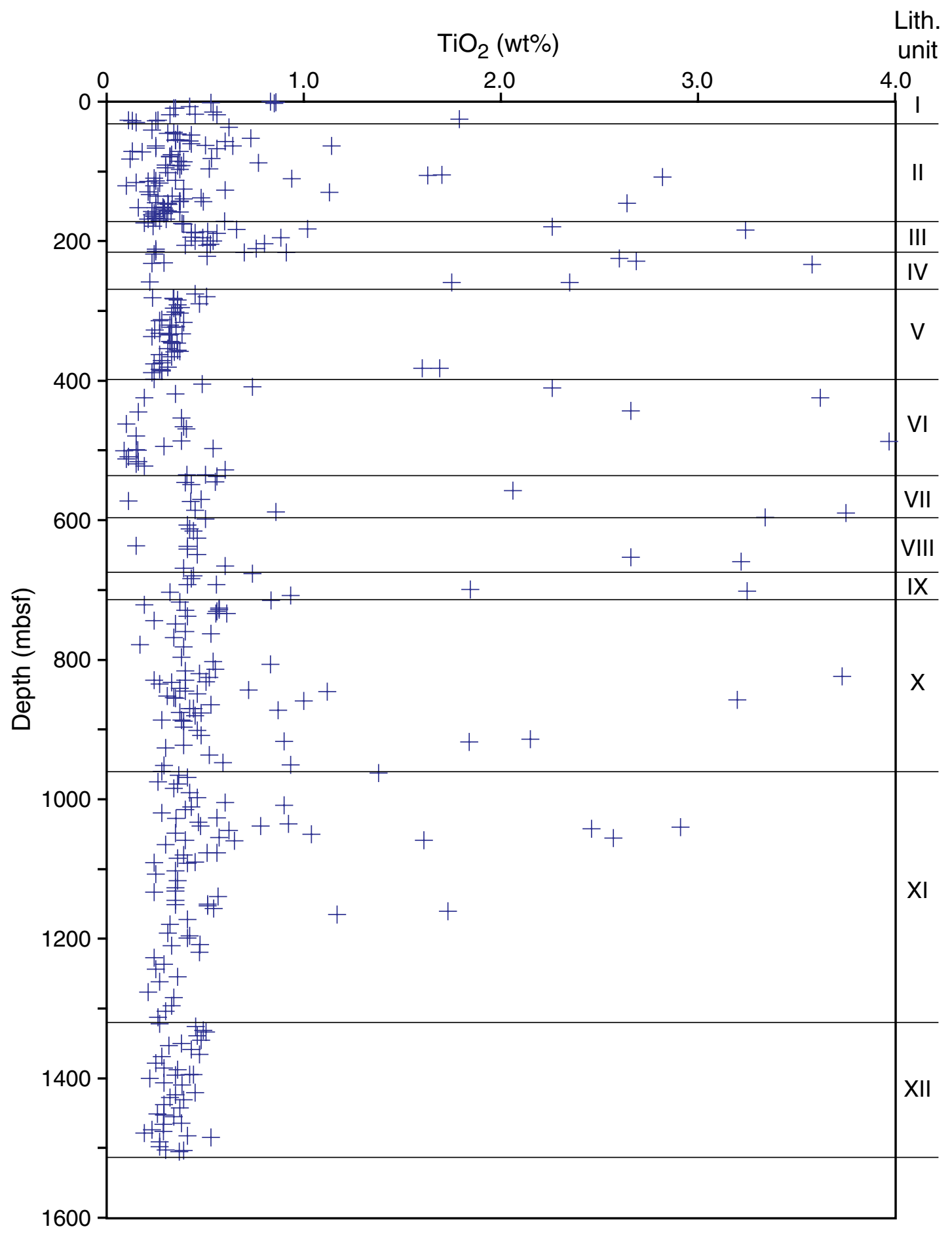




\section{J. HeRTogen ET AL.}

Lithology, Mineralogy, AND Geochemistry of the Lower OCEAn Crust

Figure F10. Downhole variation of $\mathrm{Fe}_{2} \mathrm{O}_{3 \text { total }}$ in Hole 735B. Roman numerals indicate the major lithologic units. $+=$ analyzed value.

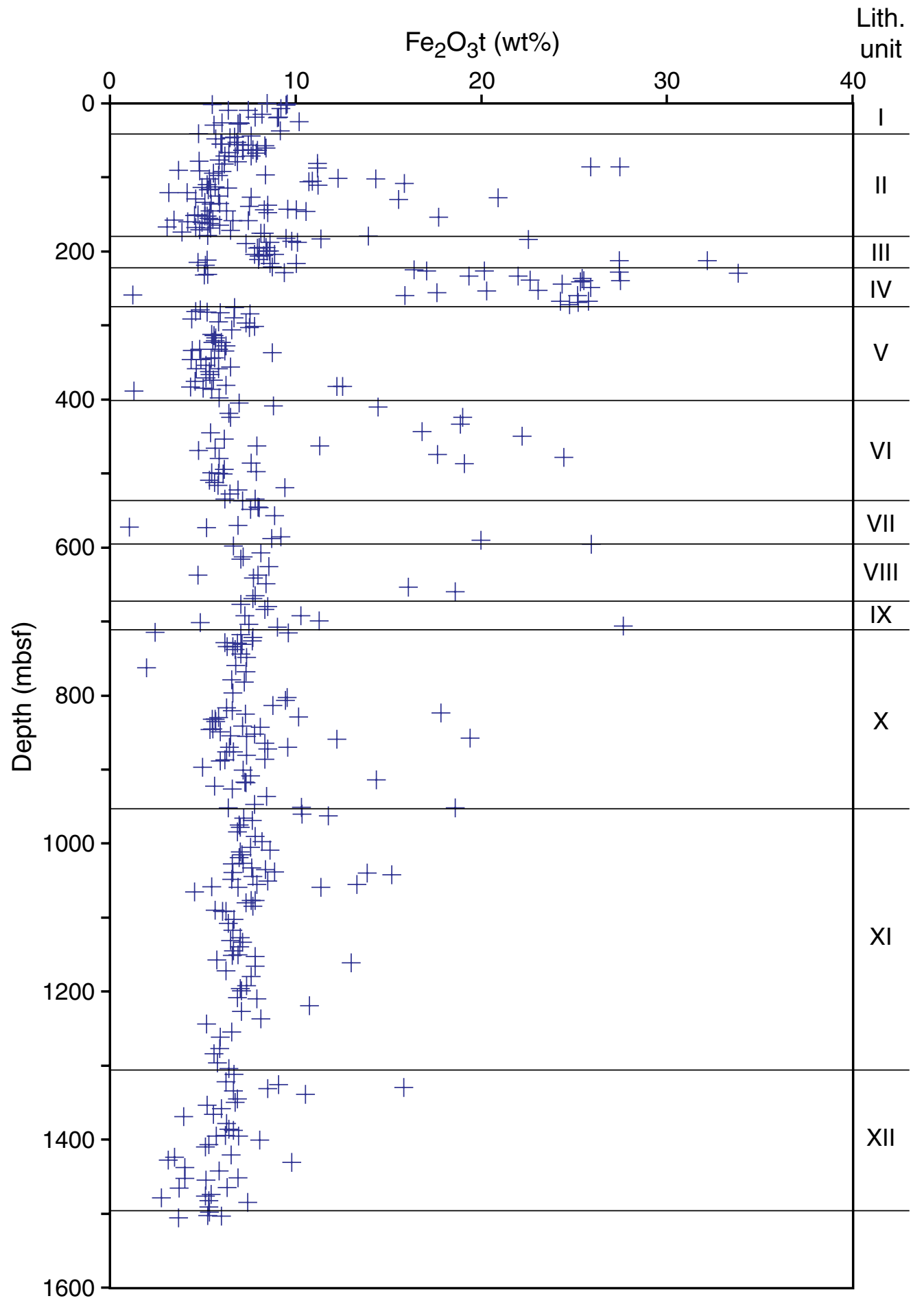


J. Hertogen ET AL.

Lithology, Mineralogy, AND Geochemistry of The LoWer OCEAN Crust

Figure F11. Downhole variation of MnO in Hole 735B. Roman numerals indicate the major lithologic units. $+=$ analyzed value. Arrow indicates a value $>2.0 \mathrm{wt} \%$.

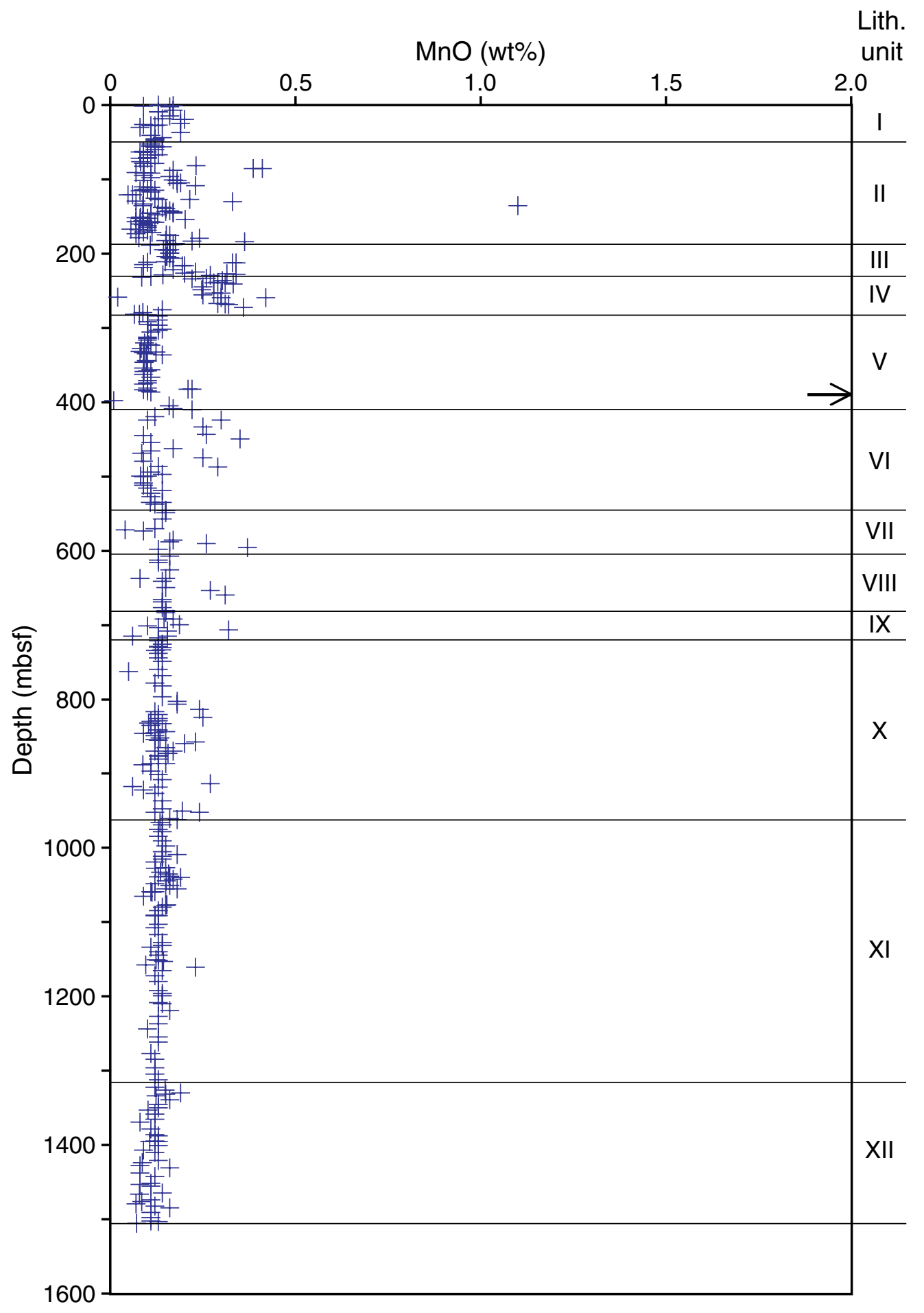




\section{J. HeRTOGEN ET AL.}

Lithology, Mineralogy, AND Geochemistry of The Lower OCEAN Crust

Figure F12. Downhole variation of $\mathrm{MgO}$ in Hole 735B. Roman numerals indicate the major lithologic units. $+=$ analyzed value. Arrow indicates a value $>25 \mathrm{wt} \%$.

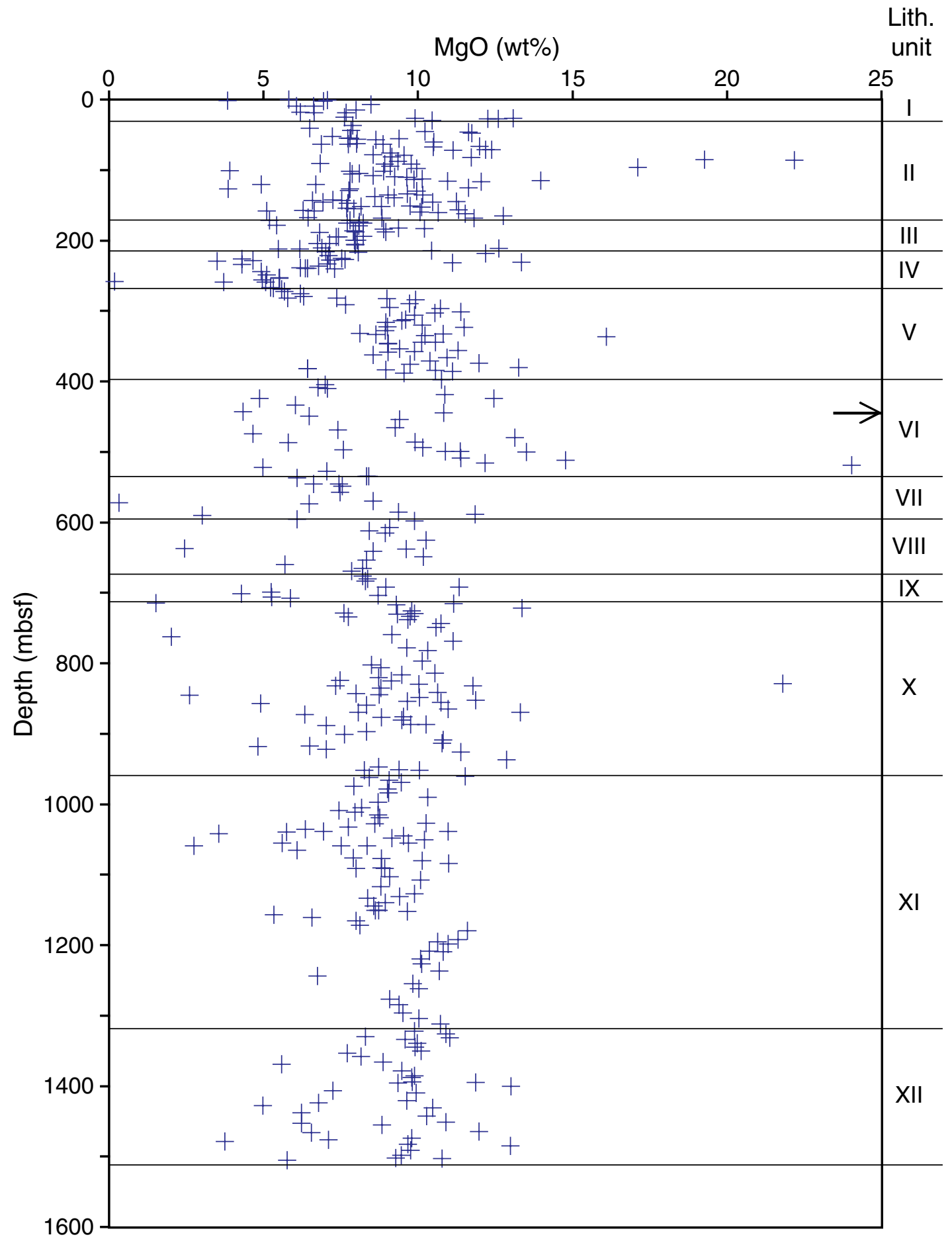


J. HerTOGEN ET AL.

Lithology, Mineralogy, AND Geochemistry of The LoWer OCEAN Crust

Figure F13. Downhole variation of Mg\# in 735B. Roman numerals indicate the major lithologic units. $+=$ analyzed value.

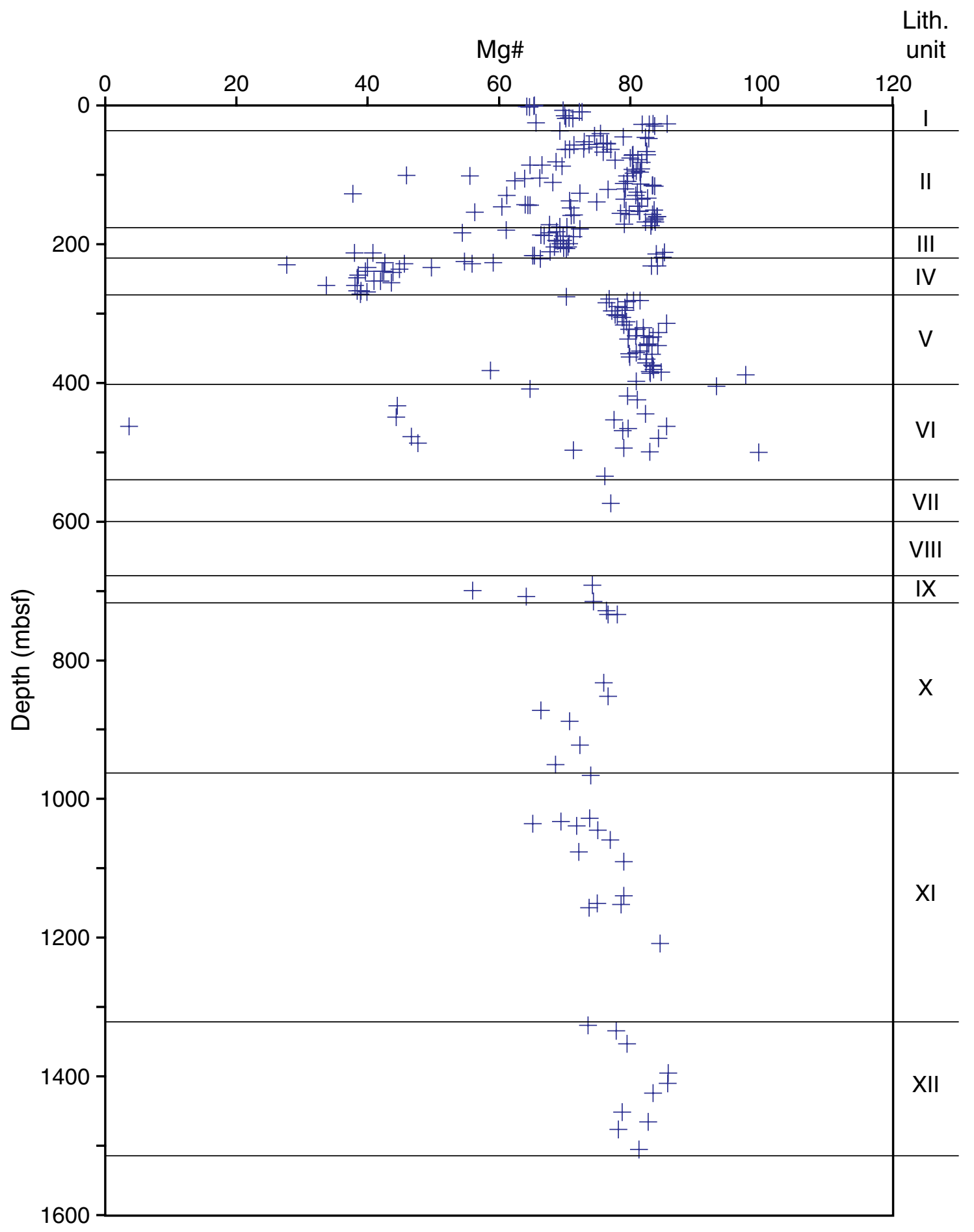


J. Hertogen ET AL.

Lithology, Mineralogy, AND Geochemistry of The LoWer OCEAN Crust

Figure F14. Downhole variation of $\mathrm{Mg} \# 80$ in Hole 735B. Calculated by taking $\mathrm{FeO}$ as $80 \%$ of total iron. Roman numerals indicate the major lithologic units. $+=$ analyzed value.

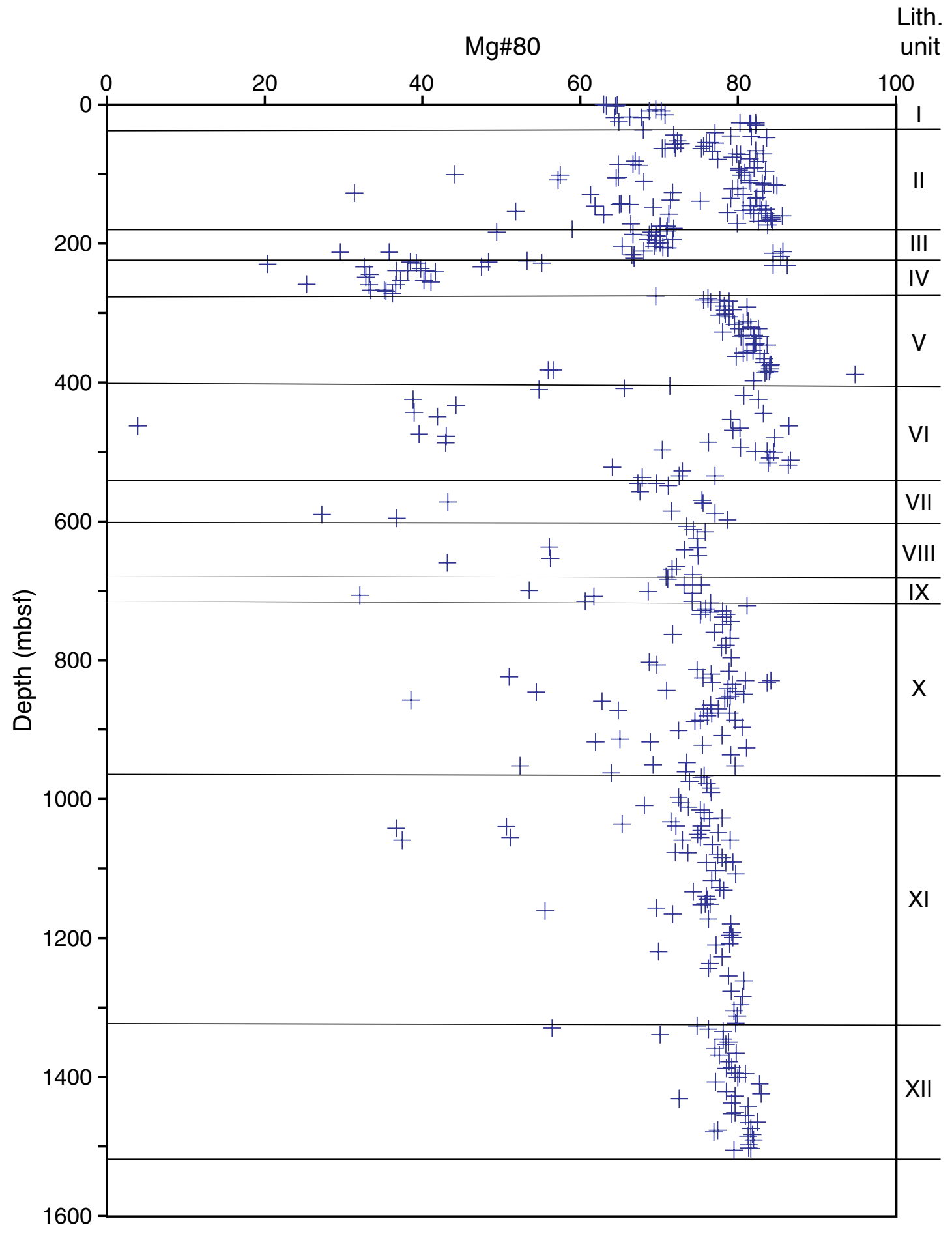


J. HerTOGEN ET AL.

Lithology, Mineralogy, AND Geochemistry of The LoWer OCEAN Crust

Figure F15. Downhole variation of $\mathrm{CaO}$ in Hole 735B. Roman numerals indicate the major lithologic units. $+=$ analyzed value.

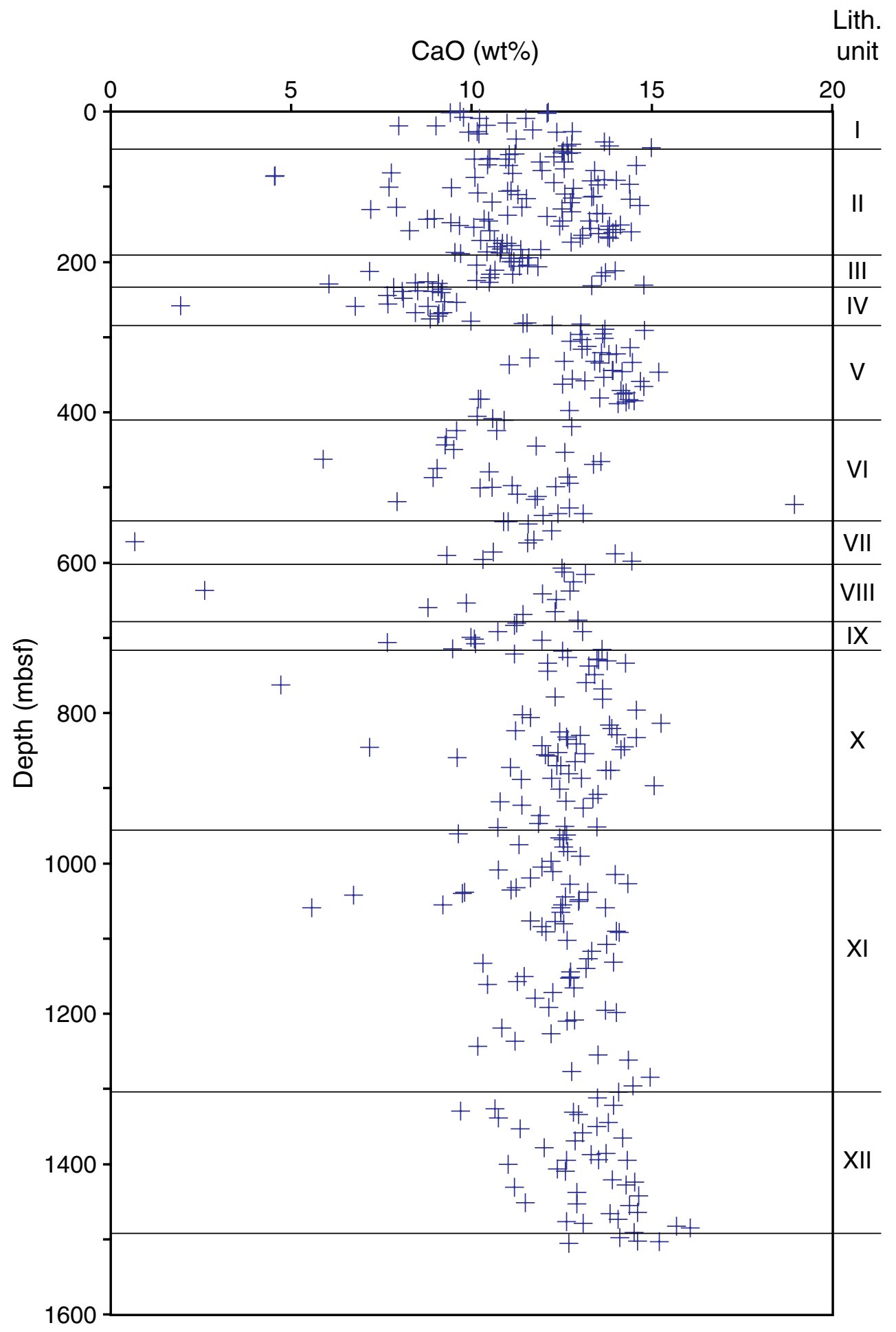




\section{J. HeRTogen ET AL.}

Lithology, Mineralogy, AND Geochemistry of The LoWer OCEAN Crust

Figure F16. Downhole variation of $\mathrm{Na}_{2} \mathrm{O}$ in Hole 735B. Roman numerals indicate the major lithologic units. $+=$ analyzed value. Arrow indicates a value $>10 \mathrm{wt} \%$.

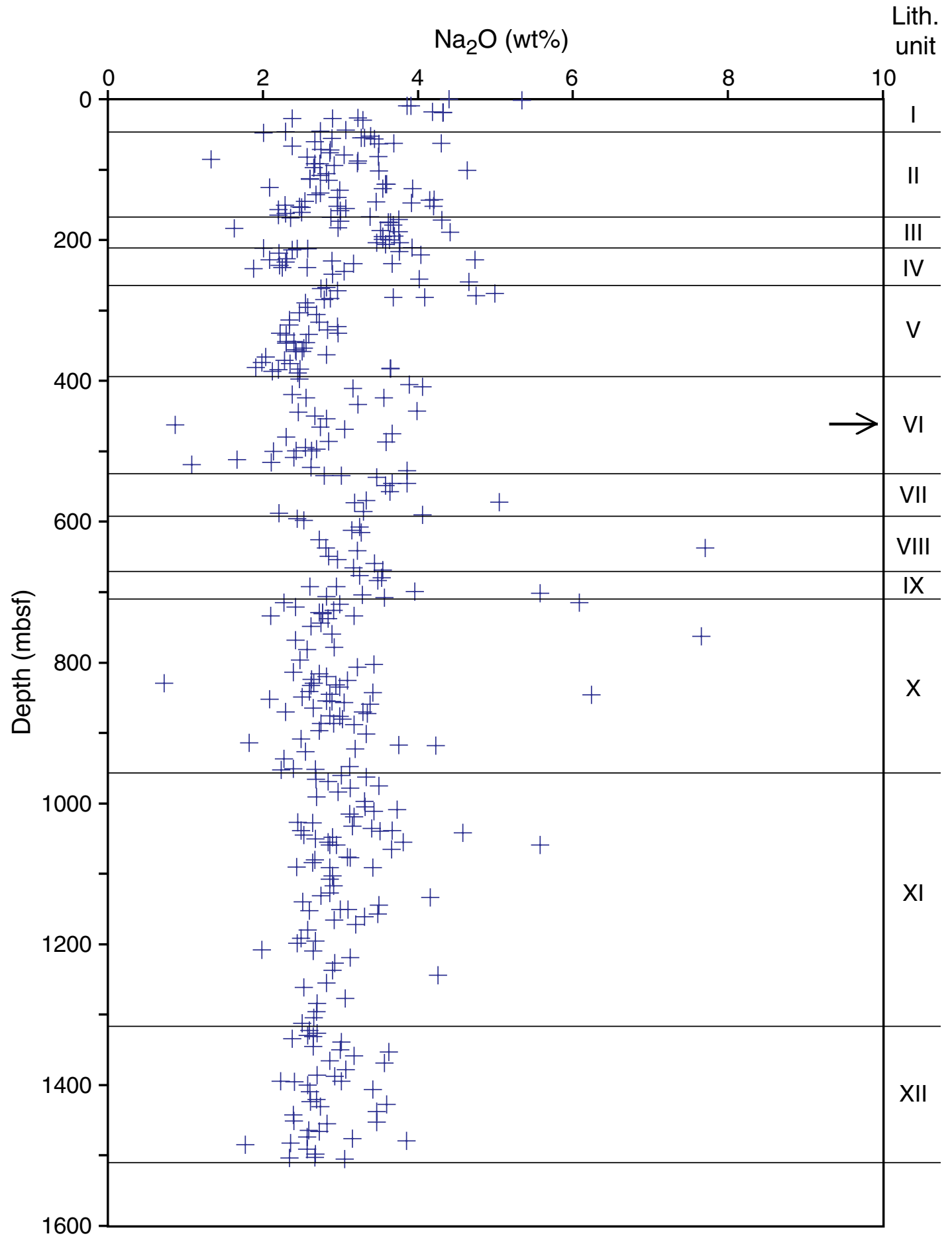


J. Hertogen ET AL.

Lithology, Mineralogy, AND Geochemistry of The LoWer OCEAN Crust

Figure F17. Downhole variation of $\mathrm{K}_{2} \mathrm{O}$ in Hole 735B. Roman numerals indicate the major lithologic units. $+=$ analyzed value. Arrow indicates a value $>2.0 \mathrm{wt} \%$.

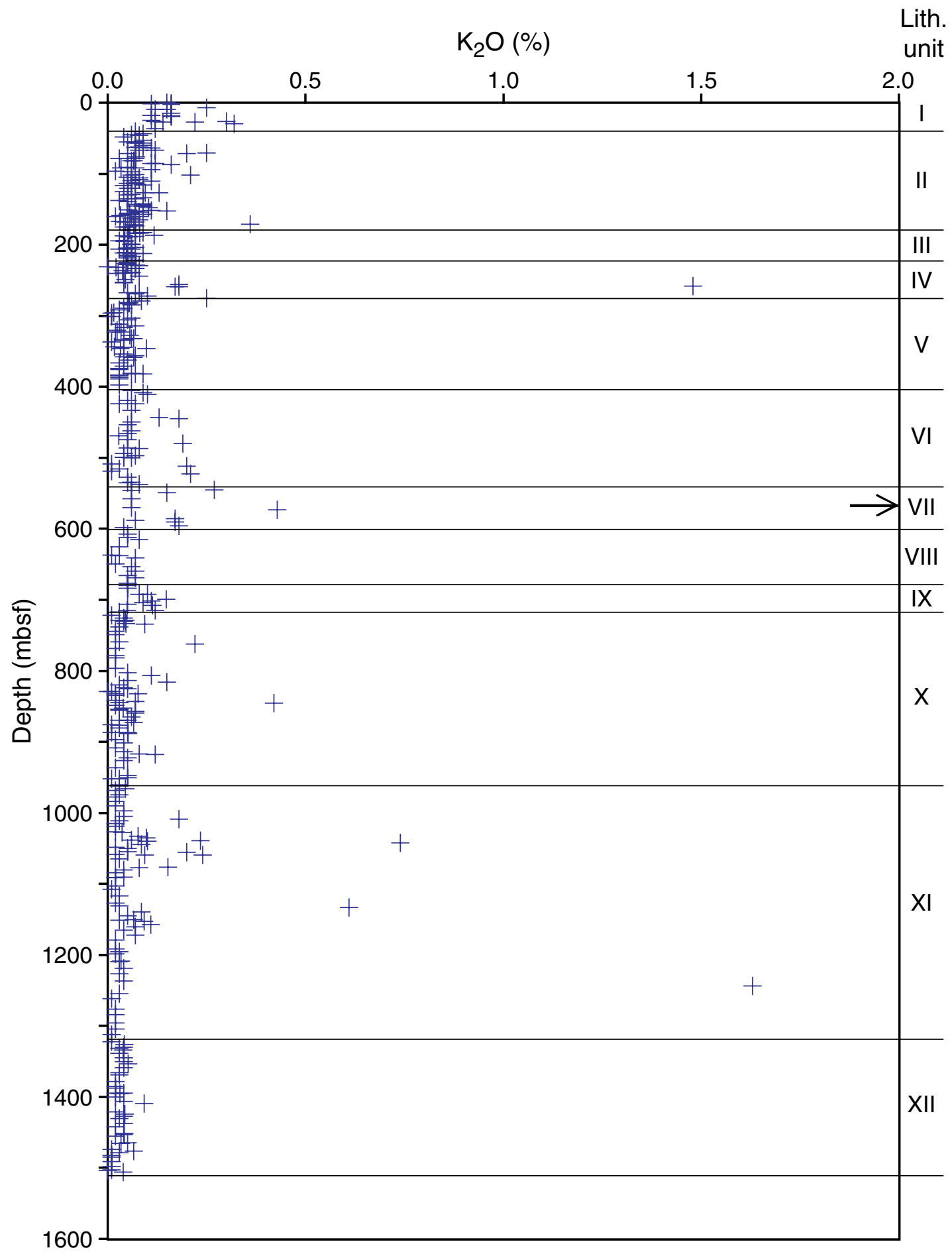


J. HerTOGEN ET AL.

Lithology, Mineralogy, AND Geochemistry of The LoWer OCEAN Crust

Figure F18. Downhole variation of $\mathrm{P}_{2} \mathrm{O}_{5}$ in Hole 735B. Roman numerals indicate the major lithologic units. $+=$ analyzed value. Arrows indicate values $>1.5 \mathrm{wt} \%$.

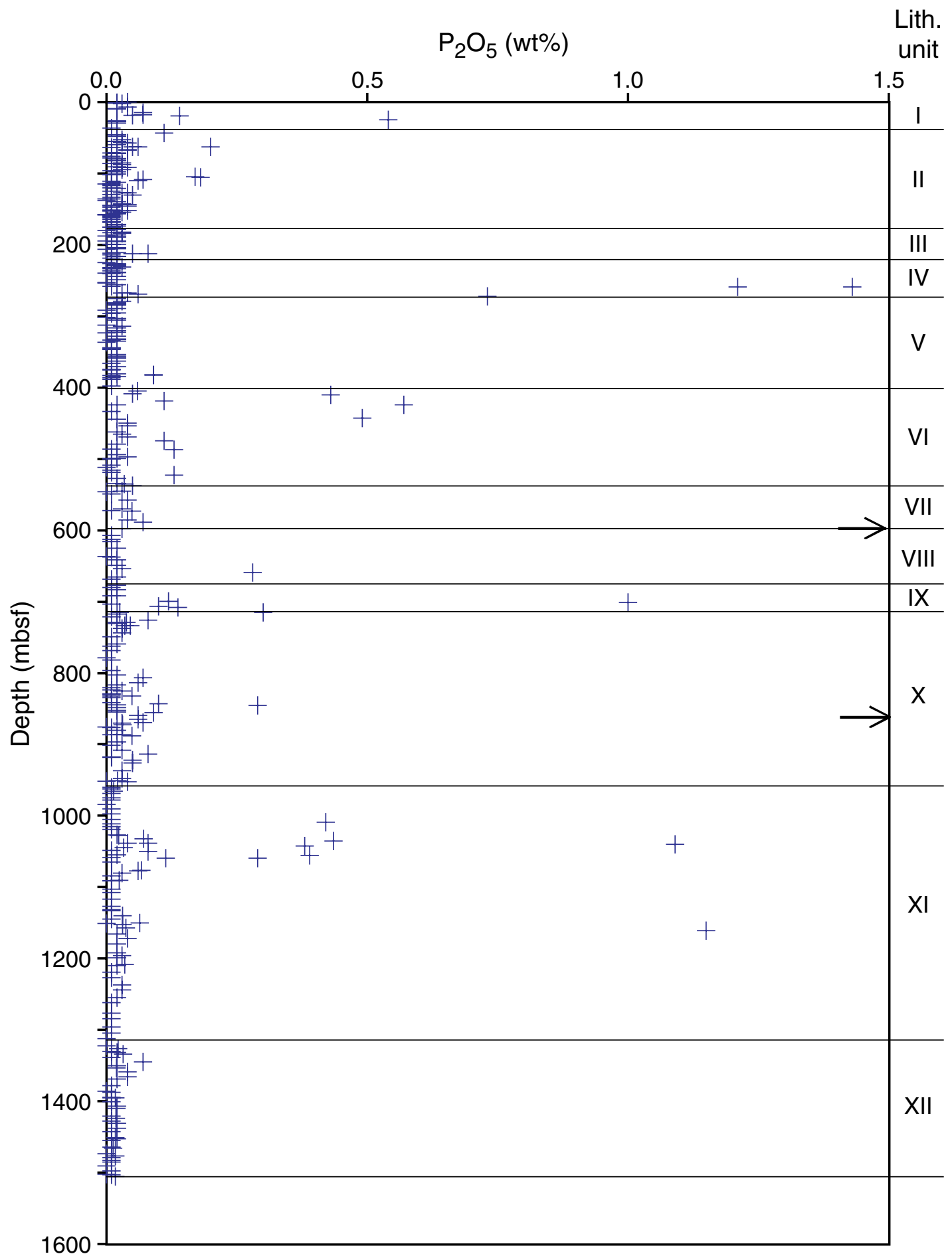


J. Hertogen ET AL.

Lithology, Mineralogy, AND Geochemistry of The LoWer OCEAN Crust

Figure F19. Downhole variation of $\mathrm{H}_{2} \mathrm{O}$ in Hole 735B. Roman numerals indicate the major lithologic units. $+=$ analyzed value. Arrows indicate values $>4.0 \mathrm{wt} \%$.

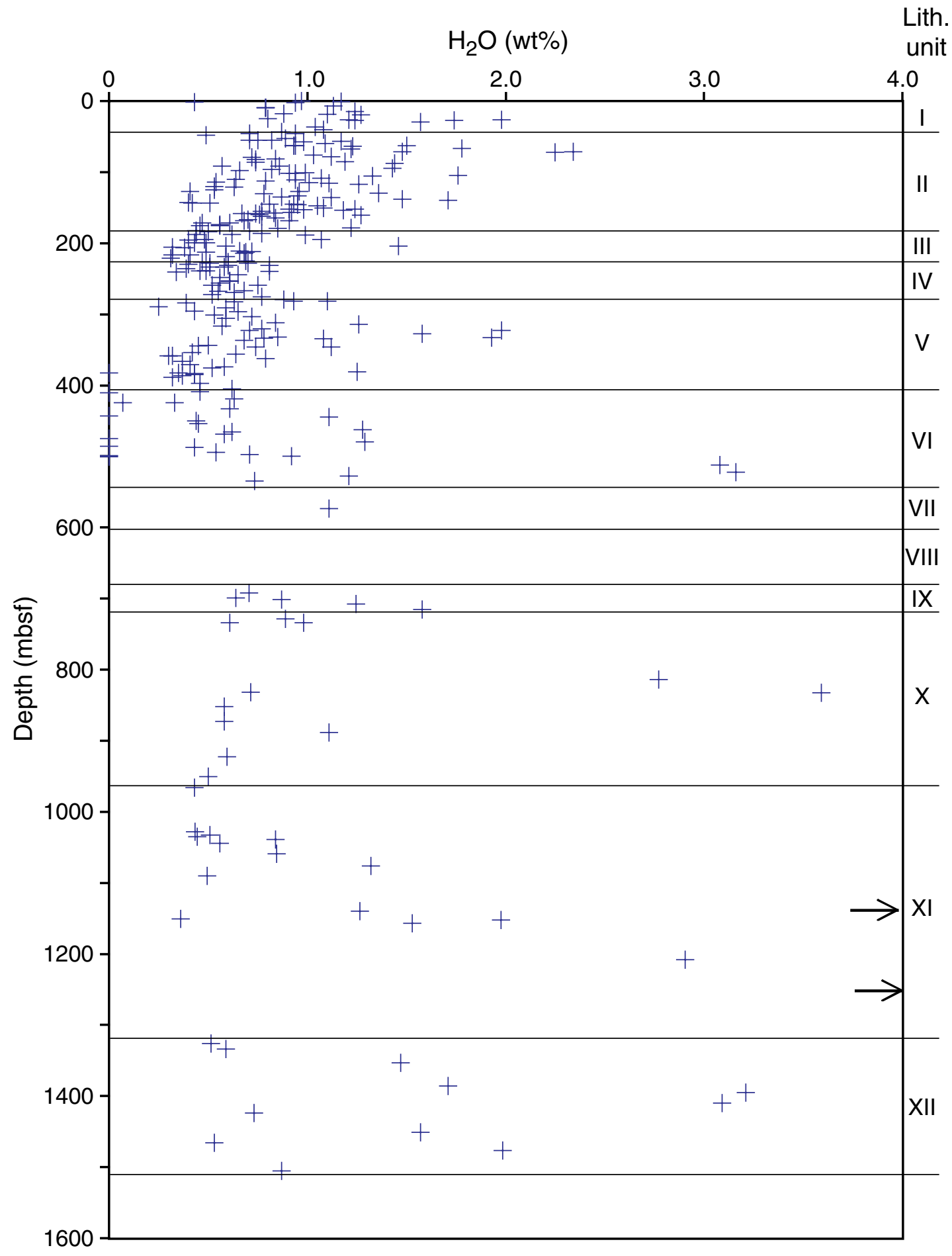


J. HerTOGEN ET AL.

Lithology, Mineralogy, AND Geochemistry of The LoWer OCEAN Crust

Figure F20. Downhole variation of $\mathrm{CO}_{2}$ in Hole 735B. Roman numerals indicate the major lithologic units. $+=$ analyzed value. Arrows indicate values $>2.0 \mathrm{wt} \%$.

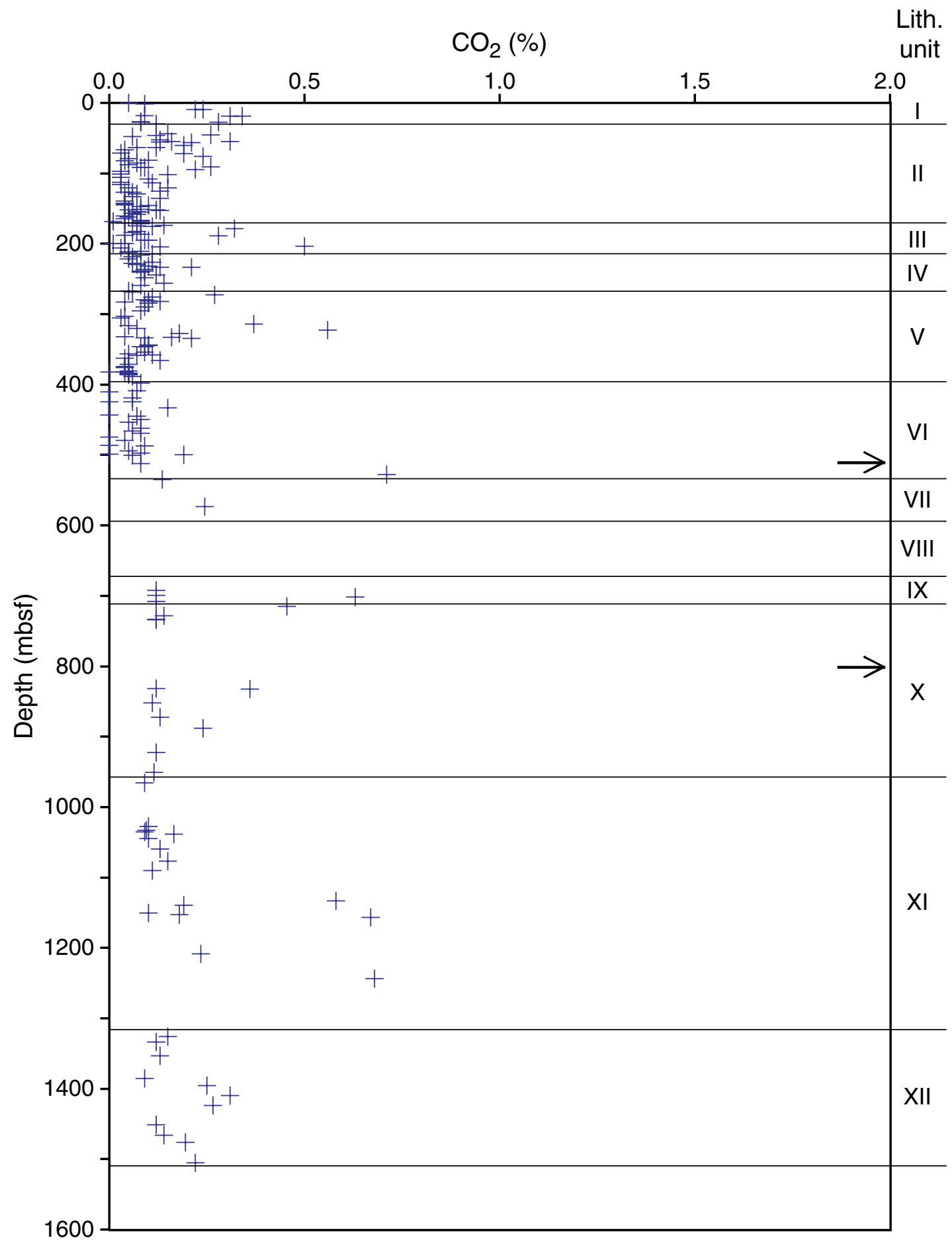


J. HerTOGEN ET AL.

Lithology, Mineralogy, AND Geochemistry of The LoWer OCEAN Crust

Figure F21. Downhole variation of $S$ in Hole 735B. Roman numerals indicate the major lithologic units. $+=$ analyzed value.

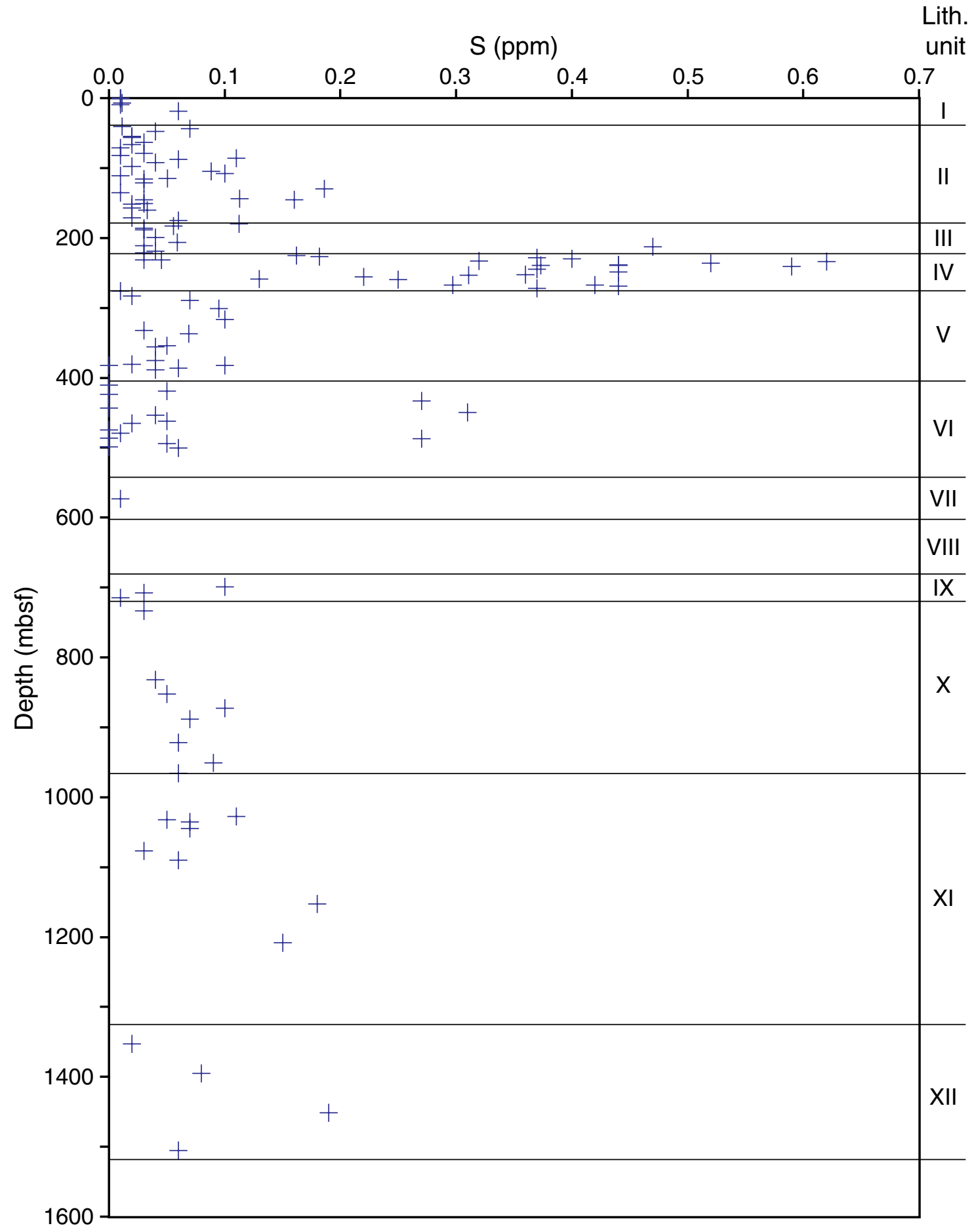


J. Hertogen ET AL.

Lithology, Mineralogy, AND Geochemistry of The LoWer OCEAN Crust

Figure F22. Downhole variation of V in Hole 735B. Roman numerals indicate the major lithologic units. $+=$ analyzed value. Arrow indicates a value $>1500 \mathrm{ppm}$.

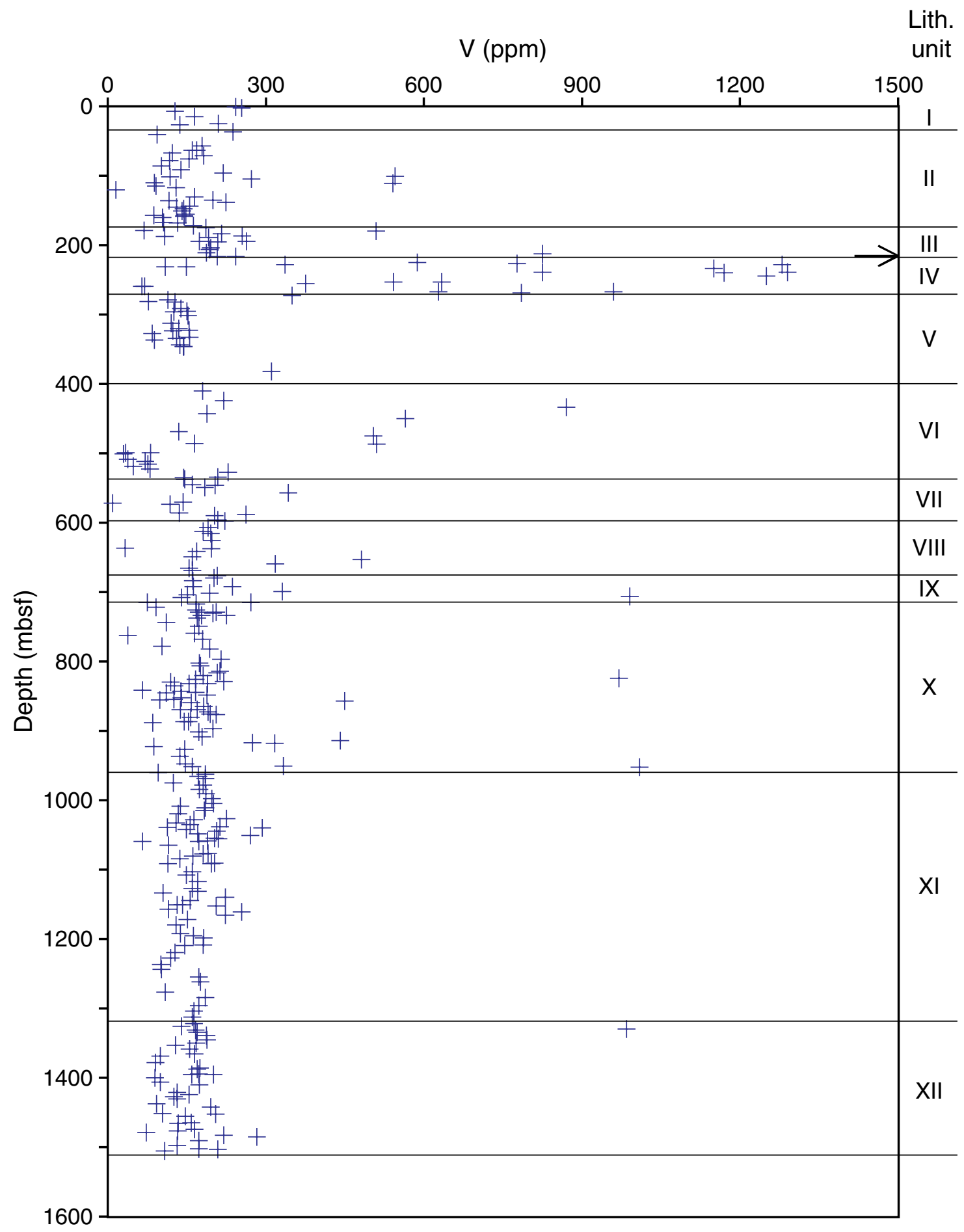




\section{J. HeRTogen ET AL.}

Lithology, Mineralogy, AND Geochemistry of The LoWer OCEAN Crust

Figure F23. Downhole variation of Ni in Hole 735B. Roman numerals indicate the major lithologic units. $+=$ analyzed value. Arrows indicate values $>600 \mathrm{ppm}$.

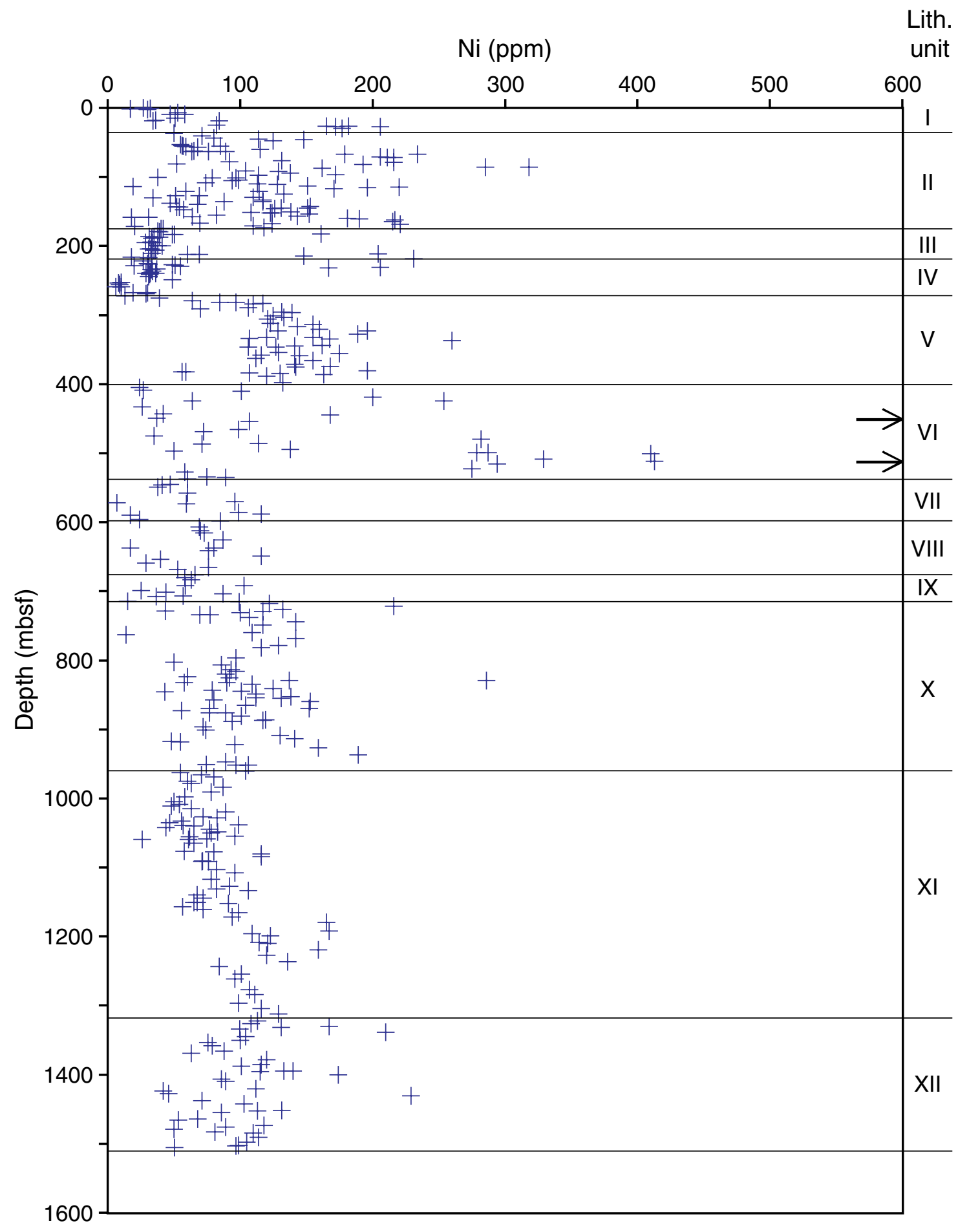




\section{J. HeRTOGEN ET AL.}

Lithology, Mineralogy, AND Geochemistry of the Lower OCEAn Crust

Figure F24. Downhole variation of $\mathrm{Cr}$ in Hole 735B. Roman numerals indicate the major lithologic units. $+=$ analyzed value. Arrow indicates a value $>1000 \mathrm{ppm}$.

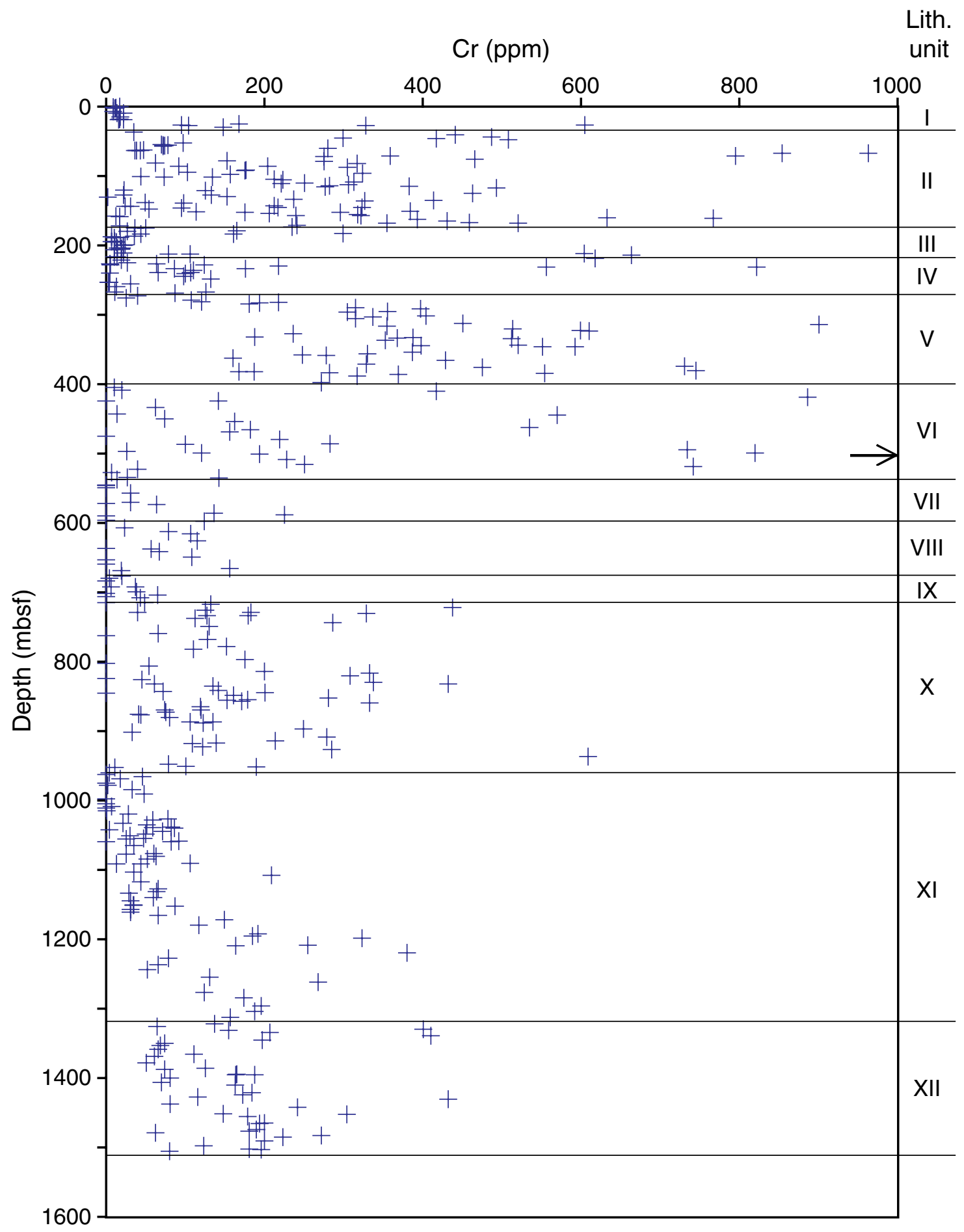


J. Hertogen ET AL.

Lithology, Mineralogy, AND Geochemistry of The LoWer OCEAN Crust

Figure F25. Downhole variation of $\mathrm{Zn}$ in Hole 735B. Roman numerals indicate the major lithologic units. $+=$ analyzed value.

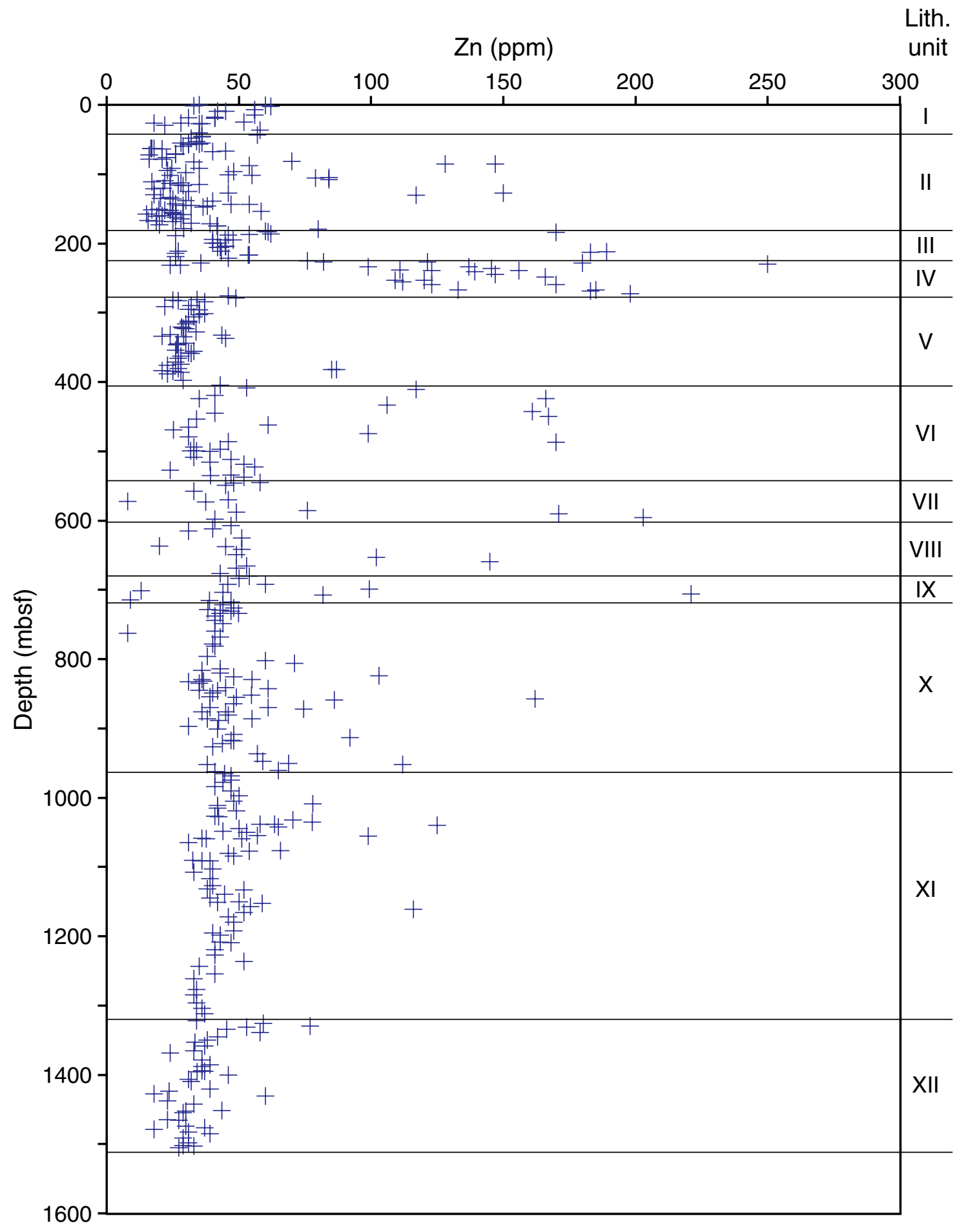


J. Hertogen ET AL.

Lithology, Mineralogy, AND Geochemistry of The LoWer OCEAN Crust

Figure F26. Downhole variation of $\mathrm{Cu}$ in Hole 735B. Roman numerals indicate the major lithologic units. $+=$ analyzed value. Arrow indicates a value $>300 \mathrm{ppm}$.

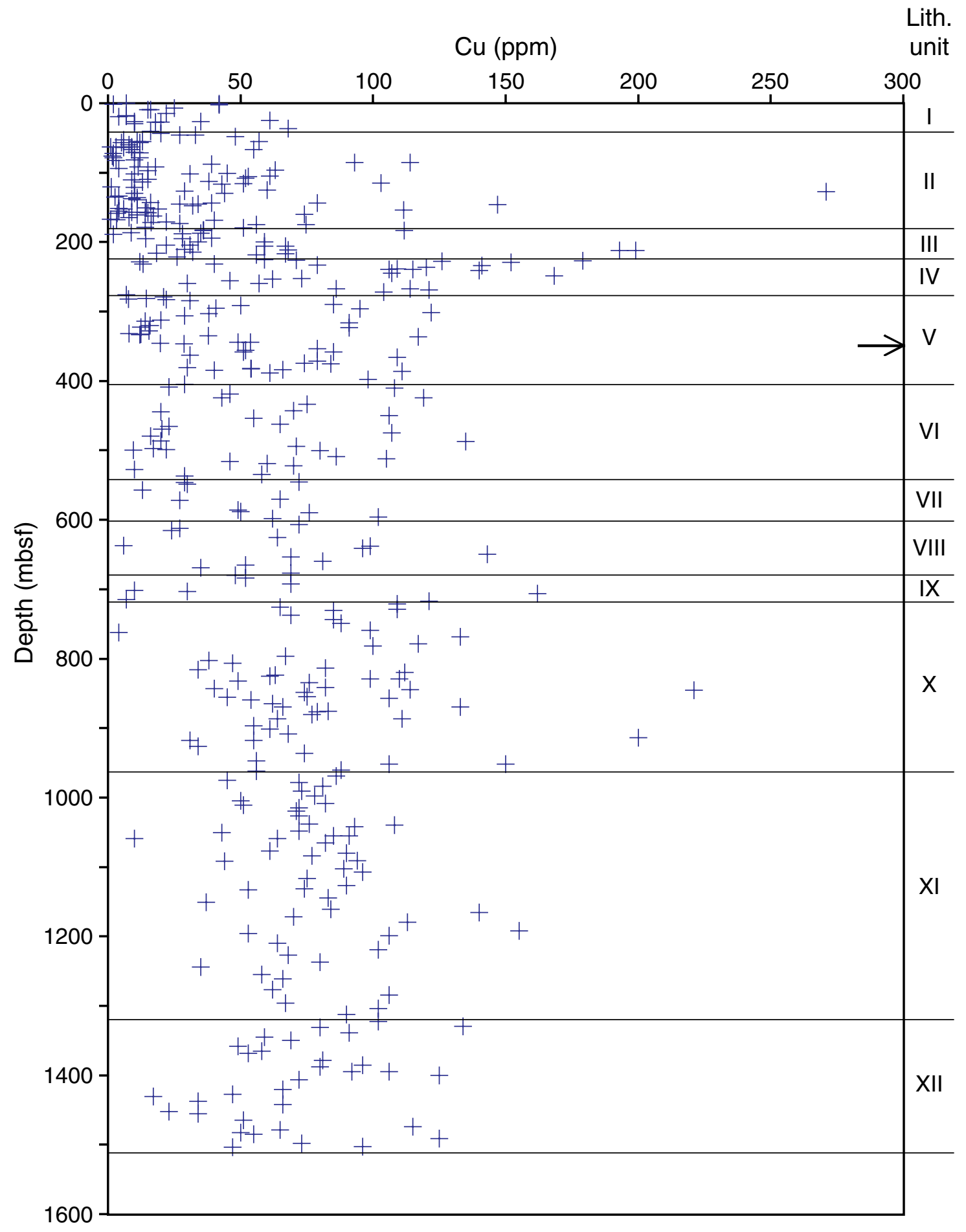


J. Hertogen ET AL.

Lithology, Mineralogy, AND Geochemistry of The LoWer OCEAN Crust

Figure F27. Downhole variation of $\mathrm{Y}$ in Hole 735B. Roman numerals indicate the major lithologic units. $+=$ analyzed value. Arrows indicate values $>150 \mathrm{ppm}$.

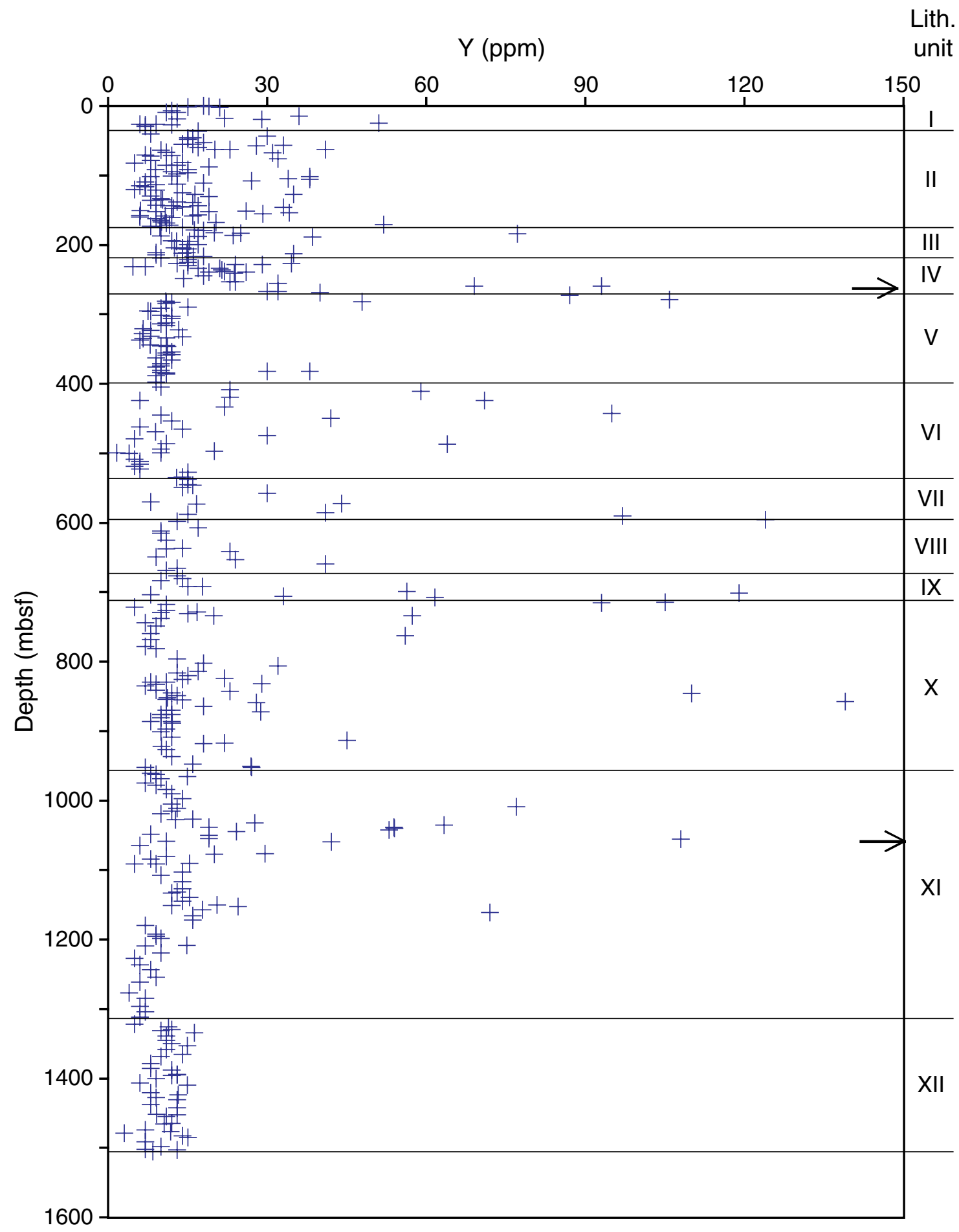


J. Hertogen ET AL.

Lithology, Mineralogy, AND Geochemistry of The LoWer OCEAN Crust

Figure F28. Downhole variation of $\mathrm{Zr}$ in Hole 735B. Roman numerals indicate the major lithologic units. $+=$ analyzed value. Arrows indicate values $>600 \mathrm{ppm}$.

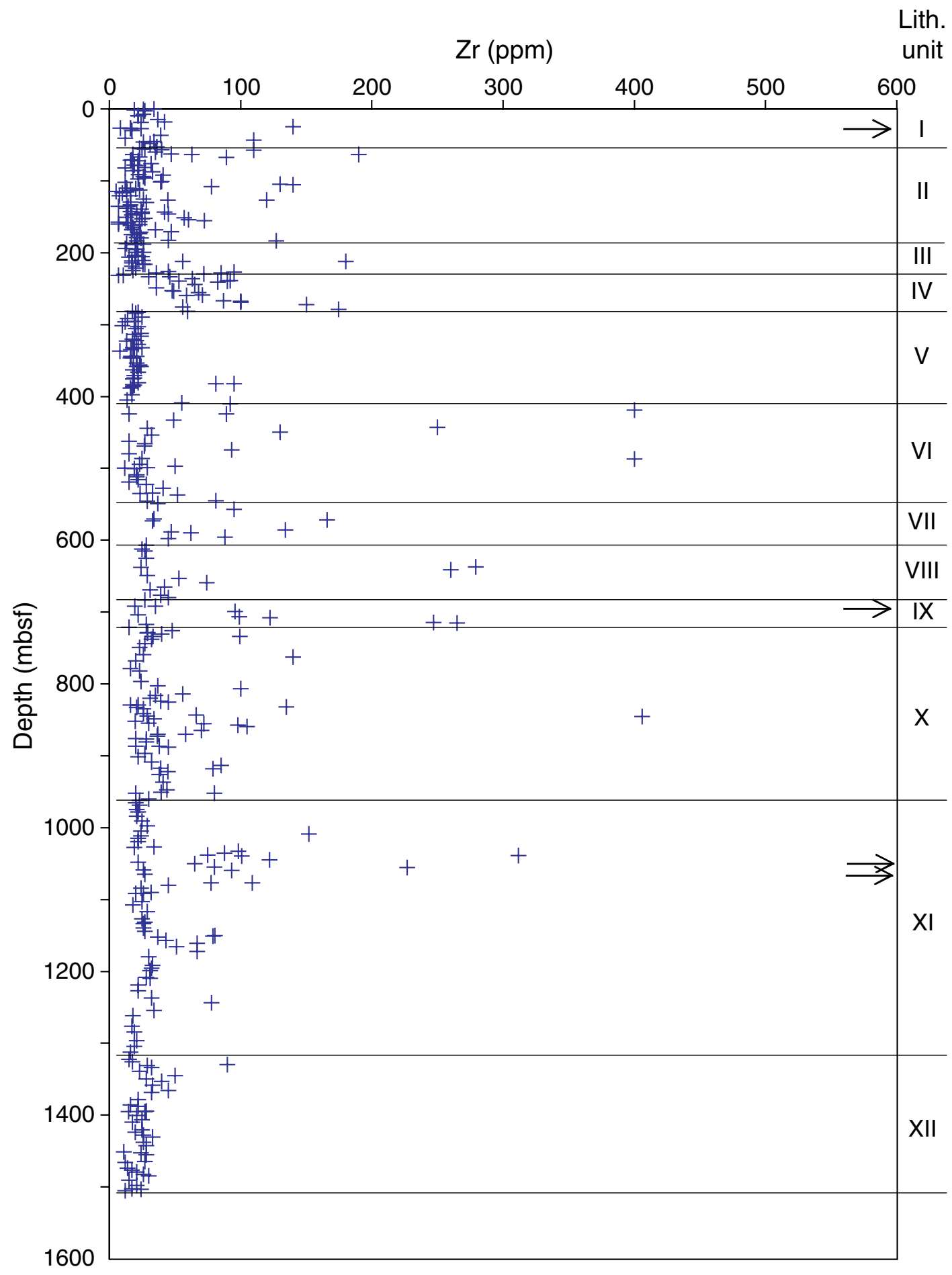


J. Hertogen ET AL.

Lithology, Mineralogy, AND Geochemistry of The LoWer OCEAN Crust

Figure F29. Downhole variation of $\mathrm{Sr}$ in Hole 735B. Roman numerals indicate the major lithologic units. $+=$ analyzed value.

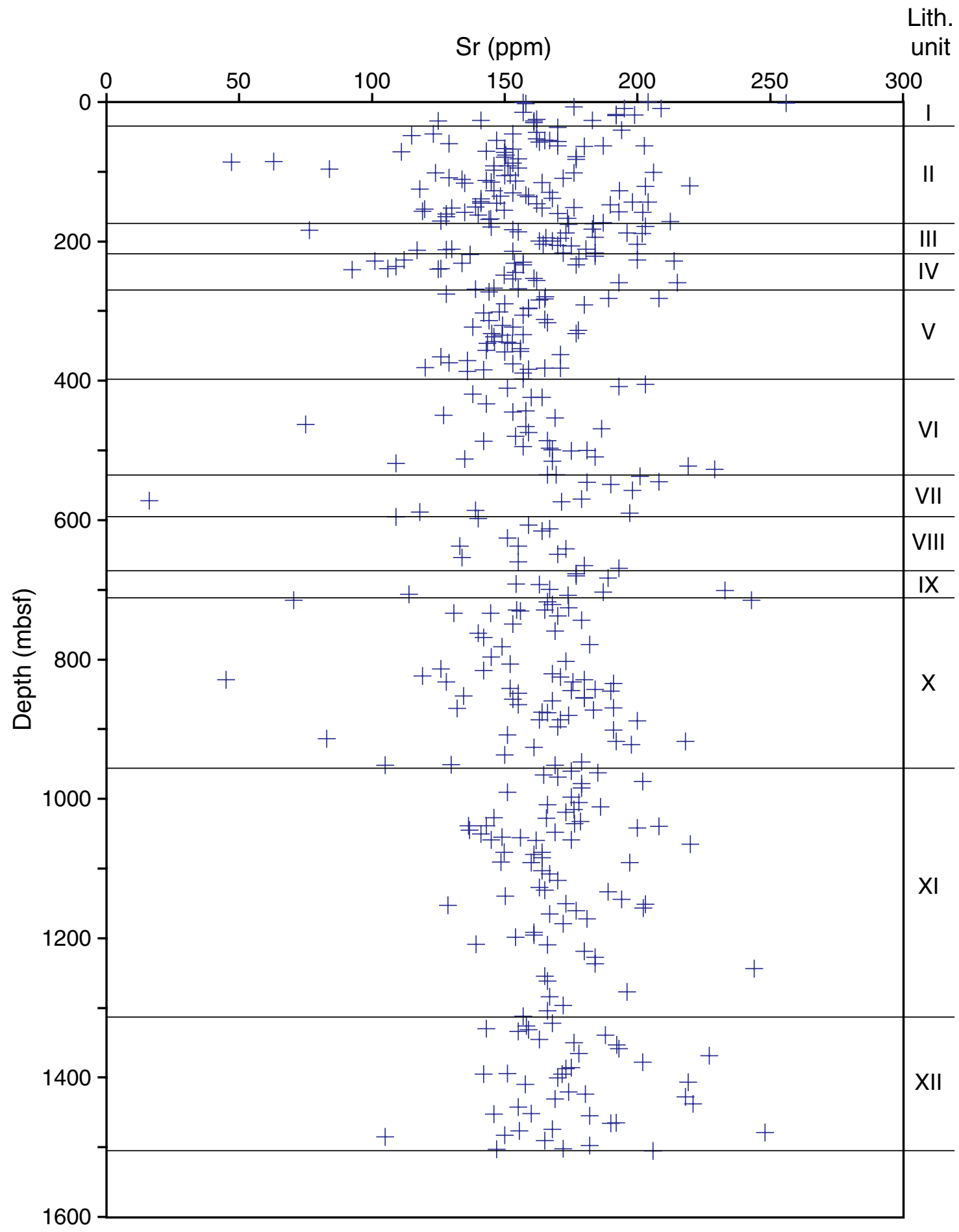


J. Hertogen eT AL.

Lithology, Mineralogy, AND Geochemistry of The LoWer Ocean Crust

57

Figure F30. Downhole variation of Sm (chondrite normalized) in Hole 735B.

$$
\text { Sm (chondrite normalized) }
$$

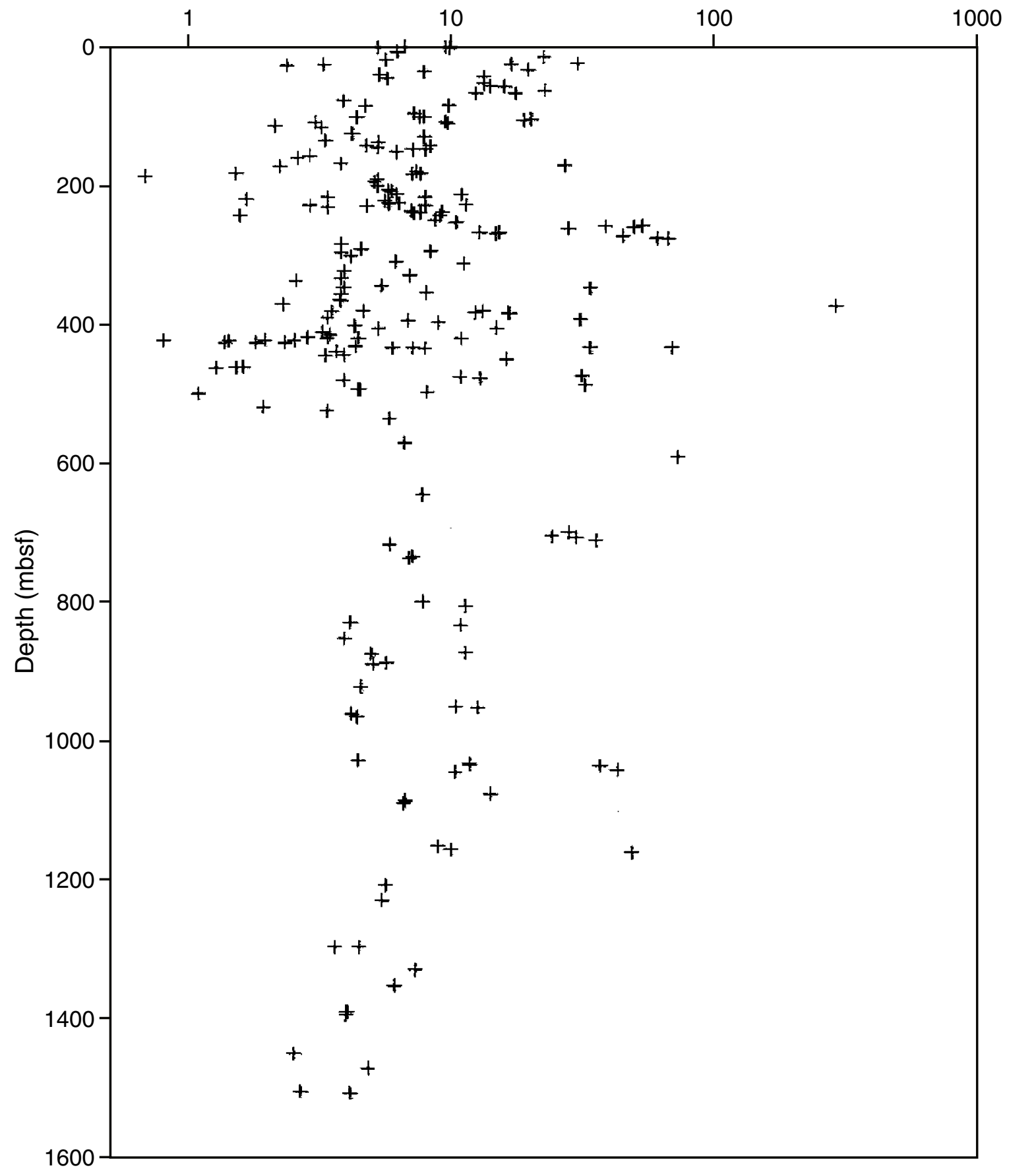


J. HERTOGEN ET AL.

Lithology, Mineralogy, AND Geochemistry of The LoWer OCEAN Crust

Figure F31. Downhole variation of $\mathrm{La} / \mathrm{Yb}$ (chondrite normalized) in Hole 735B.

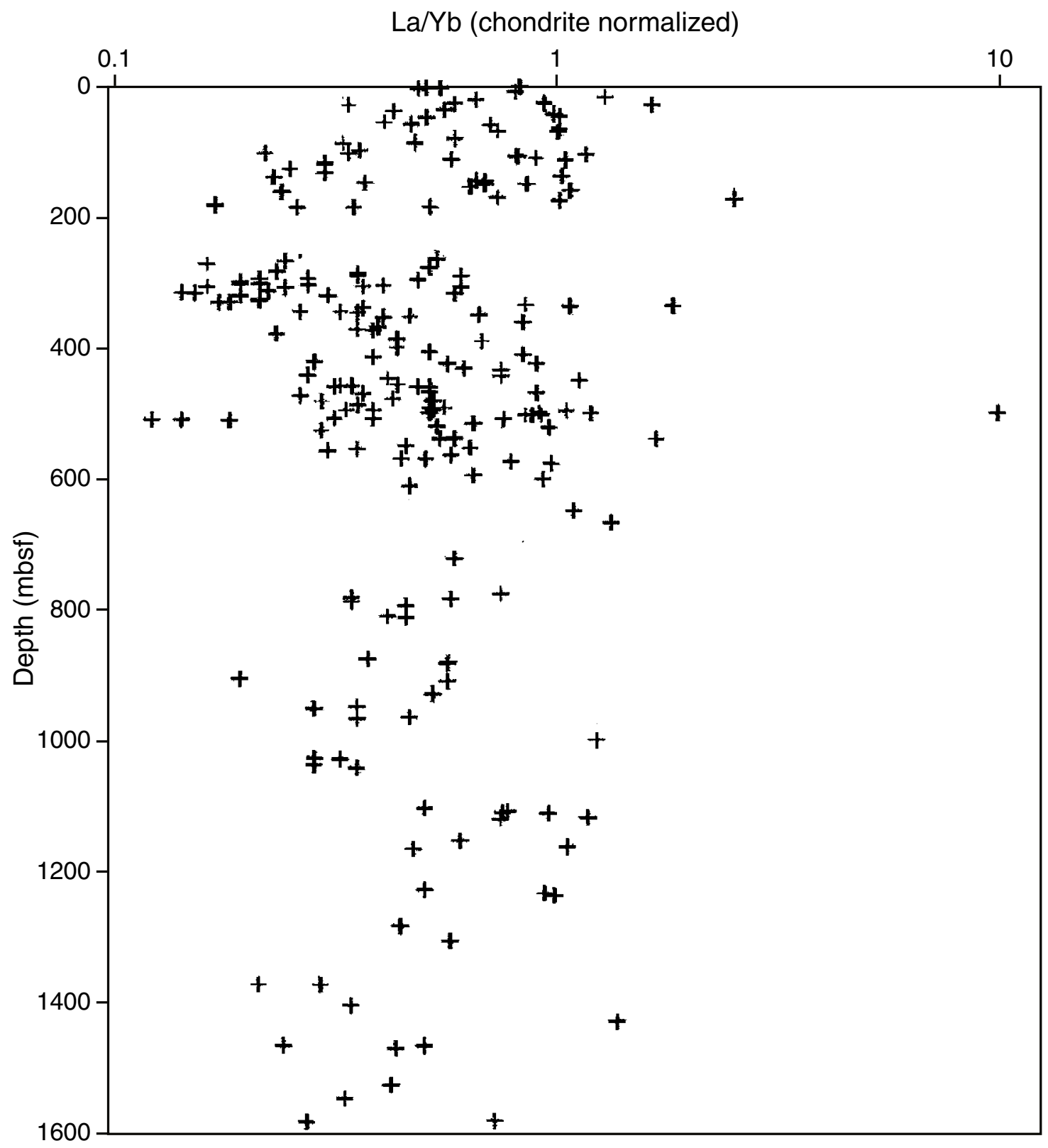


J. HeRTOGEN ET AL.

Lithology, Mineralogy, AND Geochemistry of The LoWer OCEAn Crust

Figure F32. Chondrite-normalized REE plots of representative samples from Hole 735B. $\mathrm{Gd}^{*}=$ calculated value.

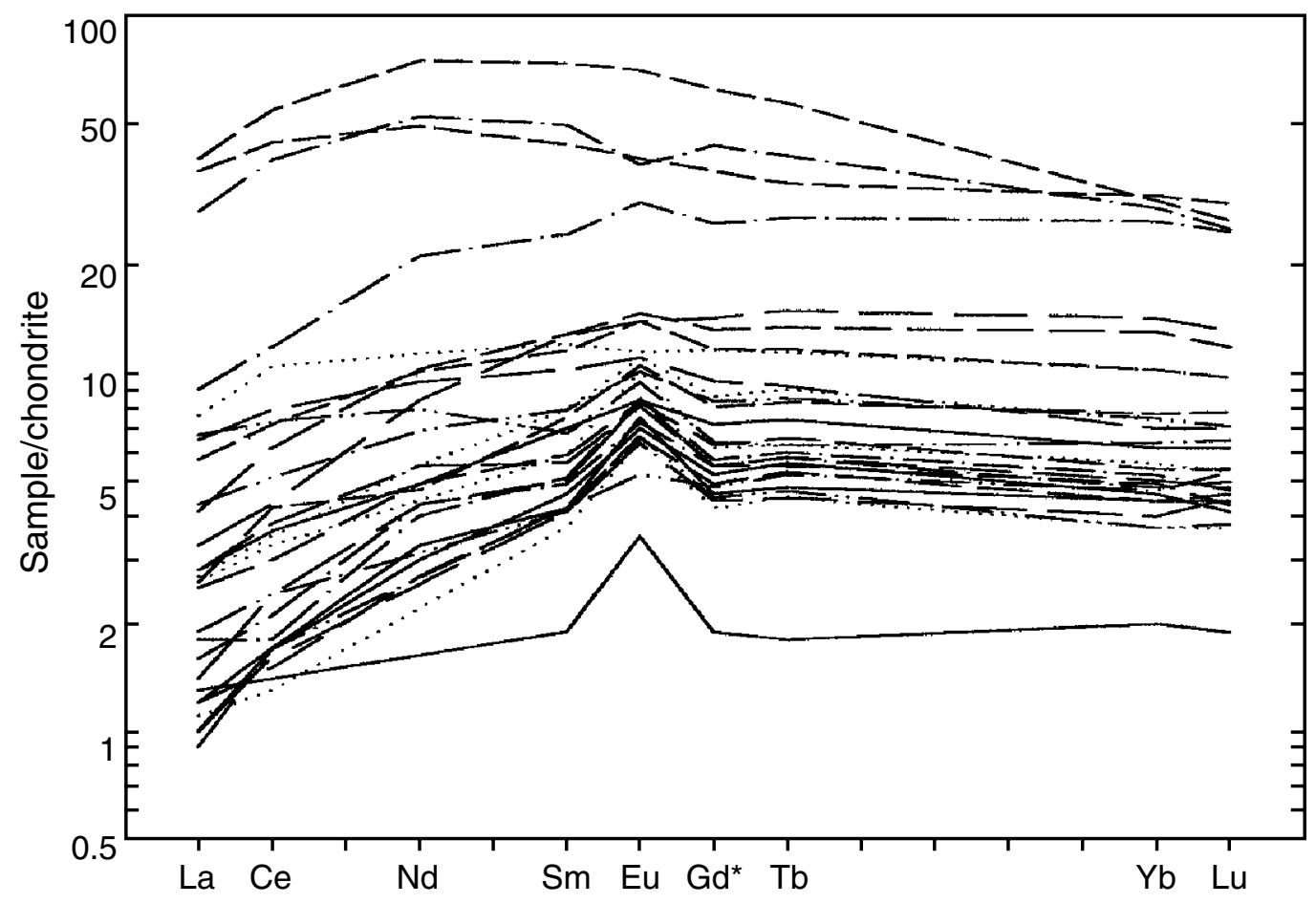


J. HERTOGEN ET AL.

Lithology, Mineralogy, ANd Geochemistry of The Lower OCEAN Crust

Figure F33. Plot of $\mathrm{La} / \mathrm{Yb}$ (chondrite normalized) vs. $\mathrm{Yb}$ (chondrite normalized) for samples from Hole 735B. MORB = mid-ocean-ridge basalt.

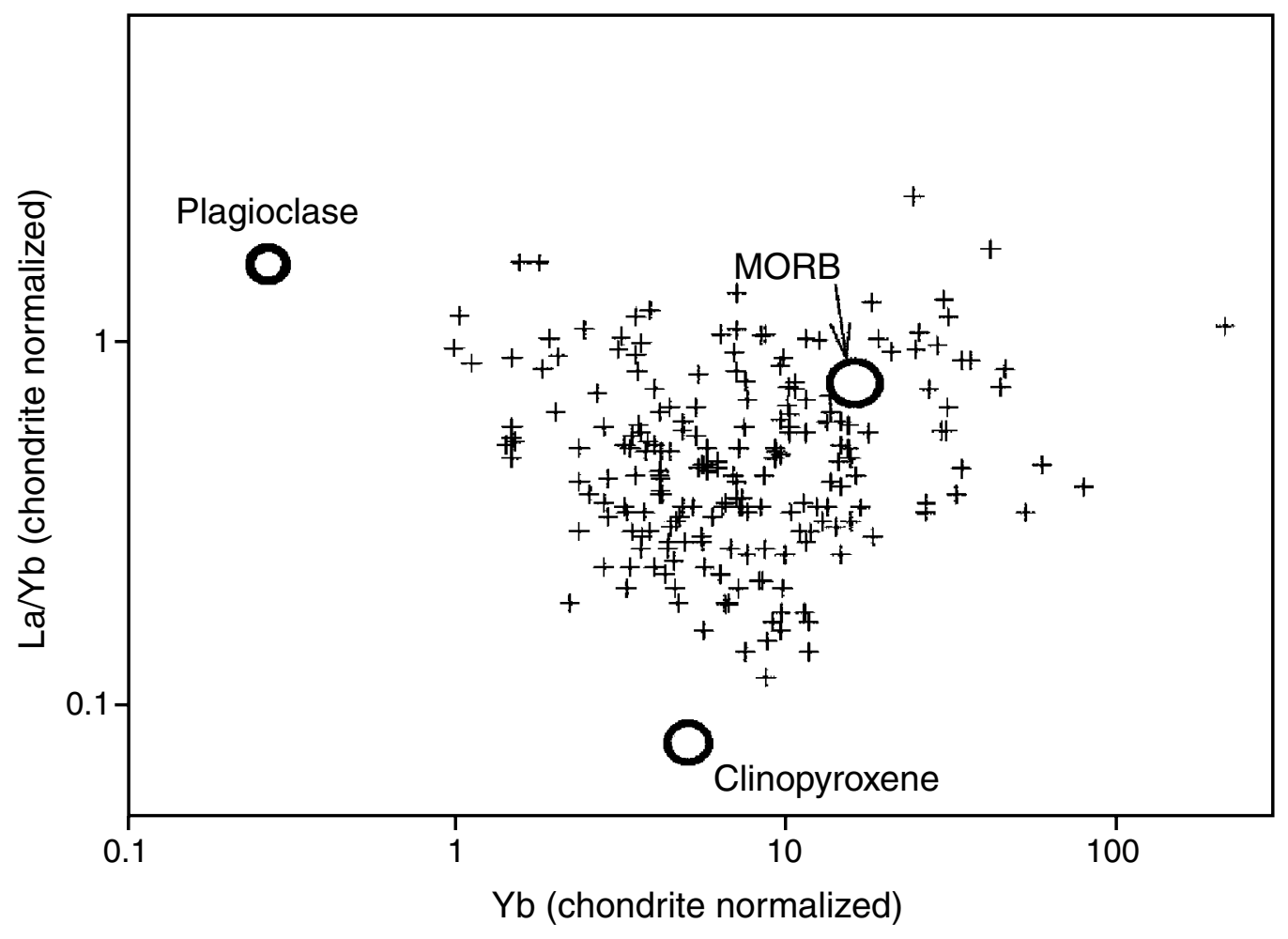


J. HERTOGEN ET AL.

Lithology, Mineralogy, AND Geochemistry of THE LoWER OCEAN CRUST

Table T1. Average primary modal compositions of major lithologies, Hole 735B.

\begin{tabular}{|c|c|c|c|c|c|c|c|c|}
\hline Rock type: & $\begin{array}{c}\text { Number of } \\
\text { analyses }\end{array}$ & Plagioclase & Olivine & Clinopyroxene & Orthopyroxene & Opaques & Amphibole & Apatite \\
\hline Troctolite & 9 & 66.6 & 29.6 & 3.4 & 0.2 & 0.2 & 0.1 & $\operatorname{Tr}$ \\
\hline Troctolitic microgabbro & 14 & 72.2 & 16.6 & 10.7 & 0.1 & 0.2 & 0.2 & $\operatorname{Tr}$ \\
\hline Olivine gabbro & 145 & 59.0 & 9.8 & 30.5 & 0.2 & 0.3 & 0.3 & $\operatorname{Tr}$ \\
\hline Olivine microgabbro & 15 & 57.2 & 9.7 & 32.6 & 0.1 & 0.1 & 0.3 & $\operatorname{Tr}$ \\
\hline Gabbro & 25 & 58.4 & 3.3 & 37.4 & 0.2 & 0.4 & 0.3 & $\operatorname{Tr}$ \\
\hline Gabbronorite & 17 & 64.3 & 2.5 & 27.2 & 4.3 & 1.0 & 0.8 & $\operatorname{Tr}$ \\
\hline Fe-Ti oxide gabbro & 9 & 45.1 & 1.7 & 39.5 & 0.7 & 12.2 & 0.6 & 0.2 \\
\hline Fe-Ti oxide microgabbro & 5 & 58.5 & 10.9 & 25.8 & 1.5 & 1.8 & 1.4 & 0.1 \\
\hline Fe-Ti oxide gabbronorite & 32 & 49.2 & 1.0 & 35.4 & 3.0 & 10.6 & 0.5 & 0.4 \\
\hline
\end{tabular}

Notes: All data based on point counting of thin sections (Robinson, von Herzen, et al., 1989; Shipboard Scientific Party, 1999; Dick, Natland, Miller, et al., 1999). Tr = trace. 
J. HeRTOGEN ET AL.

Lithology, Mineralogy, ANd Geochemistry of The Lower OCEAN Crust

Table T2. Modal data by X-ray diffraction analysis. (See table notes. Continued on next page.)

\begin{tabular}{|c|c|c|c|c|c|c|c|c|c|c|c|}
\hline $\begin{array}{l}\text { Core, section, } \\
\text { interval }(\mathrm{cm})\end{array}$ & $\begin{array}{l}\text { Depth } \\
\text { (mbsf) }\end{array}$ & Plagioclase & Clinopyroxene & Orthopyroxene & Olivine & Amphibole & Chlorite & Ilmenite & Magnetite & Other & $\begin{array}{l}\text { Possible } \\
\text { minerals }\end{array}$ \\
\hline \multicolumn{12}{|l|}{ 118-735B- } \\
\hline 1D-1, 1-6 & 0.1 & 51 & 6 & & & 43 & & & & & \\
\hline 1D-1, 117-120 & 1.2 & 67 & 3 & & & 30 & & & & & \\
\hline $4 \mathrm{D}-1,69-75$ & 18.2 & 68 & 9 & & & 22 & & & & 1 & \\
\hline 7D-1, 137-143 & 27.4 & 59 & 0 & & 9 & 27 & 3 & & & 2 & \\
\hline $12 \mathrm{R}-3,127-132$ & 43.7 & 47 & 28 & & & 25 & & & & & \\
\hline $14 \mathrm{R}-2,42-47$ & 52.7 & 47 & 22 & & & 31 & & & & & \\
\hline $16 \mathrm{R}-1,80-86$ & 62.6 & 53 & 0 & & & 47 & & & & & \\
\hline $18 \mathrm{R}-2,102-106$ & 71.0 & 34 & 0 & & & 50 & 12 & & & 4 & \\
\hline $19 \mathrm{R}-3,115-123$ & 78.8 & 54 & 25 & & 9 & 11 & & & 1 & & \\
\hline $20 \mathrm{R}-3,48-53$ & 87.5 & 40 & 6 & & & 47 & 4 & & 3 & & \\
\hline $21 \mathrm{R}-3,26-32$ & 91.9 & 51 & 27 & & & 18 & 4 & & & & \\
\hline $23 R-1,36-39$ & 100.9 & 65 & 5 & & & 16 & 5 & 7 & & 2 & \\
\hline $23 \mathrm{R}-2,42-48$ & 101.6 & 28 & 10 & & & 54 & & 8 & & & \\
\hline $23 R-5,3-5$ & 105.6 & 44 & 30 & & & 15 & 7 & & 1 & 3 & \\
\hline $24 \mathrm{R}-2,126-132$ & 108.3 & 37 & 15 & & & 45 & & & 3 & & \\
\hline $26 \mathrm{R}-1,6-12$ & 115.6 & 60 & 16 & & 6 & 13 & 3 & & & 2 & \\
\hline $28 \mathrm{R}-1,45-51$ & 127.0 & 47 & 23 & & & 30 & & & & & \\
\hline $30 \mathrm{R}-2,138-144$ & 139.3 & 48 & 27 & & & 12 & 13 & & & & \\
\hline $31 \mathrm{R}-2,19-25$ & 145.2 & 54 & 25 & & 8 & 9 & 2 & & & 2 & \\
\hline $31 \mathrm{R}-2,77-81$ & 145.8 & 55 & & & & 41 & & 3 & 1 & & \\
\hline $32 \mathrm{R}-3,54-60$ & 151.7 & 62 & 15 & & 4 & 17 & 2 & & & & \\
\hline $34 \mathrm{R}-3,97-105$ & 162.3 & 53 & 28 & & 9 & 10 & & & & & \\
\hline $35 R-6,36-43$ & 171.1 & 61 & 18 & & & 17 & & & & 4 & \\
\hline $36 \mathrm{R}-2,98-102$ & 173.5 & 73 & 11 & & 8 & 8 & & & & & \\
\hline $38 \mathrm{R}-2,24-36$ & 182.5 & 54 & 23 & & 18 & 5 & & & & & \\
\hline $41 \mathrm{R}-4,22-27$ & 199.5 & 57 & 29 & & 4 & 10 & & & & & \\
\hline $44 \mathrm{R}-2,24-34$ & 212.5 & 40 & 23 & & & 10 & 4 & 17 & 6 & & \\
\hline $45 R-3,16-24$ & 218.7 & 45 & 36 & & 11 & & 1 & & & 7 & \\
\hline $47 \mathrm{R}-3,62-68$ & 229.6 & 54 & 14 & & & 7 & 3 & 10 & 12 & & \\
\hline $48 \mathrm{R}-2,109-113$ & 233.4 & 54 & 30 & & & 7 & 2 & 4 & 3 & & \\
\hline 50R-1, 82-90 & 238.8 & 42 & 29 & & & 10 & & 15 & 4 & & \\
\hline 50R-2, 25-33 & 239.2 & 35 & 27 & & & 11 & & 19 & 4 & 4 & \\
\hline $51 \mathrm{R}-2,16-25$ & 244.4 & 44 & 16 & & & 13 & 5 & 12 & 7 & 3 & \\
\hline $53 \mathrm{R}-3,30-37$ & 255.8 & 51 & 18 & & & 21 & & & 3 & 7 & \\
\hline $54 \mathrm{R}-1,121-130$ & 259.2 & 65 & 18 & & & 8 & 2 & 2 & & 5 & \\
\hline $55 \mathrm{R}-2,67-75$ & 267.2 & 47 & 31 & & & 16 & & 2 & 4 & & \\
\hline $55 R-3,91-97$ & 268.9 & 43 & 28 & & & 12 & & 9 & 6 & 2 & \\
\hline $57 \mathrm{R}-1,68-78$ & 275.7 & 61 & 13 & & & 26 & & & & & \\
\hline $58 \mathrm{R}-2,106-116$ & 282.8 & 58 & 27 & & 7 & 7 & & & 1 & & \\
\hline $62 \mathrm{R}-4,144-150$ & 305.8 & 50 & 29 & & 12 & 9 & & & & & \\
\hline $63 \mathrm{R}-7,19-25$ & 313.9 & 52 & 33 & & & 12 & 3 & & & & \\
\hline $67 \mathrm{R}-3,74-78$ & 333.6 & 61 & 28 & & & 9 & 2 & & & & \\
\hline $73 R-7,50-60$ & 374.3 & 47 & 41 & & 10 & & & & & 2 & \\
\hline $74 \mathrm{R}-6,45-52$ & 382.2 & 54 & 30 & 7 & & 2 & & 3 & 3 & 1 & \\
\hline $75 R-2,54-56$ & 386.3 & 51 & 40 & & 9 & & & & & & \\
\hline $75 R-4,0-20$ & 388.6 & 57 & 35 & & 8 & & & & & & \\
\hline $77 R-4,74-82$ & 408.7 & 64 & 32 & & & 4 & & & & & \\
\hline 79R-4, 18-28 & 419.1 & 58 & 27 & & 11 & 4 & & & & & \\
\hline 79R-7, 111-119 & 424.2 & 60 & 9 & & 26 & 3 & & & & 2 & \\
\hline $82 \mathrm{R}-2,17-23$ & 444.7 & 60 & 11 & & 9 & 12 & 4 & & & 4 & \\
\hline $83 \mathrm{R}-1,122-131$ & 453.7 & 54 & 29 & & 12 & 5 & & & & & \\
\hline $83 R-7,113-120$ & 462.4 & 23 & 6 & & 59 & 8 & & & & 4 & \\
\hline $84 R-3,66-76$ & 465.6 & 52 & 31 & & 5 & 12 & & & & & \\
\hline $85 R-5,68-77$ & 477.9 & 24 & 19 & & & 31 & 6 & 13 & 4 & 3 & \\
\hline $85 \mathrm{R}-6,115-124$ & 479.6 & 64 & 5 & & 19 & 9 & 2 & & & 1 & \\
\hline $86 \mathrm{R}-5,29-38$ & 487.1 & 46 & 34 & & & 13 & & 2 & 5 & & \\
\hline 87R-3, 94-104 & 494.3 & 56 & 28 & & 12 & 4 & & & & & \\
\hline $87 R-5,87-96$ & 497.2 & 60 & 23 & & 6 & 11 & & & & & \\
\hline \multicolumn{12}{|l|}{ 176-735B- } \\
\hline $91 \mathrm{R}-5,81-86$ & 525.2 & 84 & 16 & & & & & & & & Calcite \\
\hline $93 R-3,105-110$ & 534.9 & 67 & 28 & & 5 & & & & & & \\
\hline $99 \mathrm{R}-4,70-75$ & 573.4 & 68 & 18 & & & 14 & & & & & \\
\hline $118 \mathrm{R}-1,135-140$ & 692.0 & 56 & 38 & & & 6 & & & & & \\
\hline $118 \mathrm{R}-6,100-105$ & 699.3 & 61 & 30 & & & 9 & & & & & \\
\hline $119 R-5,62-68$ & 707.9 & 66 & 20 & & & 14 & & & & & \\
\hline $120 \mathrm{R}-1,85-91$ & 710.9 & 29 & 46 & & & 25 & & & & & \\
\hline $121 \mathrm{R}-8,1-8$ & 728.7 & 53 & 41 & & & 5 & 1 & & & & \\
\hline $122 \mathrm{R}-3,135-139$ & 733.8 & 45 & 50 & & & 5 & & & & & \\
\hline
\end{tabular}


J. Hertogen eT AL.

Lithology, Mineralogy, ANd Geochemistry of The LoWer OCEAN Crust

Table T2 (continued).

\begin{tabular}{|c|c|c|c|c|c|c|c|c|c|c|c|}
\hline $\begin{array}{l}\text { Core, section, } \\
\text { interval }(\mathrm{cm})\end{array}$ & $\begin{array}{l}\text { Depth } \\
\text { (mbsf) }\end{array}$ & Plagioclase & Clinopyroxene & Orthopyroxene & Olivine & Amphibole & Chlorite & Ilmenite & Magnetite & Other & $\begin{array}{l}\text { Possible } \\
\text { minerals }\end{array}$ \\
\hline $122 \mathrm{R}-4,0-5$ & 733.9 & 59 & 30 & & & 11 & & & & & \\
\hline 133R-7, 95-100 & 832.1 & 65 & 30 & & & 5 & & & & & \\
\hline $137 R-1,45-49$ & 852.3 & 55 & 34 & & 10 & & & & & 1 & \\
\hline 139R-2, 0-5 & 872.6 & 76 & 24 & & & & & & & & \\
\hline $140 \mathrm{R}-6,40-44$ & 888.2 & 47 & 37 & & 3 & 12 & 1 & & & & \\
\hline 145R-1, 37-46 & 922.3 & 79 & 16 & & 5 & & & & & & \\
\hline $149 \mathrm{R}-4,82-87$ & 965.8 & 61 & 30 & & 4 & 5 & & & & & \\
\hline 156R-3, 7-13 & 1027.8 & 61 & 31 & & 5 & 3 & & & & & \\
\hline $156 \mathrm{R}-6,42-46$ & 1032.6 & 70 & 21 & & 5 & 4 & & & & & \\
\hline 157R-1, 104-111 & 1035.3 & 68 & 25 & & & 7 & & & & & \\
\hline $157 R-4,0-7$ & 1038.8 & 65 & 19 & & & 16 & & & & & \\
\hline 158R-1，69-75 & 1044.7 & 47 & 40 & & 5 & 8 & & & & & \\
\hline $159 \mathrm{R}-4,120-125$ & 1059.4 & 61 & 31 & & & 8 & & & & & \\
\hline $161 \mathrm{R}-3,128-135$ & 1076.6 & 54 & 26 & & & 19 & 1 & & & & \\
\hline 168R-7, 131-135 & 1139.7 & 51 & 43 & 5 & & & & & & 1 & Chlorite \\
\hline 170R-1, 117-122 & 1150.5 & 68 & 26 & & 6 & & & & & & \\
\hline 170R-3, 15-21 & 1152.5 & 44 & 56 & & & & & & & & Chlorite \\
\hline $170 \mathrm{R}-6,26-32$ & 1157.1 & 71 & 29 & & & & & & & & Chlorite \\
\hline 177R-5, 70-76 & 1208.4 & 55 & 45 & & & & & & & & Chlorite \\
\hline 189R-7, 75-81 & 1326.1 & 66 & 25 & & 9 & & & & & & \\
\hline $190 \mathrm{R}-6,42-48$ & 1334.6 & 62 & 34 & & 4 & & & & & & \\
\hline $192 R-6,44-50$ & 1353.2 & 57 & 22 & & & 20 & 1 & & & & \\
\hline 199R-3, 1-6 & 1395.4 & 58 & 41 & & & & 1 & & & & Chlorite \\
\hline $200 R-6,31-37$ & 1409.8 & 31 & 69 & & & & & & & & Chlorite \\
\hline $202 \mathrm{R}-2,123-128$ & 1423.9 & 62 & 38 & & & & & & & & Chlorite \\
\hline 205R-1, 123-128 & 1451.4 & 65 & 21 & & 7 & 6 & 1 & & & & Chlorite \\
\hline 206R-4, 139-144 & 1465.8 & 74 & 26 & & & & & & & & \\
\hline 207R-5, 76-81 & 1476.3 & 62 & 38 & & & & & & & & Chlorite \\
\hline $210 \mathrm{R}-5,116-120$ & 1505.5 & 75 & 24 & & & & & & & 1 & \\
\hline
\end{tabular}

Notes: All values in modal percent. ? = possibly present, blank = below detection limit. 
J. HERTOGEN ET AL.

Lithology, Mineralogy, AND GEOChemistry of The LOWER OCEAN CRUST

Table T3. Average modal analyses of lithologic units, Hole 735B.

\begin{tabular}{|c|c|c|c|c|c|c|c|c|c|c|}
\hline $\begin{array}{l}\text { Lithologic } \\
\text { unit }\end{array}$ & $\begin{array}{c}\text { Number of } \\
\text { analyses }\end{array}$ & Plagioclase & Clinopyroxene & Orthopyroxene & Olivine & Amphibole & Chlorite & Ilmenite & Magnetite & Other \\
\hline I & 4 & 61 & 5 & 0 & 2 & 31 & 1 & 0 & 0 & 1 \\
\hline III & 4 & 49 & 28 & 0 & 8 & 6 & 1 & 4 & 2 & 2 \\
\hline IV & 9 & 48 & 23 & 0 & 0 & 12 & 1 & 8 & 5 & 2 \\
\hline V & 9 & 55 & 31 & 1 & 5 & 7 & 1 & 0 & 0 & 0 \\
\hline VII & 2 & 68 & 23 & 0 & 3 & 7 & 0 & 0 & 0 & 0 \\
\hline IX & 4 & 53 & 33 & 0 & 0 & 14 & 0 & 0 & 0 & 0 \\
\hline$x$ & 9 & 60 & 34 & 0 & 2 & 4 & 0 & 0 & 0 & 0 \\
\hline $\mathrm{XI}$ & 14 & 59 & 33 & 0 & 2 & 5 & 0 & 0 & 0 & 0 \\
\hline XII & 10 & 61 & 34 & 0 & 2 & 3 & 0 & 0 & 0 & 0 \\
\hline
\end{tabular}

Note: All data by X-ray diffraction analysis as reported in Table T2, p. 62. 
J. HeRTOGEN ET AL.

Lithology, Mineralogy, ANd Geochemistry of The Lower OCean Crust

Table T4. Average compositions of minerals in the major rock types, Hole 735B.

\begin{tabular}{lrcrcrrrr}
\hline \multicolumn{1}{c}{ Rock type } & $N$ & $\begin{array}{c}\text { Olivine } \\
(\mathrm{Fo})\end{array}$ & $N$ & $\begin{array}{c}\text { Orthopyroxene } \\
(\text { En) }\end{array}$ & $N$ & $\begin{array}{c}\text { Clinopyroxene } \\
\text { (En) }\end{array}$ & N & $\begin{array}{c}\text { Plagioclase } \\
\text { (An) }\end{array}$ \\
\hline Troctolite & $(10)$ & $\mathbf{8 0 . 6} \pm 1.3$ & & NA & $(13)$ & $\mathbf{4 6 . 9} \pm 2.0$ & $(10)$ & $\mathbf{6 5 . 0} \pm 1.7$ \\
Troctolitic gabbro and microgabbro & $(4)$ & $\mathbf{8 3 . 2} \pm 1.0$ & $(1)$ & $\mathbf{8 2 . 9}$ & $(3)$ & $\mathbf{5 0 . 7} \pm 3.5$ & $(5)$ & $\mathbf{7 4 . 3} \pm 3.1$ \\
Olivine gabbro and microgabbro & $(158)$ & $\mathbf{8 1 . 8} \pm 4.6$ & $(140)$ & $\mathbf{6 6 . 9} \pm 6.4$ & $(376)$ & $\mathbf{4 6 . 4} \pm 4.5$ & $(605)$ & $\mathbf{5 1 . 3} \pm 12.2$ \\
Gabbro & $(5)$ & $\mathbf{7 1 . 6} \pm 1.2$ & $(8)$ & $\mathbf{6 9 . 6} \pm 4.7$ & $(7)$ & $\mathbf{4 6 . 8} \pm 5.9$ & $(18)$ & $\mathbf{5 1 . 3} \pm 4.4$ \\
Gabbronorite & & NA & $(16)$ & $\mathbf{6 1 . 2} \pm 4.0$ & $(8)$ & $\mathbf{3 8 . 6} \pm 1.1$ & $(17)$ & $\mathbf{3 8 . 8} \pm 6.1$ \\
Fe-Ti oxide gabbro and microgabbro & $(47)$ & $\mathbf{5 4 . 4} \pm 11.7$ & $(85)$ & $\mathbf{6 0 . 7} \pm 6.6$ & $(164)$ & $\mathbf{4 1 . 5} \pm 4.6$ & $(303)$ & $\mathbf{3 7 . 8} \pm 11.8$ \\
Oxide gabbronorite & $(1)$ & $\mathbf{6 4 . 7}$ & $(6)$ & $\mathbf{6 1 . 9} \pm 2.1$ & $(18)$ & $\mathbf{4 0 . 0} \pm 2.0$ & $(16)$ & $\mathbf{4 4 . 2} \pm 2.4$ \\
\hline
\end{tabular}

Notes: Number in parentheses $=$ the number of microprobe analyses for that mineral. Bold number $=$ the average composition of the mineral for that rock type. \pm values $=1$ standard deviation. $N A=$ not analyzed. 
Table T5. Representative olivine compositions for the major rock types, Hole 735B. (Continued on next two pages.)

\begin{tabular}{|c|c|c|c|c|c|c|c|c|c|c|c|c|c|c|}
\hline \multirow{2}{*}{$\begin{array}{l}\text { Leg, hole: } \\
\text { Core, section: } \\
\text { Interval }(\mathrm{cm}) \text { : }\end{array}$} & \multicolumn{3}{|c|}{ 118-735B- } & \multirow{2}{*}{$\begin{array}{c}176-735 \mathrm{~B}- \\
91 \mathrm{R}-1 \\
73-76\end{array}$} & \multicolumn{6}{|c|}{ 118-735B- } & \multicolumn{4}{|c|}{ 176-735B- } \\
\hline & $\begin{array}{l}83 R-6 \\
53-59\end{array}$ & $\begin{array}{c}85 \mathrm{R}-7 \\
0-5\end{array}$ & $\begin{array}{c}87 \mathrm{R}-7 \\
0-7\end{array}$ & & $\begin{array}{c}\text { 79R-6 } \\
105-111\end{array}$ & $\begin{array}{l}45 \mathrm{R}-2 \\
19-24\end{array}$ & $\begin{array}{l}82 \mathrm{R}-4 \\
12-20\end{array}$ & $\begin{array}{l}75 R-5 \\
27-30\end{array}$ & $\begin{array}{c}71 \mathrm{R}-2 \\
115-125\end{array}$ & $\begin{array}{c}81 \mathrm{R}-1 \\
130-132\end{array}$ & $\begin{array}{c}188 \mathrm{R}-5 \\
13-18\end{array}$ & $\begin{array}{c}168 \mathrm{R}-2 \\
140-146\end{array}$ & $\begin{array}{c}145 \mathrm{R}-1 \\
31-41\end{array}$ & $\begin{array}{c}149 R-1 \\
56-65\end{array}$ \\
\hline Rock type: & \multicolumn{2}{|c|}{ Troctolite } & \multicolumn{3}{|c|}{ Troctolitic gabbro } & \multicolumn{9}{|c|}{ Olivine Gabbro } \\
\hline \multicolumn{15}{|c|}{ Major element oxide (wt\%): } \\
\hline $\mathrm{SiO}_{2}$ & 39.51 & 39.17 & 39.02 & 38.73 & 37.69 & 38.42 & 38.44 & 37.27 & 38.27 & 38.46 & 37.92 & 37.14 & 37.21 & 37.17 \\
\hline $\mathrm{TiO}_{2}$ & 0.00 & 0.00 & 0.07 & 0.07 & 0.00 & 0.00 & 0.00 & 0.00 & 0.00 & 0.00 & 0.06 & 0.00 & 0.09 & 0.00 \\
\hline $\mathrm{Al}_{2} \mathrm{O}_{3}$ & 0.00 & 0.00 & 0.01 & 0.00 & 0.00 & 0.00 & 0.00 & 0.00 & 0.02 & 0.00 & 0.00 & 0.00 & 0.03 & 0.01 \\
\hline $\mathrm{FeO}$ & 15.56 & 17.40 & 18.96 & 16.12 & 17.82 & 17.42 & 18.42 & 20.38 & 21.95 & 22.78 & 24.08 & 25.97 & 28.07 & 30.26 \\
\hline $\mathrm{NiO}$ & 0.03 & 0.06 & 0.10 & 0.04 & 0.05 & 0.09 & 0.03 & 0.00 & 0.12 & 0.03 & 0.00 & 0.00 & 0.08 & 0.00 \\
\hline $\mathrm{MnO}$ & 0.31 & 0.30 & 0.28 & 0.36 & 0.38 & 0.43 & 0.38 & 0.49 & 0.33 & 0.50 & 0.28 & 0.50 & 0.52 & 0.53 \\
\hline $\mathrm{MgO}$ & 44.68 & 43.17 & 41.87 & 44.76 & 42.26 & 44.00 & 43.08 & 40.97 & 39.20 & 38.83 & 38.26 & 35.47 & 35.02 & 31.67 \\
\hline $\mathrm{CaO}$ & 0.05 & 0.06 & 0.04 & 0.00 & 0.03 & 0.00 & 0.06 & 0.00 & 0.05 & 0.07 & 0.06 & 0.05 & 0.14 & 0.00 \\
\hline Total & 100.14 & 100.16 & 100.36 & 100.07 & 98.23 & 100.36 & 100.41 & 99.11 & 99.94 & 100.67 & 100.66 & 99.13 & 101.16 & 99.64 \\
\hline \multicolumn{15}{|c|}{ Number of cations based on $4 \mathrm{O}$ : } \\
\hline $\mathrm{Si}$ & 0.9941 & 0.9941 & 0.9954 & 0.9798 & 0.9810 & 0.9761 & 0.9799 & 0.9739 & 0.9953 & 0.9965 & 0.9888 & 0.9947 & 0.9860 & 1.0092 \\
\hline $\mathrm{Ti}$ & 0.0000 & 0.0000 & 0.0013 & 0.0014 & 0.0000 & 0.0000 & 0.0000 & 0.0000 & 0.0000 & 0.0000 & 0.0012 & 0.0000 & 0.0017 & 0.0000 \\
\hline $\mathrm{Al}$ & 0.0000 & 0.0000 & 0.0004 & 0.0000 & 0.0000 & 0.0000 & 0.0000 & 0.0000 & 0.0006 & 0.0000 & 0.0000 & 0.0000 & 0.0009 & 0.0003 \\
\hline $\mathrm{Fe}^{+2}$ & 0.3274 & 0.3692 & 0.4043 & 0.3409 & 0.3878 & 0.3701 & 0.3926 & 0.4453 & 0.4774 & 0.4935 & 0.5250 & 0.5815 & 0.6221 & 0.6870 \\
\hline $\mathrm{Ni}$ & 0.0006 & 0.0012 & 0.0021 & 0.0008 & 0.0010 & 0.0018 & 0.0006 & 0.0000 & 0.0025 & 0.0006 & 0.0000 & 0.0000 & 0.0018 & 0.0000 \\
\hline $\mathrm{Mn}$ & 0.0066 & 0.0064 & 0.0060 & 0.0077 & 0.0084 & 0.0093 & 0.0082 & 0.0108 & 0.0073 & 0.0110 & 0.0061 & 0.0113 & 0.0117 & 0.0122 \\
\hline $\mathrm{Mg}$ & 1.6759 & 1.6333 & 1.5922 & 1.6881 & 1.6399 & 1.6666 & 1.6372 & 1.5960 & 1.5199 & 1.4999 & 1.4872 & 1.4163 & 1.3837 & 1.2821 \\
\hline $\mathrm{Ca}$ & 0.0013 & 0.0016 & 0.0012 & 0.0000 & 0.0008 & 0.0000 & 0.0016 & 0.0000 & 0.0014 & 0.0019 & 0.0017 & 0.0014 & 0.0039 & 0.0000 \\
\hline Total & 3.0059 & 3.0059 & 3.0026 & 3.0188 & 3.0190 & 3.0239 & 3.0201 & 3.0261 & 3.0038 & 3.0035 & 3.0100 & 3.0053 & 3.0109 & 2.9904 \\
\hline Fo & 83.7 & 81.6 & 79.7 & 83.2 & 80.9 & 81.8 & 80.7 & 78.2 & 76.1 & 75.2 & 73.9 & 70.9 & 69.0 & 65.1 \\
\hline $\mathrm{Fa}$ & 16.3 & 18.4 & 20.3 & 16.8 & 19.1 & 18.2 & 19.3 & 21.8 & 23.9 & 24.8 & 26.1 & 29.1 & 31.0 & 34.9 \\
\hline
\end{tabular}


Table T5 (continued).

\begin{tabular}{|c|c|c|c|c|c|c|c|c|c|c|c|c|}
\hline \multirow{2}{*}{$\begin{array}{l}\text { Leg, hole: } \\
\text { Core, section: } \\
\text { Interval }(\mathrm{cm}) \text { : }\end{array}$} & \multicolumn{4}{|c|}{ 176-735B- } & \multirow{2}{*}{$\begin{array}{c}118-735 \mathrm{~B}- \\
54 \mathrm{R}-4 \\
0-9\end{array}$} & \multicolumn{4}{|c|}{ 176-735B- } & \multicolumn{2}{|c|}{$118-735 \mathrm{~B}-$} & \multirow{2}{*}{$\begin{array}{c}176-735 \mathrm{~B}- \\
118 \mathrm{R}-4 \\
50-55\end{array}$} \\
\hline & $\begin{array}{l}145 R-5 \\
49-53\end{array}$ & $\begin{array}{c}190 \mathrm{R}-6 \\
42-48\end{array}$ & $\begin{array}{l}149 \mathrm{R}-4 \\
82-87\end{array}$ & $\begin{array}{l}149 \mathrm{R}-4 \\
82-87\end{array}$ & & $\begin{array}{c}162 \mathrm{R}-6 \\
29-36\end{array}$ & $\begin{array}{c}119 R-5 \\
62-68\end{array}$ & $\begin{array}{c}157 \mathrm{R}-7 \\
1-5\end{array}$ & $\begin{array}{c}118 \mathrm{R}-1 \\
135-140\end{array}$ & $\begin{array}{l}41 \mathrm{R}-4 \\
68-70\end{array}$ & $\begin{array}{l}20 \mathrm{R}-2 \\
13-21\end{array}$ & \\
\hline Rock type: & \multicolumn{3}{|c|}{ Gabbro } & \multicolumn{9}{|c|}{ Oxide gabbro } \\
\hline \multicolumn{13}{|c|}{ Major element oxide (wt\%): } \\
\hline $\mathrm{SiO}_{2}$ & 36.38 & 37.31 & 37.08 & 36.96 & 36.98 & 37.69 & 37.29 & 36.43 & 36.82 & 36.35 & 35.28 & 35.42 \\
\hline $\mathrm{TiO}_{2}$ & 0.00 & 0.00 & 0.02 & 0.00 & 0.00 & 0.01 & 0.00 & 0.00 & 0.04 & 0.00 & 0.02 & 0.00 \\
\hline $\mathrm{Al}_{2} \mathrm{O}_{3}$ & 0.00 & 0.00 & 0.04 & 0.00 & 0.00 & 0.00 & 0.00 & 0.00 & 0.00 & 0.00 & 0.12 & 0.00 \\
\hline $\mathrm{FeO}$ & 32.88 & 25.89 & 27.02 & 28.39 & 26.34 & 26.83 & 27.76 & 30.24 & 31.64 & 35.08 & 35.78 & 37.32 \\
\hline $\mathrm{NiO}$ & 0.00 & 0.08 & 0.00 & 0.10 & 0.00 & 0.00 & 0.09 & 0.12 & 0.06 & 0.03 & 0.03 & 0.00 \\
\hline $\mathrm{MnO}$ & 0.63 & 0.38 & 0.51 & 0.47 & 0.59 & 0.33 & 0.30 & 0.51 & 0.46 & 0.55 & 0.53 & 0.71 \\
\hline $\mathrm{MgO}$ & 30.35 & 36.69 & 35.62 & 34.83 & 36.18 & 35.35 & 34.35 & 32.18 & 31.35 & 29.40 & 27.46 & 26.11 \\
\hline $\mathrm{CaO}$ & 0.10 & 0.07 & 0.05 & 0.02 & 0.00 & 0.11 & 0.33 & 0.00 & 0.06 & 0.06 & 0.04 & 0.00 \\
\hline Total & 100.35 & 100.42 & 100.32 & 100.77 & 100.09 & 100.32 & 100.12 & 99.48 & 100.45 & 101.47 & 99.26 & 99.56 \\
\hline \multicolumn{13}{|c|}{ Number of cations based on $4 \mathrm{O}$ : } \\
\hline $\mathrm{Si}$ & 0.9956 & 0.9856 & 0.9859 & 0.9850 & 0.9834 & 0.9989 & 0.9966 & 0.9936 & 0.9991 & 0.9930 & 0.9926 & 1.0008 \\
\hline $\mathrm{Ti}$ & 0.0000 & 0.0000 & 0.0004 & 0.0000 & 0.0000 & 0.0002 & 0.0000 & 0.0000 & 0.0009 & 0.0000 & 0.0004 & 0.0000 \\
\hline $\mathrm{Al}$ & 0.0000 & 0.0000 & 0.0011 & 0.0000 & 0.0000 & 0.0000 & 0.0000 & 0.0000 & 0.0000 & 0.0000 & 0.0040 & 0.0000 \\
\hline $\mathrm{Fe}^{+2}$ & 0.7526 & 0.5719 & 0.6008 & 0.6328 & 0.5857 & 0.5946 & 0.6203 & 0.6898 & 0.7180 & 0.8014 & 0.8417 & 0.8818 \\
\hline $\mathrm{Ni}$ & 0.0000 & 0.0017 & 0.0000 & 0.0022 & 0.0000 & 0.0000 & 0.0018 & 0.0027 & 0.0014 & 0.0007 & 0.0007 & 0.0000 \\
\hline $\mathrm{Mn}$ & 0.0147 & 0.0084 & 0.0114 & 0.0107 & 0.0133 & 0.0073 & 0.0068 & 0.0118 & 0.0106 & 0.0127 & 0.0126 & 0.0169 \\
\hline $\mathrm{Mg}$ & 1.2384 & 1.4447 & 1.4121 & 1.3839 & 1.4343 & 1.3967 & 1.3685 & 1.3086 & 1.2681 & 1.1974 & 1.1518 & 1.0998 \\
\hline $\mathrm{Ca}$ & 0.0031 & 0.0020 & 0.0014 & 0.0005 & 0.0000 & 0.0032 & 0.0093 & 0.0000 & 0.0017 & 0.0018 & 0.0012 & 0.0000 \\
\hline Total & 3.0044 & 3.0144 & 3.0120 & 3.0150 & 3.0166 & 3.0009 & 3.0034 & 3.0064 & 2.9999 & 3.0070 & 3.0010 & 2.9992 \\
\hline Fo & 62.2 & 71.6 & 70.2 & 68.6 & 71.0 & 70.1 & 68.8 & 65.5 & 63.8 & 59.9 & 57.8 & 55.5 \\
\hline $\mathrm{Fa}$ & 37.8 & 28.4 & 29.8 & 31.4 & 29.0 & 29.9 & 31.2 & 34.5 & 36.2 & 40.1 & 42.2 & 44.5 \\
\hline
\end{tabular}


Table T5 (continued).

\begin{tabular}{|c|c|c|c|c|c|c|c|c|}
\hline \multirow{2}{*}{$\begin{array}{l}\text { Leg, hole: } \\
\text { Core, section: } \\
\text { Interval }(\mathrm{cm}) \text { : }\end{array}$} & \multicolumn{8}{|c|}{$118-735 \mathrm{~B}-$} \\
\hline & $\begin{array}{l}45 R-1 \\
37-44\end{array}$ & $\begin{array}{c}51 R-3 \\
110-114\end{array}$ & $\begin{array}{c}\text { 51R-3 } \\
110-114\end{array}$ & $\begin{array}{l}80 R-7 \\
56-65\end{array}$ & $\begin{array}{c}55 \mathrm{R}-2 \\
110-120\end{array}$ & $\begin{array}{c}54 \mathrm{R}-4 \\
0-9\end{array}$ & $\begin{array}{c}54 R-4 \\
0-9\end{array}$ & $\begin{array}{c}74 \mathrm{R}-6 \\
0-8\end{array}$ \\
\hline Rock type: & \multicolumn{7}{|c|}{ Oxide gabbro } & Oxide gabbronorite \\
\hline \multicolumn{9}{|c|}{ Major element oxide (wt\%): } \\
\hline $\mathrm{SiO}_{2}$ & 34.10 & 33.85 & 33.70 & 34.21 & 33.69 & 32.80 & 32.65 & 36.86 \\
\hline $\mathrm{TiO}_{2}$ & 0.00 & 0.00 & 0.00 & 0.00 & 0.00 & 0.00 & 0.00 & 0.00 \\
\hline $\mathrm{Al}_{2} \mathrm{O}_{3}$ & 0.04 & 0.00 & 0.00 & 0.00 & 0.00 & 0.00 & 0.00 & 0.00 \\
\hline $\mathrm{FeO}$ & 40.28 & 44.49 & 46.58 & 47.95 & 50.28 & 51.47 & 52.35 & 31.27 \\
\hline $\mathrm{NiO}$ & 0.00 & 0.00 & 0.00 & 0.04 & 0.07 & 0.00 & 0.04 & 0.00 \\
\hline $\mathrm{MnO}$ & 0.63 & 0.71 & 0.74 & 0.73 & 1.00 & 1.02 & 1.47 & 0.63 \\
\hline $\mathrm{MgO}$ & 23.64 & 21.38 & 19.30 & 18.25 & 16.09 & 14.41 & 13.17 & 32.11 \\
\hline $\mathrm{CaO}$ & 0.05 & 0.00 & 0.00 & 0.07 & 0.09 & 0.10 & 0.08 & 0.07 \\
\hline Total & 98.74 & 100.43 & 100.32 & 101.25 & 101.22 & 99.80 & 99.76 & 100.94 \\
\hline \multicolumn{9}{|c|}{ Number of cations based on $4 \mathrm{O}$ : } \\
\hline $\mathrm{Si}$ & 0.9899 & 0.9856 & 0.9930 & 1.0029 & 1.0026 & 1.0008 & 1.0041 & 0.9939 \\
\hline $\mathrm{Ti}$ & 0.0000 & 0.0000 & 0.0000 & 0.0000 & 0.0000 & 0.0000 & 0.0000 & 0.0000 \\
\hline $\mathrm{Al}$ & 0.0015 & 0.0000 & 0.0000 & 0.0000 & 0.0000 & 0.0000 & 0.0000 & 0.0000 \\
\hline $\mathrm{Fe}^{+2}$ & 0.9778 & 1.0832 & 1.1477 & 1.1754 & 1.2512 & 1.3132 & 1.3462 & 0.7050 \\
\hline $\mathrm{Ni}$ & 0.0000 & 0.0000 & 0.0000 & 0.0009 & 0.0017 & 0.0000 & 0.0010 & 0.0000 \\
\hline $\mathrm{Mn}$ & 0.0154 & 0.0175 & 0.0185 & 0.0181 & 0.0252 & 0.0264 & 0.0383 & 0.0144 \\
\hline $\mathrm{Mg}$ & 1.0230 & 0.9281 & 0.8478 & 0.7976 & 0.7139 & 0.6555 & 0.6038 & 1.2908 \\
\hline $\mathrm{Ca}$ & 0.0016 & 0.0000 & 0.0000 & 0.0022 & 0.0029 & 0.0033 & 0.0026 & 0.0020 \\
\hline Total & 3.0078 & 3.0144 & 3.0070 & 2.9971 & 2.9974 & 2.9992 & 2.9959 & 3.0061 \\
\hline Fo & 51.1 & 46.1 & 42.5 & 40.4 & 36.3 & 33.3 & 31.0 & 64.7 \\
\hline $\mathrm{Fa}$ & 48.9 & 53.9 & 57.5 & 59.6 & 63.7 & 66.7 & 69.0 & 35.3 \\
\hline
\end{tabular}


Table T6. Representative orthopyroxene compositions for the major rock types, Hole 735B. (Continued on next page.)

\begin{tabular}{|c|c|c|c|c|c|c|c|c|c|c|c|c|c|c|c|c|}
\hline \multirow{2}{*}{$\begin{array}{l}\text { Leg, hole: } \\
\text { Core, section: } \\
\text { Interval }(\mathrm{cm}):\end{array}$} & \multicolumn{2}{|c|}{ 118-735B- } & \multicolumn{14}{|c|}{ 176-735B- } \\
\hline & $\begin{array}{c}85 R-7 \\
0-5\end{array}$ & $\begin{array}{l}69 \mathrm{R}-5 \\
31-41\end{array}$ & $\begin{array}{c}207 R-5 \\
76-81\end{array}$ & $\begin{array}{c}189 \mathrm{R}-7 \\
75-81\end{array}$ & $\begin{array}{c}158 \mathrm{R}-1 \\
69-75\end{array}$ & $\begin{array}{c}161 \mathrm{R}-2 \\
114-119\end{array}$ & $\begin{array}{c}161 R-3 \\
128-135\end{array}$ & $\begin{array}{c}145 R-5 \\
49-53\end{array}$ & $\begin{array}{c}161 R-3 \\
128-135\end{array}$ & $\begin{array}{c}161 \mathrm{R}-2 \\
114-119\end{array}$ & $\begin{array}{c}190 \mathrm{R}-6 \\
42-48\end{array}$ & $\begin{array}{c}147 R-5 \\
67-75\end{array}$ & $\begin{array}{c}162 \mathrm{R}-6 \\
29-36\end{array}$ & $\begin{array}{c}154 \mathrm{R}-3 \\
71-79\end{array}$ & $\begin{array}{c}154 R-3 \\
71-79\end{array}$ & $\begin{array}{c}154 R-3 \\
71-79\end{array}$ \\
\hline Rock type: & $\begin{array}{c}\text { Troctolitic } \\
\text { gabbro }\end{array}$ & \multicolumn{9}{|c|}{ Olivine Gabbro } & \multicolumn{2}{|c|}{ Gabbro } & \multicolumn{4}{|c|}{ Oxide gabbro } \\
\hline \multicolumn{17}{|c|}{ Major element oxide (wt\%): } \\
\hline $\mathrm{SiO}_{2}$ & 55.37 & 54.41 & 53.36 & 53.56 & 53.18 & 52.25 & 52.51 & 52.45 & 51.77 & 50.80 & 53.67 & 52.89 & 53.49 & 53.24 & 52.90 & 52.05 \\
\hline $\mathrm{TiO}_{2}$ & 0.35 & 0.26 & 0.45 & 0.38 & 0.39 & 0.26 & 0.35 & 0.36 & 0.21 & 0.08 & 0.26 & 0.27 & 0.41 & 0.06 & 0.32 & 0.35 \\
\hline $\mathrm{Al}_{2} \mathrm{O}_{3}$ & 1.16 & 1.35 & 1.41 & 1.14 & 1.29 & 1.07 & 1.04 & 0.98 & 0.66 & 0.31 & 1.27 & 0.81 & 1.13 & 0.92 & 1.14 & 0.97 \\
\hline $\mathrm{FeO}$ & 10.47 & 12.92 & 15.53 & 16.92 & 17.67 & 18.71 & 20.25 & 22.98 & 24.25 & 27.67 & 15.65 & 20.43 & 16.74 & 18.32 & 19.36 & 21.80 \\
\hline $\mathrm{Cr}_{2} \mathrm{O}_{3}$ & 0.06 & 0.00 & 0.00 & 0.03 & 0.06 & 0.11 & 0.09 & 0.00 & 0.07 & 0.00 & 0.10 & 0.00 & 0.04 & 0.03 & 0.03 & 0.08 \\
\hline $\mathrm{MnO}$ & 0.30 & 0.31 & 0.35 & 0.36 & 0.38 & 0.34 & 0.54 & 0.62 & 0.79 & 1.26 & 0.30 & 0.57 & 0.44 & 0.57 & 0.60 & 0.65 \\
\hline $\mathrm{MgO}$ & 31.14 & 28.85 & 27.89 & 26.31 & 25.61 & 24.91 & 23.26 & 22.47 & 20.85 & 18.18 & 27.71 & 23.21 & 26.59 & 25.83 & 24.63 & 22.90 \\
\hline $\mathrm{CaO}$ & 0.76 & 0.86 & 1.29 & 1.05 & 1.49 & 1.50 & 1.51 & 1.07 & 1.41 & 1.11 & 1.23 & 0.85 & 1.15 & 0.77 & 1.00 & 0.92 \\
\hline $\mathrm{Na}_{2} \mathrm{O}$ & 0.00 & 0.04 & 0.20 & 0.17 & 0.28 & 0.12 & 0.16 & 0.26 & 0.11 & 0.22 & 0.24 & 0.12 & 0.18 & 0.16 & 0.19 & 0.11 \\
\hline Total & 99.61 & 99.00 & 100.48 & 99.91 & 100.36 & 99.28 & 99.72 & 101.21 & 100.13 & 99.63 & 100.43 & 99.15 & 100.16 & 99.89 & 100.17 & 99.84 \\
\hline \multicolumn{17}{|c|}{ Number of cations based on $6 \mathrm{O}$ : } \\
\hline $\mathrm{Si}$ & 1.9584 & 1.9590 & 1.9248 & 1.9512 & 1.9402 & 1.9387 & 1.9527 & 1.9447 & 1.9565 & 1.9667 & 1.9363 & 1.9733 & 1.9445 & 1.9536 & 1.9472 & 1.9463 \\
\hline $\mathrm{Ti}$ & 0.0093 & 0.0070 & 0.0123 & 0.0104 & 0.0108 & 0.0073 & 0.0099 & 0.0100 & 0.0061 & 0.0024 & 0.0070 & 0.0076 & 0.0111 & 0.0017 & 0.0089 & 0.0099 \\
\hline $\mathrm{Al}^{\mathrm{IV}}$ & 0.0416 & 0.0410 & 0.0600 & 0.0488 & 0.0554 & 0.0466 & 0.0457 & 0.0429 & 0.0292 & 0.0141 & 0.0540 & 0.0267 & 0.0485 & 0.0398 & 0.0495 & 0.0429 \\
\hline $\mathrm{Al}^{\mathrm{VI}}$ & 0.0068 & 0.0163 & 0.0000 & 0.0000 & 0.0000 & 0.0000 & 0.0000 & 0.0000 & 0.0000 & 0.0000 & 0.0000 & 0.0090 & 0.0000 & 0.0000 & 0.0000 & 0.0000 \\
\hline $\mathrm{Fe}^{+2}$ & 0.3097 & 0.3888 & 0.4683 & 0.5154 & 0.5390 & 0.5805 & 0.6296 & 0.7125 & 0.7663 & 0.8956 & 0.4721 & 0.6375 & 0.5089 & 0.5620 & 0.5958 & 0.6815 \\
\hline $\mathrm{Cr}$ & 0.0017 & 0.0000 & 0.0000 & 0.0008 & 0.0018 & 0.0033 & 0.0027 & 0.0000 & 0.0022 & 0.0000 & 0.0028 & 0.0000 & 0.0012 & 0.0008 & 0.0010 & 0.0022 \\
\hline $\mathrm{Mn}$ & 0.0090 & 0.0095 & 0.0108 & 0.0112 & 0.0117 & 0.0108 & 0.0171 & 0.0194 & 0.0252 & 0.0413 & 0.0092 & 0.0179 & 0.0134 & 0.0177 & 0.0187 & 0.0207 \\
\hline $\mathrm{Mg}$ & 1.6420 & 1.5491 & 1.4999 & 1.4290 & 1.3930 & 1.3779 & 1.2894 & 1.2422 & 1.1749 & 1.0495 & 1.4907 & 1.2912 & 1.4410 & 1.4128 & 1.3515 & 1.2767 \\
\hline $\mathrm{Ca}$ & 0.0288 & 0.0332 & 0.0497 & 0.0409 & 0.0584 & 0.0596 & 0.0602 & 0.0425 & 0.0572 & 0.0459 & 0.0476 & 0.0338 & 0.0447 & 0.0303 & 0.0393 & 0.0370 \\
\hline $\mathrm{Na}$ & 0.0000 & 0.0080 & 0.0393 & 0.0343 & 0.0562 & 0.0249 & 0.0332 & 0.0541 & 0.0235 & 0.0476 & 0.0479 & 0.0247 & 0.0353 & 0.0325 & 0.0385 & 0.0228 \\
\hline Total & 4.0072 & 4.0120 & 4.0651 & 4.0419 & 4.0667 & 4.0496 & 4.0406 & 4.0684 & 4.0411 & 4.0632 & 4.0677 & 4.0217 & 4.0486 & 4.0513 & 4.0504 & 4.0400 \\
\hline En & 82.9 & 78.6 & 74.3 & 72.0 & 70.0 & 68.3 & 65.2 & 62.2 & 58.8 & 52.7 & 74.2 & 65.8 & 72.2 & 70.5 & 68.0 & 64.0 \\
\hline $\mathrm{Fe}$ & 15.6 & 19.7 & 23.2 & 26.0 & 27.1 & 28.8 & 31.8 & 35.7 & 38.3 & 45.0 & 23.5 & 32.5 & 25.5 & 28.0 & 30.0 & 34.2 \\
\hline Wo & 1.5 & 1.7 & 2.5 & 2.1 & 2.9 & 3.0 & 3.0 & 2.1 & 2.9 & 2.3 & 2.4 & 1.7 & 2.2 & 1.5 & 2.0 & 1.9 \\
\hline
\end{tabular}

Note: $\mathrm{En}=$ enstatite, $\mathrm{Fe}=$ ferrosilite, $\mathrm{Wo}=$ wollastonite. 
Table T6 (continued).

\begin{tabular}{|c|c|c|c|c|c|c|c|c|c|c|c|c|c|c|c|}
\hline \multirow{2}{*}{$\begin{array}{l}\text { Leg, hole: } \\
\text { Core, section: } \\
\text { Interval }(\mathrm{cm}) \text { : }\end{array}$} & \multicolumn{4}{|c|}{$118-735 \mathrm{~B}-$} & \multirow{2}{*}{$\begin{array}{c}176-735 \mathrm{~B}- \\
100 \mathrm{R}-1 \\
22-27\end{array}$} & \multicolumn{3}{|c|}{ 118-735B- } & \multicolumn{3}{|c|}{ 176-735B- } & \multicolumn{4}{|c|}{ 118-735B- } \\
\hline & $\begin{array}{c}44 \mathrm{R}-2 \\
6-8\end{array}$ & $\begin{array}{c}47 R-2 \\
92-100\end{array}$ & $\begin{array}{l}48 \mathrm{R}-4 \\
32-37\end{array}$ & $\begin{array}{l}47 \mathrm{R}-1 \\
70-78\end{array}$ & & $\begin{array}{l}77 R-4 \\
70-72\end{array}$ & $\begin{array}{l}53 R-4 \\
68-78\end{array}$ & $\begin{array}{l}53 R-4 \\
68-78\end{array}$ & $\begin{array}{c}\text { 157R-1 } \\
104-111\end{array}$ & $\begin{array}{c}\text { 157R-1 } \\
104-111\end{array}$ & $\begin{array}{c}\text { 157R-1 } \\
104-111\end{array}$ & $\begin{array}{l}19 R-5 \\
62-73\end{array}$ & $\begin{array}{l}19 R-5 \\
62-73\end{array}$ & $\begin{array}{c}2 \mathrm{D}-1 \\
123-127\end{array}$ & $\begin{array}{c}74 \mathrm{R}-6 \\
0-8\end{array}$ \\
\hline Rock type: & \multicolumn{8}{|c|}{ Oxide gabbro } & \multicolumn{3}{|c|}{ Olivine gabbronorite } & \multicolumn{2}{|c|}{ Gabbronorite } & \multicolumn{2}{|c|}{ Oxide gabbronorite } \\
\hline \multicolumn{16}{|c|}{ Major element oxide (wt\%): } \\
\hline $\mathrm{SiO}_{2}$ & 51.94 & 51.32 & 51.78 & 50.22 & 51.31 & 52.42 & 50.36 & 50.45 & 53.09 & 52.31 & 52.26 & 55.45 & 51.69 & 52.47 & 50.87 \\
\hline $\mathrm{TiO}_{2}$ & 0.29 & 0.29 & 0.22 & 0.21 & 0.29 & 0.24 & 0.09 & 0.09 & 0.18 & 0.30 & 0.40 & 0.58 & 0.19 & 0.36 & 0.41 \\
\hline $\mathrm{Al}_{2} \mathrm{O}_{3}$ & 0.92 & 0.72 & 0.70 & 0.67 & 0.53 & 0.61 & 0.15 & 0.34 & 0.99 & 0.80 & 0.95 & 0.98 & 1.29 & 1.13 & 0.77 \\
\hline $\mathrm{FeO}$ & 22.75 & 22.69 & 24.28 & 25.54 & 26.74 & 28.38 & 32.46 & 33.96 & 19.30 & 21.54 & 22.02 & 18.99 & 21.97 & 21.00 & 22.60 \\
\hline $\mathrm{Cr}_{2} \mathrm{O}_{3}$ & 0.00 & 0.00 & 0.00 & 0.00 & 0.10 & 0.02 & 0.00 & 0.04 & 0.00 & 0.00 & 0.04 & 0.03 & 0.03 & 0.03 & 0.00 \\
\hline $\mathrm{MnO}$ & 0.75 & 0.65 & 0.98 & 0.74 & 0.61 & 0.82 & 1.05 & 0.94 & 0.64 & 0.56 & 0.62 & 0.64 & 0.51 & 0.51 & 0.82 \\
\hline $\mathrm{MgO}$ & 22.68 & 20.46 & 19.61 & 18.18 & 18.13 & 17.32 & 14.78 & 13.71 & 23.80 & 22.61 & 22.35 & 21.33 & 21.10 & 22.14 & 22.01 \\
\hline $\mathrm{CaO}$ & 1.20 & 1.36 & 2.42 & 1.19 & 2.33 & 2.68 & 1.24 & 1.13 & 1.04 & 1.76 & 1.75 & 0.80 & 1.64 & 1.33 & 3.84 \\
\hline $\mathrm{Na}_{2} \mathrm{O}$ & 0.00 & 0.02 & 0.03 & 0.00 & 0.10 & 0.00 & 0.00 & 0.00 & 0.17 & 0.06 & 0.19 & 0.25 & 0.01 & 0.11 & 0.04 \\
\hline Total & 100.53 & 98.74 & 100.02 & 98.07 & 100.13 & 102.49 & 100.13 & 100.66 & 99.21 & 99.95 & 100.58 & 99.05 & 98.43 & 99.09 & 101.36 \\
\hline \multicolumn{16}{|c|}{ Number of cations based on $6 \mathrm{O}$ : } \\
\hline $\mathrm{Si}$ & 1.9393 & 1.9760 & 1.9649 & 1.9781 & 1.9658 & 1.9729 & 1.9812 & 1.9846 & 1.9706 & 1.9538 & 1.9456 & 2.0429 & 1.9628 & 1.9670 & 1.9043 \\
\hline $\mathrm{Ti}$ & 0.0081 & 0.0084 & 0.0063 & 0.0063 & 0.0083 & 0.0068 & 0.0027 & 0.0027 & 0.0051 & 0.0085 & 0.0112 & 0.0161 & 0.0054 & 0.0103 & 0.0115 \\
\hline $\mathrm{Al}^{\mathrm{IV}}$ & 0.0405 & 0.0240 & 0.0313 & 0.0219 & 0.0238 & 0.0271 & 0.0070 & 0.0154 & 0.0294 & 0.0353 & 0.0419 & -0.0429 & 0.0372 & 0.0330 & 0.0340 \\
\hline $\mathrm{Al}^{\mathrm{V}} \mathrm{V}^{\mathrm{I}}$ & 0.0000 & 0.0084 & 0.0000 & 0.0094 & 0.0000 & 0.0000 & 0.0000 & 0.0003 & 0.0138 & 0.0000 & 0.0000 & 0.0854 & 0.0205 & 0.0170 & 0.0000 \\
\hline $\mathrm{Fe}^{+2}$ & 0.7103 & 0.7305 & 0.7704 & 0.8412 & 0.8567 & 0.8931 & 1.0678 & 1.1171 & 0.5990 & 0.6728 & 0.6855 & 0.5850 & 0.6976 & 0.6582 & 0.7074 \\
\hline $\mathrm{Cr}$ & 0.0000 & 0.0000 & 0.0000 & 0.0000 & 0.0030 & 0.0006 & 0.0000 & 0.0012 & 0.0000 & 0.0000 & 0.0010 & 0.0009 & 0.0009 & 0.0009 & 0.0000 \\
\hline $\mathrm{Mn}$ & 0.0237 & 0.0211 & 0.0315 & 0.0248 & 0.0196 & 0.0261 & 0.0350 & 0.0313 & 0.0201 & 0.0178 & 0.0196 & 0.0200 & 0.0164 & 0.0160 & 0.0260 \\
\hline $\mathrm{Mg}$ & 1.2624 & 1.1743 & 1.1094 & 1.0678 & 1.0358 & 0.9718 & 0.8668 & 0.8040 & 1.3172 & 1.2592 & 1.2403 & 1.1715 & 1.1945 & 1.2373 & 1.2284 \\
\hline $\mathrm{Ca}$ & 0.0480 & 0.0560 & 0.0984 & 0.0504 & 0.0955 & 0.1081 & 0.0523 & 0.0476 & 0.0415 & 0.0703 & 0.0698 & 0.0316 & 0.0667 & 0.0536 & 0.1540 \\
\hline $\mathrm{Na}$ & 0.0000 & 0.0037 & 0.0064 & 0.0004 & 0.0224 & 0.0000 & 0.0000 & 0.0000 & 0.0347 & 0.0121 & 0.0400 & 0.0560 & 0.0021 & 0.0239 & 0.0079 \\
\hline Total & 4.0323 & 4.0025 & 4.0185 & 4.0003 & 4.0311 & 4.0065 & 4.0127 & 4.0043 & 4.0314 & 4.0300 & 4.0548 & 3.9664 & 4.0042 & 4.0167 & 4.0736 \\
\hline En & 62.5 & 59.9 & 56.1 & 54.5 & 52.1 & 49.3 & 43.6 & 40.8 & 67.3 & 62.9 & 62.2 & 65.5 & 61.0 & 63.5 & 58.8 \\
\hline $\mathrm{Fe}$ & 35.1 & 37.3 & 38.9 & 42.9 & 43.1 & 45.3 & 53.7 & 56.7 & 30.6 & 33.6 & 34.4 & 32.7 & 35.6 & 33.8 & 33.9 \\
\hline Wo & 2.4 & 2.9 & 5.0 & 2.6 & 4.8 & 5.5 & 2.6 & 2.4 & 2.1 & 3.5 & 3.5 & 1.8 & 3.4 & 2.7 & 7.4 \\
\hline
\end{tabular}


Table T7. Representative clinopyroxene compositions for the major rock types, Hole 735B. (Continued on next two pages.)

\begin{tabular}{|c|c|c|c|c|c|c|c|c|c|c|c|c|c|c|c|}
\hline \multirow{2}{*}{$\begin{array}{l}\text { Leg, hole: } \\
\text { Core, section: } \\
\text { Interval }(\mathrm{cm}) \text { : }\end{array}$} & \multicolumn{5}{|c|}{ 118-735B- } & \multirow{2}{*}{$\begin{array}{c}176-735 \mathrm{~B}- \\
91 \mathrm{R}-1 \\
73-76\end{array}$} & \multirow{2}{*}{$\begin{array}{c}118-735 B- \\
35 R-1 \\
45-47\end{array}$} & \multicolumn{8}{|c|}{ 176-735B- } \\
\hline & $\begin{array}{l}83 R-6 \\
53-59\end{array}$ & $\begin{array}{c}87 \mathrm{R}-7 \\
0-7\end{array}$ & $\begin{array}{c}87 R-7 \\
0-7\end{array}$ & $\begin{array}{l}87 R-7 \\
0-7\end{array}$ & $\begin{array}{c}\text { 79R-6 } \\
105-111\end{array}$ & & & $\begin{array}{c}206 \mathrm{R}-4 \\
139-144\end{array}$ & $\begin{array}{c}178 R-4 \\
74-77\end{array}$ & $\begin{array}{c}183 R-3 \\
69-78\end{array}$ & $\begin{array}{c}172 \mathrm{R}-7 \\
124-128\end{array}$ & $\begin{array}{c}188 \mathrm{R}-5 \\
13-18\end{array}$ & $\begin{array}{c}168 \mathrm{R}-5 \\
72-78\end{array}$ & $\begin{array}{c}149 \mathrm{R}-1 \\
56-65\end{array}$ & $\begin{array}{c}144 \mathrm{R}-6 \\
108-113\end{array}$ \\
\hline Rock type: & \multicolumn{4}{|c|}{ Troctolite } & \multicolumn{2}{|c|}{ Troctolitic gabbro } & \multicolumn{9}{|c|}{ Olivine gabbro } \\
\hline \multicolumn{16}{|c|}{ Major element oxide (wt\%): } \\
\hline $\mathrm{SiO}_{2}$ & 53.41 & 51.99 & 51.84 & 51.90 & 51.75 & 51.37 & 53.15 & 52.34 & 52.26 & 52.02 & 50.27 & 51.95 & 51.08 & 51.04 & 52.71 \\
\hline $\mathrm{TiO}_{2}$ & 0.38 & 0.52 & 0.41 & 0.42 & 0.38 & 1.25 & 0.29 & 0.48 & 0.60 & 0.62 & 0.96 & 0.59 & 0.85 & 0.78 & 0.35 \\
\hline $\mathrm{Al}_{2} \mathrm{O}_{3}$ & 3.09 & 3.33 & 3.34 & 3.32 & 3.36 & 3.90 & 1.05 & 1.99 & 2.87 & 3.07 & 3.23 & 2.90 & 3.24 & 2.26 & 1.11 \\
\hline $\mathrm{FeO}$ & 5.52 & 5.58 & 4.09 & 6.02 & 6.02 & 3.64 & 12.00 & 9.86 & 7.41 & 7.02 & 8.08 & 6.14 & 7.16 & 8.36 & 9.14 \\
\hline $\mathrm{Cr}_{2} \mathrm{O}_{3}$ & 0.25 & 0.53 & 0.58 & 0.51 & 0.88 & 0.87 & 0.06 & 0.03 & 0.19 & 0.16 & 0.15 & 0.24 & 0.27 & 0.10 & 0.10 \\
\hline $\mathrm{MnO}$ & 0.17 & 0.14 & 0.17 & 0.13 & 0.19 & 0.09 & 0.36 & 0.24 & 0.11 & 0.16 & 0.19 & 0.17 & 0.14 & 0.21 & 0.43 \\
\hline $\mathrm{MgO}$ & 17.37 & 16.93 & 15.89 & 15.89 & 18.88 & 16.57 & 24.38 & 21.34 & 19.54 & 18.11 & 16.53 & 16.37 & 15.31 & 14.40 & 14.05 \\
\hline $\mathrm{CaO}$ & 19.90 & 20.78 & 22.65 & 23.06 & 17.17 & 22.20 & 8.00 & 14.28 & 17.28 & 18.56 & 18.38 & 22.12 & 21.60 & 21.29 & 22.39 \\
\hline $\mathrm{Na}_{2} \mathrm{O}$ & 0.35 & 0.37 & 0.39 & 0.32 & 0.38 & 0.58 & 0.12 & 0.27 & 0.54 & 0.41 & 0.68 & 0.60 & 0.67 & 0.47 & 0.51 \\
\hline Total & 100.44 & 100.17 & 99.36 & 101.57 & 99.01 & 100.48 & 99.41 & 100.83 & 100.79 & 100.12 & 98.47 & 101.07 & 100.31 & 98.91 & 100.79 \\
\hline \multicolumn{16}{|c|}{ Number of cations based on $6 \mathrm{O}$ : } \\
\hline $\mathrm{Si}$ & 1.9367 & 1.9030 & 1.9107 & 1.8901 & 1.9030 & 1.8713 & 1.9441 & 1.9057 & 1.8986 & 1.9047 & 1.8877 & 1.8988 & 1.8895 & 1.9228 & 1.9588 \\
\hline $\mathrm{Ti}$ & 0.0104 & 0.0143 & 0.0114 & 0.0115 & 0.0105 & 0.0343 & 0.0080 & 0.0131 & 0.0164 & 0.0172 & 0.0270 & 0.0161 & 0.0235 & 0.0221 & 0.0097 \\
\hline $\mathrm{Al}^{\mathrm{IV}}$ & 0.0633 & 0.0970 & 0.0893 & 0.1099 & 0.0970 & 0.1287 & 0.0453 & 0.0855 & 0.1014 & 0.0953 & 0.1123 & 0.1012 & 0.1105 & 0.0772 & 0.0412 \\
\hline $\mathrm{Al}^{\mathrm{V}} \mathrm{V}^{\mathrm{I}}$ & 0.0688 & 0.0466 & 0.0558 & 0.0326 & 0.0487 & 0.0386 & 0.0000 & 0.0000 & 0.0213 & 0.0369 & 0.0306 & 0.0239 & 0.0308 & 0.0230 & 0.0073 \\
\hline $\mathrm{Fe}^{+2}$ & 0.1674 & 0.1708 & 0.1260 & 0.1834 & 0.1851 & 0.1109 & 0.3670 & 0.3003 & 0.2250 & 0.2148 & 0.2537 & 0.1875 & 0.2214 & 0.2633 & 0.2839 \\
\hline $\mathrm{Cr}$ & 0.0072 & 0.0153 & 0.0169 & 0.0147 & 0.0256 & 0.0249 & 0.0017 & 0.0009 & 0.0054 & 0.0045 & 0.0044 & 0.0070 & 0.0078 & 0.0030 & 0.0030 \\
\hline $\mathrm{Mn}$ & 0.0052 & 0.0043 & 0.0053 & 0.0040 & 0.0059 & 0.0027 & 0.0112 & 0.0073 & 0.0034 & 0.0049 & 0.0061 & 0.0054 & 0.0044 & 0.0068 & 0.0137 \\
\hline $\mathrm{Mg}$ & 0.9390 & 0.9238 & 0.8731 & 0.8627 & 1.0351 & 0.8999 & 1.3294 & 1.1582 & 1.0580 & 0.9887 & 0.9256 & 0.8918 & 0.8446 & 0.8088 & 0.7786 \\
\hline $\mathrm{Ca}$ & 0.7731 & 0.8149 & 0.8944 & 0.8997 & 0.6764 & 0.8664 & 0.3135 & 0.5575 & 0.6724 & 0.7281 & 0.7394 & 0.8662 & 0.8559 & 0.8594 & 0.8912 \\
\hline $\mathrm{Na}$ & 0.0694 & 0.0718 & 0.0768 & 0.0611 & 0.0741 & 0.1093 & 0.0242 & 0.0522 & 0.1034 & 0.0799 & 0.1344 & 0.1155 & 0.1296 & 0.0950 & 0.1061 \\
\hline Total & 4.0404 & 4.0619 & 4.0597 & 4.0696 & 4.0614 & 4.0871 & 4.0444 & 4.0807 & 4.1054 & 4.0751 & 4.1211 & 4.1134 & 4.1180 & 4.0814 & 4.0935 \\
\hline En & 50.0 & 48.4 & 46.1 & 44.4 & 54.5 & 47.9 & 66.1 & 57.4 & 54.1 & 51.2 & 48.3 & 45.9 & 44.0 & 41.9 & 39.9 \\
\hline $\mathrm{Fe}$ & 8.9 & 8.9 & 6.7 & 9.4 & 9.8 & 5.9 & 18.3 & 14.9 & 11.5 & 11.1 & 13.2 & 9.6 & 11.5 & 13.6 & 14.5 \\
\hline Wo & 41.1 & 42.7 & 47.2 & 46.2 & 35.7 & 46.2 & 15.6 & 27.7 & 34.4 & 37.7 & 38.5 & 44.5 & 44.5 & 44.5 & 45.6 \\
\hline
\end{tabular}

Note: $\mathrm{En}=$ enstatite, $\mathrm{Fe}=$ ferrosilite, $\mathrm{Wo}=$ wollastonite. 
Table T7 (continued).

\begin{tabular}{|c|c|c|c|c|c|c|c|c|c|c|c|c|c|c|c|}
\hline \multirow{2}{*}{$\begin{array}{l}\text { Leg, hole: } \\
\text { Core, section: } \\
\text { Interval }(\mathrm{cm}) \text { : }\end{array}$} & \multicolumn{3}{|c|}{ 176-735B- } & \multicolumn{2}{|c|}{$118-735 \mathrm{~B}-$} & \multirow{2}{*}{ 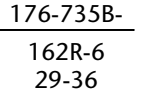 } & \multicolumn{9}{|c|}{$118-735 \mathrm{~B}-$} \\
\hline & $\begin{array}{c}190 \mathrm{R}-6 \\
42-48\end{array}$ & $\begin{array}{c}190 \mathrm{R}-6 \\
42-48\end{array}$ & $\begin{array}{c}190 \mathrm{R}-6 \\
42-48\end{array}$ & $\begin{array}{l}23 R-5 \\
47-52\end{array}$ & $\begin{array}{c}18 \mathrm{R}-4 \\
139-147\end{array}$ & & $\begin{array}{c}35 \mathrm{R}-6 \\
95-102\end{array}$ & $\begin{array}{l}28 R-2 \\
76-83\end{array}$ & $\begin{array}{l}20 \mathrm{R}-2 \\
13-21\end{array}$ & $\begin{array}{l}38 \mathrm{R}-1 \\
61-80\end{array}$ & $\begin{array}{l}52 \mathrm{R}-4 \\
69-71\end{array}$ & $\begin{array}{l}53 R-4 \\
68-78\end{array}$ & $\begin{array}{l}19 R-5 \\
62-73\end{array}$ & $\begin{array}{c}\text { 2D-1 } \\
145-148\end{array}$ & $\begin{array}{c}2 \mathrm{D}-1 \\
145-148\end{array}$ \\
\hline Rock type: & \multicolumn{4}{|c|}{ Gabbro } & \multicolumn{8}{|c|}{ Oxide gabbro } & \multicolumn{3}{|c|}{ Gabbronorite } \\
\hline \multicolumn{16}{|c|}{ Major element oxide (wt\%): } \\
\hline $\mathrm{SiO}_{2}$ & 52.18 & 52.07 & 51.05 & 51.10 & 52.91 & 51.98 & 51.45 & 50.86 & 50.82 & 50.99 & 49.65 & 51.45 & 51.22 & 51.34 & 50.37 \\
\hline $\mathrm{TiO}_{2}$ & 0.62 & 0.52 & 0.81 & 0.49 & 0.45 & 0.64 & 0.64 & 0.67 & 1.02 & 0.62 & 0.69 & 0.15 & 0.43 & 0.50 & 0.57 \\
\hline $\mathrm{Al}_{2} \mathrm{O}_{3}$ & 1.82 & 2.21 & 2.54 & 2.84 & 3.29 & 2.72 & 3.70 & 3.64 & 2.72 & 1.88 & 1.78 & 0.53 & 2.41 & 1.95 & 2.34 \\
\hline $\mathrm{FeO}$ & 12.21 & 9.17 & 7.90 & 7.36 & 10.41 & 7.31 & 5.94 & 5.94 & 9.04 & 13.44 & 13.47 & 14.98 & 11.21 & 11.31 & 11.41 \\
\hline $\mathrm{Cr}_{2} \mathrm{O}_{3}$ & 0.04 & 0.14 & 0.08 & 0.08 & 0.20 & 0.11 & 0.20 & 0.17 & 0.18 & 0.00 & 0.00 & 0.02 & 0.15 & 0.00 & 0.00 \\
\hline $\mathrm{MnO}$ & 0.33 & 0.26 & 0.21 & 0.28 & 0.19 & 0.12 & 0.16 & 0.16 & 0.28 & 0.43 & 0.49 & 0.48 & 0.34 & 0.41 & 0.37 \\
\hline $\mathrm{MgO}$ & 21.36 & 17.99 & 16.07 & 14.08 & 22.24 & 18.06 & 16.67 & 15.27 & 13.81 & 12.93 & 11.66 & 11.25 & 13.49 & 13.01 & 12.55 \\
\hline $\mathrm{CaO}$ & 11.60 & 17.20 & 20.58 & 21.43 & 9.27 & 19.14 & 19.81 & 21.10 & 19.79 & 18.37 & 20.31 & 21.43 & 19.51 & 20.33 & 20.95 \\
\hline $\mathrm{Na}_{2} \mathrm{O}$ & 0.36 & 0.30 & 0.41 & 0.45 & 0.43 & 0.44 & 0.59 & 0.43 & 0.58 & 0.40 & 0.43 & 0.34 & 0.52 & 0.39 & 0.47 \\
\hline Total & 100.52 & 99.85 & 99.65 & 98.11 & 99.39 & 100.52 & 99.16 & 98.24 & 98.24 & 99.07 & 98.48 & 100.63 & 99.28 & 99.24 & 99.03 \\
\hline \multicolumn{16}{|c|}{ Number of cations based on 60 : } \\
\hline $\mathrm{Si}$ & 1.9128 & 1.9236 & 1.9012 & 1.9304 & 1.9250 & 1.9027 & 1.9009 & 1.9043 & 1.9256 & 1.9463 & 1.9254 & 1.9653 & 1.9365 & 1.9467 & 1.9225 \\
\hline $\mathrm{Ti}$ & 0.0170 & 0.0144 & 0.0228 & 0.0139 & 0.0123 & 0.0175 & 0.0170 & 0.0189 & 0.0291 & 0.0177 & 0.0201 & 0.0043 & 0.0122 & 0.0143 & 0.0164 \\
\hline $\mathrm{Al}^{\mathrm{IV}}$ & 0.0786 & 0.0764 & 0.0988 & 0.0696 & 0.0750 & 0.0973 & 0.0991 & 0.0957 & 0.0744 & 0.0537 & 0.0746 & 0.0239 & 0.0635 & 0.0533 & 0.0775 \\
\hline $\mathrm{Al}^{\mathrm{V}} \mathrm{V}^{\mathrm{I}}$ & 0.0000 & 0.0197 & 0.0128 & 0.0568 & 0.0660 & 0.0201 & 0.0621 & 0.0649 & 0.0471 & 0.0310 & 0.0067 & 0.0000 & 0.0438 & 0.0338 & 0.0278 \\
\hline $\mathrm{Fe}^{+2}$ & 0.3744 & 0.2831 & 0.2462 & 0.2325 & 0.3166 & 0.2237 & 0.1836 & 0.1859 & 0.2866 & 0.4291 & 0.4368 & 0.4785 & 0.3543 & 0.3586 & 0.3642 \\
\hline $\mathrm{Cr}$ & 0.0013 & 0.0040 & 0.0024 & 0.0024 & 0.0058 & 0.0031 & 0.0058 & 0.0050 & 0.0054 & 0.0000 & 0.0000 & 0.0006 & 0.0045 & 0.0000 & 0.0000 \\
\hline $\mathrm{Mn}$ & 0.0103 & 0.0083 & 0.0066 & 0.0090 & 0.0059 & 0.0037 & 0.0050 & 0.0051 & 0.0090 & 0.0140 & 0.0161 & 0.0155 & 0.0109 & 0.0132 & 0.0120 \\
\hline $\mathrm{Mg}$ & 1.1673 & 0.9910 & 0.8922 & 0.7930 & 1.2063 & 0.9855 & 0.9182 & 0.8523 & 0.7801 & 0.7357 & 0.6741 & 0.6406 & 0.7603 & 0.7354 & 0.7141 \\
\hline $\mathrm{Ca}$ & 0.4557 & 0.6808 & 0.8212 & 0.8673 & 0.3613 & 0.7506 & 0.7841 & 0.8464 & 0.8034 & 0.7513 & 0.8438 & 0.8770 & 0.7902 & 0.8259 & 0.8567 \\
\hline $\mathrm{Na}$ & 0.0710 & 0.0598 & 0.0809 & 0.0924 & 0.0846 & 0.0844 & 0.1154 & 0.0855 & 0.1190 & 0.0846 & 0.0903 & 0.0730 & 0.1075 & 0.0817 & 0.0968 \\
\hline Total & 4.0884 & 4.0610 & 4.0850 & 4.0673 & 4.0588 & 4.0886 & 4.0912 & 4.0639 & 4.0796 & 4.0634 & 4.0879 & 4.0786 & 4.0838 & 4.0628 & 4.0879 \\
\hline En & 58.5 & 50.7 & 45.5 & 41.9 & 64.0 & 50.3 & 48.7 & 45.2 & 41.7 & 38.4 & 34.5 & 32.1 & 39.9 & 38.3 & 36.9 \\
\hline $\mathrm{Fe}$ & 18.7 & 14.5 & 12.6 & 12.3 & 16.8 & 11.4 & 9.7 & 9.9 & 15.3 & 22.4 & 22.3 & 24.0 & 18.6 & 18.7 & 18.8 \\
\hline Wo & 22.8 & 34.8 & 41.9 & 45.8 & 19.2 & 38.3 & 41.6 & 44.9 & 43.0 & 39.2 & 43.2 & 43.9 & 41.5 & 43.0 & 44.3 \\
\hline
\end{tabular}


Table T7 (continued).

\begin{tabular}{|c|c|c|c|c|c|c|}
\hline \multirow{2}{*}{$\begin{array}{l}\text { Leg, hole: } \\
\text { Core, section: } \\
\text { Interval }(\mathrm{cm}) \text { : }\end{array}$} & \multicolumn{2}{|c|}{ 176-735B- } & \multicolumn{4}{|c|}{ 118-735B- } \\
\hline & $\begin{array}{c}154 R-3 \\
71-79\end{array}$ & $\begin{array}{c}154 R-3 \\
71-79\end{array}$ & $\begin{array}{c}44 R-2 \\
0-4\end{array}$ & $\begin{array}{l}77 R-4 \\
70-72\end{array}$ & $\begin{array}{l}\text { 77R-4 } \\
70-72\end{array}$ & $\begin{array}{l}\text { 77R-4 } \\
70-72\end{array}$ \\
\hline Rock type: & \multicolumn{6}{|c|}{ Oxide gabbronorite } \\
\hline \multicolumn{7}{|c|}{ Major element oxide (wt\%): } \\
\hline $\mathrm{SiO}_{2}$ & 51.15 & 51.99 & 51.33 & 51.03 & 51.48 & 51.43 \\
\hline $\mathrm{TiO}_{2}$ & 0.73 & 0.55 & 0.80 & 0.40 & 0.55 & 0.20 \\
\hline $\mathrm{Al}_{2} \mathrm{O}_{3}$ & 2.45 & 1.76 & 2.57 & 1.03 & 1.69 & 0.85 \\
\hline $\mathrm{FeO}$ & 9.60 & 8.30 & 10.96 & 19.57 & 14.48 & 13.36 \\
\hline $\mathrm{Cr}_{2} \mathrm{O}_{3}$ & 0.00 & 0.10 & 0.01 & 0.02 & 0.04 & 0.03 \\
\hline $\mathrm{MnO}$ & 0.27 & 0.13 & 0.39 & 0.62 & 0.41 & 0.44 \\
\hline $\mathrm{MgO}$ & 15.00 & 14.68 & 13.58 & 13.21 & 13.01 & 12.52 \\
\hline $\mathrm{CaO}$ & 19.80 & 22.16 & 20.28 & 15.28 & 18.79 & 20.96 \\
\hline $\mathrm{Na}_{2} \mathrm{O}$ & 0.62 & 0.58 & 0.53 & 0.30 & 0.41 & 0.33 \\
\hline Total & 99.62 & 100.25 & 100.45 & 101.46 & 100.86 & 100.12 \\
\hline \multicolumn{7}{|c|}{ Number of cations based on 60 : } \\
\hline $\mathrm{Si}$ & 1.9162 & 1.9341 & 1.9201 & 1.9409 & 1.9402 & 1.9570 \\
\hline $\mathrm{Ti}$ & 0.0207 & 0.0154 & 0.0225 & 0.0114 & 0.0156 & 0.0057 \\
\hline $\mathrm{Al}^{\mathrm{IV}}$ & 0.0838 & 0.0659 & 0.0799 & 0.0462 & 0.0598 & 0.0381 \\
\hline $\mathrm{Al}^{\mathrm{V} \mathrm{V}}$ & 0.0243 & 0.0114 & 0.0334 & 0.0000 & 0.0153 & 0.0000 \\
\hline $\mathrm{Fe}^{+2}$ & 0.3006 & 0.2582 & 0.3428 & 0.6224 & 0.4563 & 0.4251 \\
\hline $\mathrm{Cr}$ & 0.0000 & 0.0030 & 0.0003 & 0.0006 & 0.0012 & 0.0009 \\
\hline $\mathrm{Mn}$ & 0.0086 & 0.0042 & 0.0124 & 0.0200 & 0.0131 & 0.0142 \\
\hline $\mathrm{Mg}$ & 0.8377 & 0.8142 & 0.7573 & 0.7490 & 0.7310 & 0.7102 \\
\hline $\mathrm{Ca}$ & 0.7947 & 0.8832 & 0.8127 & 0.6226 & 0.7587 & 0.8544 \\
\hline $\mathrm{Na}$ & 0.1244 & 0.1173 & 0.1068 & 0.0627 & 0.0848 & 0.0700 \\
\hline Total & 4.1110 & 4.1069 & 4.0882 & 4.0759 & 4.0759 & 4.0757 \\
\hline En & 43.3 & 41.6 & 39.6 & 37.6 & 37.6 & 35.7 \\
\hline $\mathrm{Fe}$ & 15.6 & 13.2 & 17.9 & 31.2 & 23.4 & 21.4 \\
\hline Wo & 41.1 & 45.2 & 42.5 & 31.2 & 39.0 & 42.9 \\
\hline
\end{tabular}


Table T8. Representative plagioclase composition for the major rock types, Hole 735B. (Continued on next four pages.)

\begin{tabular}{|c|c|c|c|c|c|c|c|c|c|c|c|c|c|c|c|c|}
\hline \multirow{2}{*}{$\begin{array}{l}\text { Leg, hole: } \\
\text { Core, section: } \\
\text { Interval }(\mathrm{cm}) \text { : }\end{array}$} & \multicolumn{8}{|c|}{ 118-735B- } & \multicolumn{6}{|c|}{ 176-735B- } & \multirow{2}{*}{$\begin{array}{c}118-735 \mathrm{~B}- \\
87 \mathrm{R}-6 \\
31-41\end{array}$} & \multirow{2}{*}{$\begin{array}{c}\text { 176-735B- } \\
205 R-4 \\
40-45\end{array}$} \\
\hline & $\begin{array}{c}87 R-6 \\
106-114\end{array}$ & $\begin{array}{c}87 R-7 \\
0-7\end{array}$ & $\begin{array}{c}87 R-7 \\
0-7\end{array}$ & $\begin{array}{c}87 R-7 \\
0-7\end{array}$ & $\begin{array}{c}\text { 79R-6 } \\
105-111\end{array}$ & $\begin{array}{c}\text { 79R-6 } \\
105-111\end{array}$ & $\begin{array}{l}83 R-6 \\
53-59\end{array}$ & $\begin{array}{c}85 \mathrm{R}-7 \\
0-5\end{array}$ & $\begin{array}{l}\text { 91R-5 } \\
81-86\end{array}$ & $\begin{array}{l}91 \mathrm{R}-3 \\
67-72\end{array}$ & $\begin{array}{l}\text { 91R-3 } \\
67-72\end{array}$ & $\begin{array}{l}\text { 91R-5 } \\
81-86\end{array}$ & $\begin{array}{c}144 \mathrm{R}-1 \\
113-122\end{array}$ & $\begin{array}{c}141 \mathrm{R}-1 \\
50-55\end{array}$ & & \\
\hline Rock type: & \multicolumn{4}{|c|}{ Troctolite } & \multicolumn{4}{|c|}{ Troctolitic gabbro } & \multicolumn{8}{|c|}{ Olivine gabbro } \\
\hline \multicolumn{17}{|c|}{ Major element oxide (wt\%): } \\
\hline $\mathrm{SiO}_{2}$ & 51.71 & 51.63 & 51.90 & 55.67 & 48.22 & 49.39 & 49.06 & 51.78 & 49.37 & 50.00 & 51.24 & 52.04 & 52.68 & 53.74 & 53.14 & 53.78 \\
\hline $\mathrm{TiO}_{2}$ & 0.00 & 0.00 & 0.00 & 0.00 & 0.00 & 0.00 & 0.00 & 0.00 & 0.00 & 0.04 & 0.09 & 0.03 & 0.05 & 0.00 & 0.04 & 0.00 \\
\hline $\mathrm{Al}_{2} \mathrm{O}_{3}$ & 30.95 & 30.46 & 29.71 & 27.60 & 32.88 & 32.40 & 32.38 & 30.86 & 32.44 & 31.85 & 31.02 & 30.96 & 29.63 & 28.85 & 29.32 & 28.84 \\
\hline $\mathrm{Fe}_{2} \mathrm{O}_{3}$ & 0.12 & 0.18 & 0.22 & 0.14 & 0.07 & 0.07 & 0.06 & 0.21 & 0.07 & 0.13 & 0.07 & 0.00 & 0.32 & 0.22 & 0.24 & 0.38 \\
\hline $\mathrm{CaO}$ & 13.85 & 13.24 & 12.41 & 10.06 & 16.19 & 15.44 & 15.31 & 13.87 & 15.34 & 15.00 & 14.02 & 13.10 & 12.83 & 12.22 & 11.86 & 11.92 \\
\hline $\mathrm{Na}_{2} \mathrm{O}$ & 3.72 & 4.05 & 4.19 & 6.08 & 2.51 & 2.82 & 3.26 & 3.15 & 2.96 & 3.11 & 3.78 & 4.17 & 4.59 & 4.76 & 4.62 & 5.34 \\
\hline $\mathrm{K}_{2} \mathrm{O}$ & 0.01 & 0.05 & 0.03 & 0.03 & 0.00 & 0.00 & 0.00 & 0.12 & 0.00 & 0.05 & 0.01 & 0.00 & 0.04 & 0.06 & 0.03 & 0.04 \\
\hline $\mathrm{BaO}$ & 0.00 & 0.00 & 0.05 & 0.00 & 0.00 & 0.00 & 0.00 & 0.00 & 0.00 & 0.10 & 0.12 & 0.00 & 0.15 & 0.00 & 0.00 & 0.08 \\
\hline Total & 100.36 & 99.61 & 98.52 & 99.58 & 99.87 & 100.12 & 100.07 & 99.99 & 100.19 & 100.28 & 100.35 & 100.29 & 100.29 & 99.85 & 99.25 & 100.38 \\
\hline \multicolumn{17}{|c|}{ Number of cations based on $8 \mathrm{O}$ : } \\
\hline $\mathrm{Si}$ & 2.3409 & 2.3542 & 2.3866 & 2.5165 & 2.2117 & 2.2526 & 2.2429 & 2.3491 & 2.2507 & 2.2771 & 2.3256 & 2.3530 & 2.3883 & 2.4361 & 2.4203 & 2.4310 \\
\hline $\mathrm{Ti}$ & 0.0000 & 0.0000 & 0.0000 & 0.0000 & 0.0000 & 0.0000 & 0.0000 & 0.0000 & 0.0000 & 0.0014 & 0.0031 & 0.0011 & 0.0016 & 0.0000 & 0.0014 & 0.0000 \\
\hline Allv & 1.6513 & 1.6369 & 1.6102 & 1.4704 & 1.7774 & 1.7415 & 1.7446 & 1.6500 & 1.7431 & 1.7095 & 1.6592 & 1.6470 & 1.5833 & 1.5416 & 1.5739 & 1.5365 \\
\hline $\mathrm{Al}^{\mathrm{V} \mathrm{V}^{\mathrm{I}}}$ & 0.0000 & 0.0000 & 0.0000 & 0.0000 & 0.0000 & 0.0000 & 0.0000 & 0.0000 & 0.0000 & 0.0000 & 0.0000 & 0.0030 & 0.0000 & 0.0000 & 0.0000 & 0.0000 \\
\hline $\mathrm{Fe}^{+3}$ & 0.0041 & 0.0062 & 0.0077 & 0.0048 & 0.0024 & 0.0024 & 0.0021 & 0.0072 & 0.0026 & 0.0045 & 0.0024 & 0.0000 & 0.0110 & 0.0075 & 0.0082 & 0.0130 \\
\hline $\mathrm{Ca}$ & 0.6717 & 0.6468 & 0.6113 & 0.4872 & 0.7955 & 0.7544 & 0.7499 & 0.6741 & 0.7493 & 0.7318 & 0.6817 & 0.6344 & 0.6233 & 0.5933 & 0.5787 & 0.5773 \\
\hline $\mathrm{Na}$ & 0.3265 & 0.3580 & 0.3739 & 0.5328 & 0.2232 & 0.2493 & 0.2889 & 0.2771 & 0.2616 & 0.2746 & 0.3326 & 0.3651 & 0.4036 & 0.4185 & 0.4079 & 0.4678 \\
\hline $\mathrm{K}$ & 0.0006 & 0.0029 & 0.0018 & 0.0017 & 0.0000 & 0.0000 & 0.0000 & 0.0069 & 0.0000 & 0.0029 & 0.0006 & 0.0000 & 0.0024 & 0.0035 & 0.0017 & 0.0022 \\
\hline $\mathrm{Ba}$ & 0.0000 & 0.0000 & 0.0009 & 0.0000 & 0.0000 & 0.0000 & 0.0000 & 0.0000 & 0.0000 & 0.0018 & 0.0021 & 0.0000 & 0.0026 & 0.0000 & 0.0000 & 0.0014 \\
\hline Total ions & 4.9951 & 5.0049 & 4.9924 & 5.0133 & 5.0102 & 5.0003 & 5.0284 & 4.9644 & 5.0074 & 5.0035 & 5.0073 & 5.0036 & 5.0161 & 5.0005 & 4.9922 & 5.0293 \\
\hline An & 67.3 & 64.2 & 61.9 & 47.7 & 78.1 & 75.2 & 72.2 & 70.4 & 74.1 & 72.5 & 67.2 & 63.5 & 60.6 & 58.4 & 58.6 & 55.1 \\
\hline $\mathrm{Ab}$ & 32.7 & 35.5 & 37.9 & 52.1 & 21.9 & 24.8 & 27.8 & 28.9 & 25.9 & 27.2 & 32.8 & 36.5 & 39.2 & 41.2 & 41.3 & 44.7 \\
\hline Or & 0.1 & 0.3 & 0.2 & 0.2 & 0.0 & 0.0 & 0.0 & 0.7 & 0.0 & 0.3 & 0.1 & 0.0 & 0.2 & 0.3 & 0.2 & 0.2 \\
\hline
\end{tabular}

Note: $\mathrm{An}=$ anorthite, $\mathrm{Ab}=$ albite $\mathrm{Or}=$ orthoclase. 
Table T8 (continued).

\begin{tabular}{|c|c|c|c|c|c|c|c|c|c|c|c|c|c|c|c|}
\hline \multirow{2}{*}{$\begin{array}{l}\text { Leg, hole: } \\
\text { Core, section: } \\
\text { Interval }(\mathrm{cm}) \text { : }\end{array}$} & \multirow{2}{*}{$\begin{array}{c}118-735 \mathrm{~B}- \\
79 \mathrm{R}-7 \\
104-109\end{array}$} & \multicolumn{2}{|c|}{ 176-735B- } & \multicolumn{2}{|c|}{ 118-735B- } & \multicolumn{3}{|c|}{ 176-735B- } & \multicolumn{3}{|c|}{ 118-735B- } & \multicolumn{2}{|c|}{ 176-735B- } & \multicolumn{2}{|c|}{ 118-735B- } \\
\hline & & $\begin{array}{c}143 R-6 \\
1-6\end{array}$ & $\begin{array}{c}143 R-6 \\
1-6\end{array}$ & $\begin{array}{l}12 \mathrm{R}-1 \\
50-55\end{array}$ & $\begin{array}{c}19 \mathrm{R}-1 \\
140-146\end{array}$ & $\begin{array}{c}158 \mathrm{R}-1 \\
69-75\end{array}$ & $\begin{array}{c}145 R-5 \\
49-53\end{array}$ & $\begin{array}{c}142 \mathrm{R}-1 \\
76-80\end{array}$ & $\begin{array}{c}\text { 36R-1 } \\
111-117\end{array}$ & $\begin{array}{c}15 \mathrm{R}-2 \\
128-130\end{array}$ & $\begin{array}{l}\text { 30R-1 } \\
50-56\end{array}$ & $\begin{array}{c}144 \mathrm{R}-6 \\
108-113\end{array}$ & $\begin{array}{c}190 \mathrm{R}-6 \\
42-48\end{array}$ & $\begin{array}{l}23 R-5 \\
47-52\end{array}$ & $\begin{array}{l}23 R-5 \\
47-52\end{array}$ \\
\hline Rock type: & \multicolumn{12}{|c|}{ Olivine gabbro } & \multicolumn{3}{|c|}{ Gabbro } \\
\hline \multicolumn{16}{|c|}{ Major element oxide (wt\%): } \\
\hline $\mathrm{SiO}_{2}$ & 53.25 & 56.96 & 58.18 & 57.85 & 58.14 & 60.02 & 61.02 & 62.37 & 61.57 & 62.90 & 64.57 & 67.28 & 52.67 & 53.59 & 54.10 \\
\hline $\mathrm{TiO}_{2}$ & 0.00 & 0.13 & 0.00 & 0.00 & 0.00 & 0.03 & 0.00 & 0.04 & 0.00 & 0.00 & 0.00 & 0.00 & 0.05 & 0.00 & 0.00 \\
\hline $\mathrm{Al}_{2} \mathrm{O}_{3}$ & 29.60 & 26.48 & 26.06 & 25.46 & 26.25 & 25.09 & 24.17 & 23.83 & 24.15 & 22.78 & 22.34 & 20.71 & 29.16 & 29.59 & 28.45 \\
\hline $\mathrm{Fe}_{2} \mathrm{O}_{3}$ & 0.14 & 0.19 & 0.00 & 0.20 & 0.11 & 0.16 & 0.23 & 0.23 & 0.15 & 0.01 & 0.14 & 0.02 & 0.36 & 0.05 & 0.10 \\
\hline $\mathrm{CaO}$ & 10.98 & 9.69 & 8.44 & 7.82 & 7.44 & 7.04 & 6.22 & 5.49 & 4.57 & 4.34 & 2.21 & 1.55 & 12.35 & 11.42 & 11.25 \\
\hline $\mathrm{Na}_{2} \mathrm{O}$ & 5.08 & 6.16 & 6.75 & 7.03 & 7.32 & 7.53 & 8.18 & 8.76 & 8.86 & 9.28 & 9.71 & 11.24 & 4.85 & 4.95 & 5.22 \\
\hline $\mathrm{K}_{2} \mathrm{O}$ & 0.05 & 0.29 & 0.29 & 0.05 & 0.02 & 0.34 & 0.15 & 0.01 & 0.06 & 0.01 & 0.01 & 0.11 & 0.07 & 0.01 & 0.04 \\
\hline $\mathrm{BaO}$ & 0.00 & 0.00 & 0.18 & 0.00 & 0.00 & 0.20 & 0.05 & 0.00 & 0.00 & 0.00 & 0.03 & 0.03 & 0.10 & 0.00 & 0.00 \\
\hline Total & 99.10 & 99.91 & 99.91 & 98.42 & 99.28 & 100.42 & 100.02 & 100.74 & 99.36 & 99.32 & 99.03 & 100.94 & 99.61 & 99.61 & 99.16 \\
\hline \multicolumn{16}{|c|}{ Number of cations based on $8 \mathrm{O}$ : } \\
\hline $\mathrm{Si}$ & 2.4245 & 2.5646 & 2.6107 & 2.6272 & 2.6147 & 2.6710 & 2.7159 & 2.7481 & 2.7436 & 2.7997 & 2.8603 & 2.9279 & 2.4026 & 2.4279 & 2.4627 \\
\hline $\mathrm{Ti}$ & 0.0000 & 0.0044 & 0.0000 & 0.0000 & 0.0000 & 0.0010 & 0.0000 & 0.0013 & 0.0001 & 0.0000 & 0.0001 & 0.0000 & 0.0017 & 0.0000 & 0.0000 \\
\hline Allv & 1.5755 & 1.4052 & 1.3782 & 1.3628 & 1.3853 & 1.3162 & 1.2680 & 1.2376 & 1.2564 & 1.1950 & 1.1397 & 1.0622 & 1.5673 & 1.5721 & 1.5263 \\
\hline $\mathrm{Al}^{\mathrm{V} \mathrm{V}^{\mathrm{I}}}$ & 0.0129 & 0.0000 & 0.0000 & 0.0000 & 0.0060 & 0.0000 & 0.0000 & 0.0000 & 0.0119 & 0.0000 & 0.0266 & 0.0000 & 0.0000 & 0.0078 & 0.0000 \\
\hline $\mathrm{Fe}^{+3}$ & 0.0048 & 0.0065 & 0.0001 & 0.0069 & 0.0037 & 0.0053 & 0.0077 & 0.0076 & 0.0050 & 0.0003 & 0.0046 & 0.0007 & 0.0125 & 0.0017 & 0.0034 \\
\hline $\mathrm{Ca}$ & 0.5356 & 0.4673 & 0.4060 & 0.3804 & 0.3585 & 0.3359 & 0.2965 & 0.2591 & 0.2181 & 0.2070 & 0.1050 & 0.0721 & 0.6034 & 0.5543 & 0.5486 \\
\hline $\mathrm{Na}$ & 0.4484 & 0.5380 & 0.5875 & 0.6187 & 0.6382 & 0.6499 & 0.7063 & 0.7484 & 0.7656 & 0.8008 & 0.8339 & 0.9481 & 0.4292 & 0.4348 & 0.4607 \\
\hline $\mathrm{K}$ & 0.0029 & 0.0168 & 0.0167 & 0.0029 & 0.0011 & 0.0191 & 0.0086 & 0.0006 & 0.0036 & 0.0006 & 0.0006 & 0.0063 & 0.0043 & 0.0006 & 0.0023 \\
\hline $\mathrm{Ba}$ & 0.0000 & 0.0000 & 0.0031 & 0.0000 & 0.0000 & 0.0036 & 0.0009 & 0.0000 & 0.0000 & 0.0000 & 0.0006 & 0.0005 & 0.0017 & 0.0000 & 0.0000 \\
\hline Total ions & 5.0046 & 5.0027 & 5.0023 & 4.9989 & 5.0076 & 5.0019 & 5.0038 & 5.0026 & 5.0043 & 5.0034 & 4.9714 & 5.0179 & 5.0227 & 4.9991 & 5.0041 \\
\hline An & 54.3 & 45.7 & 40.2 & 38.0 & 35.9 & 33.4 & 29.3 & 25.7 & 22.1 & 20.5 & 11.2 & 7.0 & 58.2 & 56.0 & 54.2 \\
\hline $\mathrm{Ab}$ & 45.4 & 52.6 & 58.2 & 61.7 & 64.0 & 64.7 & 69.8 & 74.2 & 77.5 & 79.4 & 88.8 & 92.4 & 41.4 & 43.9 & 45.5 \\
\hline Or & 0.3 & 1.6 & 1.7 & 0.3 & 0.1 & 1.9 & 0.9 & 0.1 & 0.4 & 0.1 & 0.1 & 0.6 & 0.4 & 0.1 & 0.2 \\
\hline
\end{tabular}


Table T8 (continued).

\begin{tabular}{|c|c|c|c|c|c|c|c|c|c|c|c|c|c|c|}
\hline \multirow{2}{*}{$\begin{array}{l}\text { Leg, hole: } \\
\text { Core, section: } \\
\text { Interval }(\mathrm{cm}) \text { : }\end{array}$} & \multicolumn{5}{|c|}{ 176-735B- } & \multirow{2}{*}{$\begin{array}{c}118-735 \mathrm{~B}- \\
38 \mathrm{R}-2 \\
123-129\end{array}$} & \multicolumn{3}{|c|}{ 176-735B- } & \multicolumn{2}{|c|}{ 118-735B- } & \multicolumn{2}{|c|}{ 176-735B- } & \multirow{2}{*}{$\begin{array}{c}118-735 \mathrm{~B}- \\
77 \mathrm{R}-4 \\
70-72\end{array}$} \\
\hline & $\begin{array}{c}147 R-5 \\
67-75\end{array}$ & $\begin{array}{c}149 \mathrm{R}-4 \\
82-87\end{array}$ & $\begin{array}{c}147 R-5 \\
67-75\end{array}$ & $\begin{array}{c}147 R-5 \\
67-75\end{array}$ & $\begin{array}{c}147 R-5 \\
67-75\end{array}$ & & $\begin{array}{c}119 R-5 \\
62-68\end{array}$ & $\begin{array}{c}119 R-5 \\
62-68\end{array}$ & $\begin{array}{l}99 R-4 \\
68-74\end{array}$ & $\begin{array}{l}41 \mathrm{R}-4 \\
68-70\end{array}$ & $\begin{array}{c}35 R-6 \\
95-102\end{array}$ & $\begin{array}{c}137 R-6 \\
68-79\end{array}$ & $\begin{array}{c}118 \mathrm{R}-7 \\
89-95\end{array}$ & \\
\hline Rock type: & \multicolumn{5}{|c|}{ Gabbro } & \multicolumn{9}{|c|}{ Oxide gabbro } \\
\hline \multicolumn{15}{|c|}{ Major element oxide (wt\%): } \\
\hline $\mathrm{SiO}_{2}$ & 54.69 & 54.77 & 55.88 & 56.34 & 57.04 & 52.58 & 54.36 & 54.35 & 55.28 & 56.41 & 57.55 & 59.30 & 59.65 & 60.10 \\
\hline $\mathrm{TiO}_{2}$ & 0.08 & 0.10 & 0.05 & 0.00 & 0.00 & 0.05 & 0.01 & 0.13 & 0.02 & 0.00 & 0.05 & 0.00 & 0.00 & 0.00 \\
\hline $\mathrm{Al}_{2} \mathrm{O}_{3}$ & 28.27 & 28.22 & 27.57 & 27.37 & 26.84 & 29.95 & 28.83 & 28.20 & 28.77 & 28.53 & 26.40 & 25.24 & 24.84 & 25.04 \\
\hline $\mathrm{Fe}_{2} \mathrm{O}_{3}$ & 0.43 & 0.39 & 0.11 & 0.18 & 0.25 & 0.05 & 0.25 & 0.13 & 0.08 & 0.19 & 0.17 & 0.31 & 0.20 & 0.14 \\
\hline $\mathrm{CaO}$ & 11.13 & 10.97 & 10.32 & 10.03 & 9.30 & 12.68 & 12.19 & 11.65 & 10.54 & 9.82 & 8.90 & 7.97 & 7.47 & 6.80 \\
\hline $\mathrm{Na}_{2} \mathrm{O}$ & 5.64 & 5.88 & 6.12 & 6.37 & 6.64 & 4.23 & 4.73 & 5.12 & 5.49 & 6.15 & 6.44 & 7.21 & 7.42 & 7.80 \\
\hline $\mathrm{K}_{2} \mathrm{O}$ & 0.02 & 0.04 & 0.07 & 0.07 & 0.04 & 0.04 & 0.07 & 0.04 & 0.02 & 0.08 & 0.12 & 0.08 & 0.22 & 0.17 \\
\hline $\mathrm{BaO}$ & 0.02 & 0.10 & 0.00 & 0.13 & 0.04 & 0.00 & 0.00 & 0.00 & 0.00 & 0.00 & 0.00 & 0.20 & 0.02 & 0.00 \\
\hline Total & 100.27 & 100.47 & 100.13 & 100.50 & 100.14 & 99.57 & 100.44 & 99.61 & 100.21 & 101.18 & 99.63 & 100.32 & 99.83 & 100.05 \\
\hline \multicolumn{15}{|c|}{ Number of cations based on $8 \mathrm{O}$ : } \\
\hline $\mathrm{Si}$ & 2.4667 & 2.4681 & 2.5152 & 2.5280 & 2.5602 & 2.3909 & 2.4475 & 2.4653 & 2.4821 & 2.5071 & 2.5881 & 2.6469 & 2.6691 & 2.6774 \\
\hline $\mathrm{Ti}$ & 0.0027 & 0.0034 & 0.0018 & 0.0000 & 0.0000 & 0.0016 & 0.0005 & 0.0044 & 0.0008 & 0.0000 & 0.0017 & 0.0000 & 0.0000 & 0.0000 \\
\hline $\mathrm{Al}^{\mathrm{IV}}$ & 1.5027 & 1.4985 & 1.4624 & 1.4476 & 1.4197 & 1.6051 & 1.5300 & 1.5077 & 1.5179 & 1.4929 & 1.3992 & 1.3279 & 1.3098 & 1.3147 \\
\hline $\mathrm{Al}^{\mathrm{VI}}$ & 0.0000 & 0.0000 & 0.0000 & 0.0000 & 0.0000 & 0.0000 & 0.0000 & 0.0000 & 0.0047 & 0.0015 & 0.0000 & 0.0000 & 0.0000 & 0.0000 \\
\hline $\mathrm{Fe}^{+3}$ & 0.0147 & 0.0132 & 0.0036 & 0.0061 & 0.0084 & 0.0016 & 0.0085 & 0.0046 & 0.0027 & 0.0064 & 0.0058 & 0.0103 & 0.0069 & 0.0047 \\
\hline $\mathrm{Ca}$ & 0.5377 & 0.5296 & 0.4977 & 0.4822 & 0.4470 & 0.6177 & 0.5880 & 0.5661 & 0.5070 & 0.4676 & 0.4288 & 0.3811 & 0.3582 & 0.3245 \\
\hline $\mathrm{Na}$ & 0.4932 & 0.5140 & 0.5344 & 0.5544 & 0.5780 & 0.3727 & 0.4128 & 0.4505 & 0.4775 & 0.5299 & 0.5615 & 0.6241 & 0.6440 & 0.6737 \\
\hline $\mathrm{K}$ & 0.0010 & 0.0024 & 0.0041 & 0.0038 & 0.0021 & 0.0023 & 0.0040 & 0.0021 & 0.0014 & 0.0045 & 0.0069 & 0.0046 & 0.0126 & 0.0097 \\
\hline $\mathrm{Ba}$ & 0.0004 & 0.0017 & 0.0000 & 0.0023 & 0.0006 & 0.0000 & 0.0000 & 0.0000 & 0.0000 & 0.0000 & 0.0000 & 0.0036 & 0.0003 & 0.0000 \\
\hline Total ions & 5.0191 & 5.0309 & 5.0193 & 5.0243 & 5.0160 & 4.9918 & 4.9913 & 5.0006 & 4.9941 & 5.0099 & 4.9920 & 4.9984 & 5.0010 & 5.0047 \\
\hline An & 52.1 & 50.6 & 48.0 & 46.4 & 43.5 & 62.2 & 58.5 & 55.6 & 51.4 & 46.7 & 43.0 & 37.7 & 35.3 & 32.2 \\
\hline $\mathrm{Ab}$ & 47.8 & 49.1 & 51.6 & 53.3 & 56.3 & 37.5 & 41.1 & 44.2 & 48.4 & 52.9 & 56.3 & 61.8 & 63.5 & 66.8 \\
\hline Or & 0.1 & 0.2 & 0.4 & 0.4 & 0.2 & 0.2 & 0.4 & 0.2 & 0.1 & 0.5 & 0.7 & 0.5 & 1.2 & 1.0 \\
\hline
\end{tabular}


Table T8 (continued).

\begin{tabular}{|c|c|c|c|c|c|c|c|c|c|c|c|c|c|c|c|}
\hline \multirow{2}{*}{$\begin{array}{l}\text { Leg, hole: } \\
\text { Core, section: } \\
\text { Interval (cm): }\end{array}$} & \multicolumn{2}{|c|}{ 176-735B- } & \multicolumn{13}{|c|}{ 118-735B- } \\
\hline & $\begin{array}{c}118 \mathrm{R}-4 \\
50-55\end{array}$ & $\begin{array}{c}118 \mathrm{R}-4 \\
50-55\end{array}$ & $\begin{array}{l}35 R-3 \\
57-61\end{array}$ & $\begin{array}{c}35 \mathrm{R}-6 \\
95-102\end{array}$ & $\begin{array}{l}56 \mathrm{R}-3 \\
60-65\end{array}$ & $\begin{array}{l}53 R-4 \\
68-78\end{array}$ & $\begin{array}{c}2 \mathrm{D}-1 \\
145-148\end{array}$ & $\begin{array}{l}3 \mathrm{D}-1 \\
7-11\end{array}$ & $\begin{array}{l}19 R-5 \\
62-73\end{array}$ & $\begin{array}{l}19 R-5 \\
62-73\end{array}$ & $\begin{array}{l}19 R-5 \\
62-73\end{array}$ & $\begin{array}{c}2 \mathrm{D}-1 \\
123-127\end{array}$ & $\begin{array}{c}\text { 2D-1 } \\
123-127\end{array}$ & $\begin{array}{c}\text { 2D-1 } \\
123-127\end{array}$ & $\begin{array}{l}74 R-6 \\
27-35\end{array}$ \\
\hline Rock type: & \multicolumn{6}{|c|}{ Oxide gabbro } & \multicolumn{5}{|c|}{ Gabbronorite } & \multicolumn{4}{|c|}{ Oxide gabbronorite } \\
\hline \multicolumn{16}{|c|}{ Major element oxide (wt\%): } \\
\hline $\mathrm{SiO}_{2}$ & 60.86 & 62.38 & 63.35 & 62.88 & 62.70 & 64.13 & 54.60 & 55.73 & 59.59 & 61.18 & 62.32 & 56.16 & 56.40 & 56.57 & 57.40 \\
\hline $\mathrm{TiO}_{2}$ & 0.06 & 0.00 & 0.05 & 0.00 & 0.00 & 0.00 & 0.00 & 0.00 & 0.00 & 0.04 & 0.00 & 0.00 & 0.00 & 0.00 & 0.00 \\
\hline $\mathrm{Al}_{2} \mathrm{O}_{3}$ & 23.86 & 23.47 & 23.38 & 22.74 & 23.39 & 23.56 & 28.98 & 27.46 & 25.12 & 24.22 & 23.56 & 27.15 & 27.37 & 27.90 & 27.30 \\
\hline $\mathrm{Fe}_{2} \mathrm{O}_{3}$ & 0.19 & 0.25 & 0.15 & 0.20 & 0.26 & 0.22 & 0.20 & 0.12 & 0.22 & 0.11 & 0.10 & 0.07 & 0.12 & 0.07 & 0.18 \\
\hline $\mathrm{CaO}$ & 6.50 & 5.86 & 5.24 & 4.57 & 4.17 & 3.58 & 10.19 & 8.68 & 7.11 & 5.69 & 4.90 & 9.86 & 9.47 & 9.02 & 7.91 \\
\hline $\mathrm{Na}_{2} \mathrm{O}$ & 7.79 & 8.18 & 8.10 & 9.03 & 9.29 & 9.53 & 5.96 & 6.20 & 7.42 & 8.04 & 8.75 & 6.17 & 6.27 & 6.20 & 7.23 \\
\hline $\mathrm{K}_{2} \mathrm{O}$ & 0.34 & 0.31 & 0.28 & 0.04 & 0.08 & 0.29 & 0.04 & 0.13 & 0.05 & 0.01 & 0.05 & 0.05 & 0.10 & 0.07 & 0.14 \\
\hline $\mathrm{BaO}$ & 0.00 & 0.14 & 0.00 & 0.00 & 0.00 & 0.00 & 0.00 & 0.00 & 0.00 & 0.00 & 0.00 & 0.00 & 0.00 & 0.05 & 0.00 \\
\hline Total & 99.60 & 100.60 & 100.55 & 99.46 & 99.89 & 101.31 & 99.97 & 98.32 & 99.51 & 99.29 & 99.68 & 99.46 & 99.73 & 99.88 & 100.16 \\
\hline \multicolumn{16}{|c|}{ Number of cations based on $8 \mathrm{O}$ : } \\
\hline $\mathrm{Si}$ & 2.7210 & 2.7571 & 2.7858 & 2.7969 & 2.7779 & 2.7972 & 2.4626 & 2.5400 & 2.6681 & 2.7304 & 2.7673 & 2.5387 & 2.5405 & 2.5386 & 2.5677 \\
\hline $\mathrm{Ti}$ & 0.0020 & 0.0000 & 0.0017 & 0.0000 & 0.0000 & 0.0000 & 0.0000 & 0.0000 & 0.0000 & 0.0013 & 0.0000 & 0.0000 & 0.0000 & 0.0000 & 0.0000 \\
\hline $\mathrm{Al}^{\mathrm{IV}}$ & 1.2572 & 1.2225 & 1.2120 & 1.1921 & 1.2215 & 1.2028 & 1.5374 & 1.4600 & 1.3255 & 1.2696 & 1.2327 & 1.4465 & 1.4530 & 1.4614 & 1.4323 \\
\hline $\mathrm{Al}^{\mathrm{VI}}$ & 0.0000 & 0.0000 & 0.0000 & 0.0000 & 0.0000 & 0.0083 & 0.0030 & 0.0150 & 0.0000 & 0.0043 & 0.0002 & 0.0000 & 0.0000 & 0.0140 & 0.0070 \\
\hline $\mathrm{Fe}^{+3}$ & 0.0063 & 0.0084 & 0.0049 & 0.0067 & 0.0087 & 0.0072 & 0.0068 & 0.0041 & 0.0074 & 0.0037 & 0.0033 & 0.0024 & 0.0041 & 0.0024 & 0.0061 \\
\hline $\mathrm{Ca}$ & 0.3113 & 0.2777 & 0.2468 & 0.2178 & 0.1980 & 0.1673 & 0.4924 & 0.4238 & 0.3410 & 0.2721 & 0.2331 & 0.4775 & 0.4570 & 0.4336 & 0.3791 \\
\hline $\mathrm{Na}$ & 0.6756 & 0.7009 & 0.6906 & 0.7787 & 0.7977 & 0.8059 & 0.5211 & 0.5478 & 0.6441 & 0.6956 & 0.7532 & 0.5407 & 0.5475 & 0.5397 & 0.6270 \\
\hline $\mathrm{K}$ & 0.0192 & 0.0175 & 0.0156 & 0.0023 & 0.0044 & 0.0161 & 0.0023 & 0.0076 & 0.0029 & 0.0006 & 0.0028 & 0.0029 & 0.0057 & 0.0038 & 0.0080 \\
\hline $\mathrm{Ba}$ & 0.0000 & 0.0025 & 0.0000 & 0.0000 & 0.0000 & 0.0000 & 0.0000 & 0.0000 & 0.0000 & 0.0000 & 0.0000 & 0.0000 & 0.0000 & 0.0009 & 0.0000 \\
\hline Total ions & 4.9926 & 4.9866 & 4.9573 & 4.9943 & 5.0082 & 5.0048 & 5.0256 & 4.9983 & 4.9890 & 4.9776 & 4.9927 & 5.0087 & 5.0078 & 4.9943 & 5.0272 \\
\hline An & 30.9 & 27.9 & 25.9 & 21.8 & 19.8 & 16.9 & 48.5 & 43.3 & 34.5 & 28.1 & 23.6 & 46.8 & 45.2 & 44.4 & 37.4 \\
\hline$A b$ & 67.1 & 70.4 & 72.5 & 78.0 & 79.8 & 81.5 & 51.3 & 55.9 & 65.2 & 71.8 & 76.1 & 53.0 & 54.2 & 55.2 & 61.8 \\
\hline Or & 1.9 & 1.8 & 1.6 & 0.2 & 0.4 & 1.6 & 0.2 & 0.8 & 0.3 & 0.1 & 0.3 & 0.3 & 0.6 & 0.4 & 0.8 \\
\hline
\end{tabular}


Table T8 (continued).

\begin{tabular}{|c|c|c|c|c|c|}
\hline \multirow{2}{*}{$\begin{array}{l}\text { Leg, hole: } \\
\text { Core, section: } \\
\text { Interval }(\mathrm{cm}) \text { : }\end{array}$} & \multicolumn{5}{|c|}{ 176-735B- } \\
\hline & $\begin{array}{c}119 \mathrm{R}-1 \\
49-55\end{array}$ & $\begin{array}{c}119 R-1 \\
49-55\end{array}$ & $\begin{array}{c}119 \mathrm{R}-1 \\
49-55\end{array}$ & $\begin{array}{c}119 R-1 \\
49-55\end{array}$ & $\begin{array}{c}119 \mathrm{R}-1 \\
49-55\end{array}$ \\
\hline Rock type: & \multicolumn{5}{|c|}{ Trondhjemetic gabbro } \\
\hline \multicolumn{6}{|c|}{ Major element oxide (wt\%): } \\
\hline $\mathrm{SiO}_{2}$ & 55.07 & 56.60 & 56.60 & 59.99 & 60.74 \\
\hline $\mathrm{TiO}_{2}$ & 0.01 & 0.00 & 0.00 & 0.00 & 0.00 \\
\hline $\mathrm{Al}_{2} \mathrm{O}_{3}$ & 27.50 & 26.79 & 26.79 & 24.65 & 24.32 \\
\hline $\mathrm{Fe}_{2} \mathrm{O}_{3}$ & 0.11 & 0.01 & 0.01 & 0.00 & 0.12 \\
\hline $\mathrm{CaO}$ & 10.60 & 10.16 & 10.16 & 7.16 & 6.65 \\
\hline $\mathrm{Na}_{2} \mathrm{O}$ & 5.73 & 5.94 & 5.94 & 7.53 & 7.93 \\
\hline $\mathrm{K}_{2} \mathrm{O}$ & 0.00 & 0.07 & 0.07 & 0.02 & 0.00 \\
\hline $\mathrm{BaO}$ & 0.00 & 0.11 & 0.11 & 0.00 & 0.16 \\
\hline Total & 99.01 & 99.69 & 99.69 & 99.34 & 99.93 \\
\hline \multicolumn{6}{|c|}{ Number of cations based on $8 \mathrm{O}$ : } \\
\hline $\mathrm{Si}$ & 2.5061 & 2.5538 & 2.5538 & 2.6882 & 2.7071 \\
\hline $\mathrm{Ti}$ & 0.0003 & 0.0001 & 0.0001 & 0.0000 & 0.0000 \\
\hline $\mathrm{Al}^{\mathrm{IV}}$ & 1.4747 & 1.4247 & 1.4247 & 1.3019 & 1.2777 \\
\hline$A l^{\mathrm{VI}}$ & 0.0000 & 0.0000 & 0.0000 & 0.0000 & 0.0000 \\
\hline $\mathrm{Fe}^{+3}$ & 0.0038 & 0.0002 & 0.0002 & 0.0000 & 0.0041 \\
\hline $\mathrm{Ca}$ & 0.5167 & 0.4913 & 0.4913 & 0.3435 & 0.3177 \\
\hline $\mathrm{Na}$ & 0.5054 & 0.5192 & 0.5192 & 0.6538 & 0.6855 \\
\hline $\mathrm{K}$ & 0.0000 & 0.0042 & 0.0042 & 0.0009 & 0.0000 \\
\hline $\mathrm{Ba}$ & 0.0000 & 0.0020 & 0.0020 & 0.0000 & 0.0027 \\
\hline Total ions & 5.0071 & 4.9954 & 4.9954 & 4.9883 & 4.9948 \\
\hline An & 50.6 & 48.4 & 48.4 & 34.4 & 31.7 \\
\hline $\mathrm{Ab}$ & 49.4 & 51.2 & 51.2 & 65.5 & 68.3 \\
\hline Or & 0.0 & 0.4 & 0.4 & 0.1 & 0.0 \\
\hline
\end{tabular}


Table T9. Representative ilmenite compositions for the major rock types, Hole 735B.

\begin{tabular}{|c|c|c|c|c|c|c|c|c|c|c|c|c|c|c|c|}
\hline \multirow{2}{*}{$\begin{array}{l}\text { Leg, hole: } \\
\text { Core, section: } \\
\text { Interval }(\mathrm{cm}) \text { : }\end{array}$} & \multirow{2}{*}{$\begin{array}{c}118-735 \mathrm{~B}- \\
30 \mathrm{R}-1 \\
50-56\end{array}$} & \multicolumn{6}{|c|}{ 176-735B- } & \multicolumn{5}{|c|}{ 118-735B- } & 176-735B- & \multicolumn{2}{|c|}{ 118-735B- } \\
\hline & & $\begin{array}{c}138 \mathrm{R}-4 \\
59-63\end{array}$ & $\begin{array}{c}189 \mathrm{R}-7 \\
75-81\end{array}$ & $\begin{array}{c}142 \mathrm{R}-1 \\
76-80\end{array}$ & $\begin{array}{c}124 \mathrm{R}-1 \\
111-116\end{array}$ & $\begin{array}{c}147 R-5 \\
67-75\end{array}$ & $\begin{array}{c}190 \mathrm{R}-6 \\
42-48\end{array}$ & $\begin{array}{l}28 R-2 \\
76-.83\end{array}$ & $\begin{array}{c}18 \mathrm{R}-4 \\
139-147\end{array}$ & $\begin{array}{c}31 R-1 \\
146-148\end{array}$ & $\begin{array}{l}40 R-5 \\
48-52\end{array}$ & $\begin{array}{c}40 \mathrm{R}-2 \\
103-112\end{array}$ & $\begin{array}{c}157 R-4 \\
0-7\end{array}$ & $\begin{array}{l}19 R-5 \\
62-73\end{array}$ & $\begin{array}{l}19 R-5 \\
62-73\end{array}$ \\
\hline Rock type: & \multicolumn{5}{|c|}{ Olivine gabbro } & \multicolumn{2}{|c|}{ Gabbro } & \multicolumn{6}{|c|}{ Oxide gabbro } & \multicolumn{2}{|c|}{ Gabbronorite } \\
\hline \multicolumn{16}{|c|}{ Major element oxide (wt\%): } \\
\hline $\mathrm{SiO}_{2}$ & 0.02 & 0.16 & 0.17 & 0.22 & 0.19 & 0.24 & 0.19 & 0.00 & 0.00 & 0.04 & 0.14 & 0.04 & 0.16 & 0.09 & 0.04 \\
\hline $\mathrm{TiO}_{2}$ & 50.04 & 49.31 & 49.28 & 47.44 & 47.16 & 48.58 & 49.34 & 51.96 & 51.53 & 50.05 & 49.42 & 48.91 & 48.00 & 51.58 & 50.45 \\
\hline $\mathrm{Fe}_{2} \mathrm{O}_{3}$ & 4.68 & ND & 7.93 & 8.66 & 11.19 & 5.86 & 7.99 & 1.11 & 2.67 & 4.44 & 5.48 & 8.82 & 6.95 & 1.69 & 3.95 \\
\hline $\mathrm{FeO}$ & 43.45 & 45.93 & 38.61 & 41.41 & 37.61 & 41.45 & 38.09 & 45.30 & 44.26 & 43.45 & 42.14 & 39.92 & 41.35 & 44.63 & 44.22 \\
\hline $\mathrm{MnO}$ & 0.78 & 0.41 & 0.53 & 0.60 & 0.41 & 1.48 & 0.39 & 0.87 & 0.81 & 0.81 & 0.92 & 0.77 & 1.27 & 1.22 & 0.97 \\
\hline $\mathrm{MgO}$ & 0.46 & 3.21 & 3.21 & 0.27 & 2.60 & 0.19 & 3.46 & 0.26 & 0.72 & 0.38 & 0.28 & 0.58 & 0.27 & 0.55 & 0.27 \\
\hline $\mathrm{BaO}$ & ND & 0.00 & 0.00 & 0.79 & 0.23 & 1.35 & 0.00 & ND & ND & ND & ND & ND & 0.91 & ND & ND \\
\hline $\mathrm{La}_{2} \mathrm{O}_{3}$ & ND & 0.00 & 0.00 & 0.54 & 0.08 & 0.71 & 0.37 & ND & ND & ND & ND & ND & 0.65 & ND & ND \\
\hline Total & 99.43 & 99.02 & 99.73 & 99.94 & 99.48 & 99.87 & 99.83 & 99.50 & 99.99 & 99.17 & 98.38 & 99.05 & 99.56 & 99.76 & 99.90 \\
\hline \multicolumn{16}{|c|}{ Number of cations based on $6 \mathrm{O}$ : } \\
\hline $\mathrm{Si}$ & 0.0010 & 0.0079 & 0.0085 & 0.0114 & 0.0097 & 0.0123 & 0.0096 & 0.0000 & 0.0000 & 0.0020 & 0.0070 & 0.0018 & 0.0083 & 0.0045 & 0.0020 \\
\hline $\mathrm{Ti}$ & 1.9093 & 1.8377 & 1.8433 & 1.8200 & 1.7800 & 1.8700 & 1.8377 & 1.9801 & 1.9493 & 1.9147 & 1.9030 & 1.8620 & 1.8490 & 1.9585 & 1.9192 \\
\hline $\mathrm{Fe}^{+3}$ & 0.1787 & 0.2895 & 0.2966 & 0.3321 & 0.4218 & 0.2254 & 0.2976 & 0.0423 & 0.1011 & 0.1699 & 0.2110 & 0.3362 & 0.2679 & 0.0640 & 0.1500 \\
\hline $\mathrm{Fe}^{+2}$ & 1.8431 & 1.6205 & 1.6058 & 1.7648 & 1.5756 & 1.7731 & 1.5773 & 1.9193 & 1.8614 & 1.8480 & 1.8034 & 1.6902 & 1.7709 & 1.8840 & 1.8702 \\
\hline $\mathrm{Mn}$ & 0.0335 & 0.0173 & 0.0223 & 0.0259 & 0.0176 & 0.0643 & 0.0164 & 0.0373 & 0.0345 & 0.0349 & 0.0400 & 0.0330 & 0.0550 & 0.0522 & 0.0415 \\
\hline $\mathrm{Mg}$ & 0.0348 & 0.2369 & 0.2235 & 0.0202 & 0.1943 & 0.0147 & 0.2550 & 0.0196 & 0.0540 & 0.0288 & 0.0210 & 0.0440 & 0.0210 & 0.0410 & 0.0200 \\
\hline $\mathrm{Ba}$ & ND & 0.0000 & 0.0000 & 0.0159 & 0.0045 & 0.0270 & 0.0000 & ND & ND & ND & ND & ND & 0.0182 & ND & ND \\
\hline La & ND & 0.0000 & 0.0000 & 0.0102 & 0.0016 & 0.0134 & 0.0068 & ND & ND & ND & ND & ND & 0.0122 & ND & ND \\
\hline Total & 4.0004 & 4.0098 & 4.0000 & 4.0005 & 4.0051 & 4.0002 & 4.0004 & 3.9986 & 4.0003 & 3.9983 & 3.9854 & 3.9672 & 4.0025 & 4.0042 & 4.0029 \\
\hline
\end{tabular}

Notes: $\mathrm{Fe}_{2} \mathrm{O}_{3}$ contents are calculated stoichiometrically. $\mathrm{ND}=$ not determined. 
Table T10. Geochemical database for shipboard and shore-based analyses of samples, Hole 735B.

\begin{tabular}{|c|c|c|c|c|c|c|c|c|c|c|c|c|c|c|c|c|c|c|c|c|c|c|c|c|}
\hline \multirow[b]{2}{*}{ Data } & \multirow[b]{2}{*}{ Core } & \multirow[b]{2}{*}{ Section } & \multirow{2}{*}{$\begin{array}{l}\text { Interval } \\
(\mathrm{cm})\end{array}$} & \multirow{2}{*}{$\begin{array}{l}\text { Depth } \\
\text { (mbsf) }\end{array}$} & \multirow[b]{2}{*}{ Unit } & \multicolumn{8}{|c|}{ Major element oxide (wt\%) } & \multirow[b]{2}{*}{ Mg\# } & \multirow[b]{2}{*}{$\mathrm{Mg} \# 80$} & \multicolumn{6}{|c|}{ Major element oxide (wt\%) } & \multirow[b]{2}{*}{ s } & \multirow[b]{2}{*}{ LOI } & \multirow{2}{*}{$\begin{array}{l}\text { Total } \\
\mathrm{H}_{2} \mathrm{O}\end{array}$} \\
\hline & & & & & & $\mathrm{SiO}_{2}$ & $\mathrm{TiO}_{2}$ & $\mathrm{Al}_{2} \mathrm{O}_{3}$ & $\mathrm{Fe}_{2} \mathrm{O}_{3} \mathrm{t}$ & $\mathrm{Fe}_{2} \mathrm{O}_{3}$ & $\mathrm{FeO}$ & $\mathrm{MnO}$ & $\mathrm{MgO}$ & & & $\mathrm{CaO}$ & $\mathrm{Na}_{2} \mathrm{O}$ & $\mathrm{K}_{2} \mathrm{O}$ & $\mathrm{P}_{2} \mathrm{O}_{5}$ & $\mathrm{H}_{2} \mathrm{O}^{+}$ & $\mathrm{CO}_{2}$ & & & \\
\hline G & 1D & 1 & $1-5$ & 0.1 & 1 & 52.74 & 0.83 & 17.50 & 8.46 & 2.37 & 5.48 & 0.13 & 5.81 & 65.4 & 63.0 & 9.68 & 4.40 & 0.15 & 0.04 & 0.97 & 0.05 & 0.01 & & 99.19 \\
\hline $\mathrm{GL}$ & 1D & 1 & $90-92$ & 0.9 & 1 & 51.66 & 0.85 & 14.90 & 9.43 & 2.05 & 6.64 & 0.17 & 6.98 & 65.2 & 64.7 & 11.98 & 3.40 & 0.16 & 0.02 & 1.17 & 0.07 & & & 100.05 \\
\hline G & 1D & 1 & $90-92$ & 0.9 & I & 52.27 & 0.86 & 15.08 & 9.54 & 2.12 & 6.68 & 0.17 & 7.07 & 65.4 & 64.7 & 12.12 & $3.40^{*}$ & 0.16 & 0.02 & 1.17 & $0.07^{*}$ & 0.01 & & 100.03 \\
\hline G & 1D & 1 & $117-120$ & 1.2 & 1 & 54.25 & 0.53 & 20.83 & 5.50 & 1.28 & 3.80 & 0.09 & 3.83 & 64.2 & 63.3 & 9.41 & 5.34 & 0.11 & 0.02 & 0.43 & 0.09 & & & 99.58 \\
\hline $\mathrm{GL}$ & 1D & 2 & $91-94$ & 2.4 & 1 & 51.87 & 0.84 & 15.01 & 9.40 & 1.91 & 6.74 & 0.16 & 6.89 & 64.6 & 64.5 & 11.99 & 3.46 & 0.16 & 0.03 & 0.94 & 0.00 & & & 100.00 \\
\hline $\mathrm{GL}$ & 1D & 2 & $91-94$ & 2.4 & 1 & 52.36 & 0.85 & 15.15 & 9.49 & 1.96 & 6.78 & 0.16 & 6.95 & 64.6 & 64.5 & 12.10 & $3.48^{*}$ & 0.16 & 0.03 & 0.94 & & & & 99.98 \\
\hline $\mathrm{GL}$ & $2 \mathrm{D}$ & 1 & $76-80$ & 7.3 & I & 51.35 & 0.42 & 16.93 & 9.09 & 1.85 & 6.52 & 0.17 & 8.39 & 69.6 & 69.6 & 9.66 & 3.30 & 0.25 & 0.04 & 1.13 & 0.00 & & & 100.01 \\
\hline G & $2 \mathrm{D}$ & 2 & $106-109$ & 9.1 & 1 & 51.97 & 0.34 & 18.74 & 6.36 & 1.74 & 4.16 & 0.13 & 6.07 & 72.2 & 70.3 & 11.51 & 3.86 & 0.12 & 0.02 & 0.79 & 0.22 & 0.01 & & 98.89 \\
\hline G & $2 \mathrm{D}$ & 2 & $116-120$ & 9.2 & 1 & 51.45 & 0.35 & 19.31 & 7.46 & 2.54 & 4.43 & 0.13 & 6.62 & 72.7 & 68.7 & 10.23 & 3.91 & 0.15 & 0.02 & 0.79 & 0.24 & & & 99.38 \\
\hline GL & 3D & 1 & $46-49$ & 15.0 & I & 51.93 & 0.55 & 15.64 & 8.26 & 1.64 & 5.96 & 0.16 & 8.05 & 70.7 & 70.7 & 11.07 & 3.53 & 0.16 & 0.07 & 1.24 & 0.00 & & & 100.00 \\
\hline
\end{tabular}

\begin{tabular}{|c|c|c|c|c|c|c|c|c|c|c|c|c|c|c|c|c|c|c|c|c|c|c|c|c|c|}
\hline \multirow[b]{2}{*}{ Data } & \multirow[b]{2}{*}{ Core } & \multirow[b]{2}{*}{ Section } & \multirow{2}{*}{$\begin{array}{l}\text { Interval } \\
(\mathrm{cm})\end{array}$} & \multirow{2}{*}{$\begin{array}{l}\text { Depth } \\
\text { (mbsf) }\end{array}$} & \multirow[b]{2}{*}{ Unit } & \multicolumn{20}{|c|}{ Trace element (ppm) } \\
\hline & & & & & & $\mathrm{F}$ & $\mathrm{Sc}$ & V & $\mathrm{Cr}$ & Co & $\mathrm{Ni}$ & $\mathrm{Cu}$ & $\mathrm{Zn}$ & $\mathrm{Ga}$ & $\mathrm{Rb}$ & $\mathrm{Sr}$ & $\mathrm{Y}$ & $\mathrm{Zr}$ & $\mathrm{Nb}$ & $\mathrm{Ba}$ & La & $\mathrm{Ce}$ & $\operatorname{Pr}$ & $\mathrm{Nd}$ & $\mathrm{Sm}$ \\
\hline G & 1D & 1 & $1-5$ & 0.1 & 1 & 85 & & & 17 & 34 & 27 & 7 & 35 & 19 & & 204 & 18 & 34 & & & 2.0 & 5.0 & & 4.0 & 1.4 \\
\hline $\mathrm{GL}$ & 1D & 1 & $90-92$ & 0.9 & 1 & & 48.4 & 243 & 9 & 40.0 & 32 & 42 & 60 & & 3 & 157 & 19.0 & 26.0 & 0.7 & $<100$ & 1.60 & 5.3 & & 5.3 & 1.99 \\
\hline G & 1D & 1 & $90-92$ & 0.9 & 1 & & & 243 & 9 & & 32 & 42 & 60 & & & 157 & 19 & 26 & & & & & & & \\
\hline $\mathrm{G}$ & 1D & 1 & $117-120$ & 1.2 & 1 & & & & 12 & 18 & 17 & 2 & 33 & 21 & & 256 & 15 & 19 & & & 1.0 & 3.0 & & 2.0 & 1.1 \\
\hline $\mathrm{GL}$ & 1D & 2 & $91-94$ & 2.4 & I & & 48.9 & 254 & 11 & 40.8 & 30 & 42 & 62 & 17 & 3 & 158 & 21.0 & 27.0 & 0.5 & $<75$ & 1.60 & 5.6 & & 5.3 & 2.07 \\
\hline $\mathrm{GL}$ & 1D & 2 & $91-94$ & 2.4 & I & & & 254 & 11 & 42 & 30 & 42 & 62 & 17 & & 158 & 21 & 27 & & & 1.6 & 5.6 & & 5.3 & 2.1 \\
\hline $\mathrm{GL}$ & 2D & 1 & $76-80$ & 7.3 & 1 & & 30.4 & 128 & 9 & 44.9 & 53 & 25 & 56 & 16 & 3 & 176 & 12.0 & 26.0 & 0.6 & $<60$ & 1.50 & 4.5 & & 3.9 & 1.31 \\
\hline G & 2D & 2 & 106-109 & 9.1 & I & & & & 22 & 42 & 58 & 16 & 45 & 17 & & 195 & 13 & 22 & & & & & & & \\
\hline G & 2D & 2 & $116-120$ & 9.2 & I & & & & 14 & 39 & 47 & 15 & 42 & 17 & & 209 & 11 & 22 & & & & & & & \\
\hline $\mathrm{GL}$ & 3D & 1 & $46-49$ & 15.0 & 1 & & 39.4 & 165 & 20 & 37.0 & 51 & 22 & 56 & & 2 & 157 & 36.0 & 37.0 & 2.4 & $<70$ & 8.00 & 25.4 & & 17.1 & 4.70 \\
\hline
\end{tabular}

\begin{tabular}{|c|c|c|c|c|c|c|c|c|c|c|c|c|c|c|c|c|c|c|}
\hline \multirow[b]{2}{*}{ Data } & \multirow[b]{2}{*}{ Core } & \multirow[b]{2}{*}{ Section } & \multirow{2}{*}{$\begin{array}{l}\text { Interval } \\
(\mathrm{cm})\end{array}$} & \multirow{2}{*}{$\begin{array}{l}\text { Depth } \\
\text { (mbsf) }\end{array}$} & \multirow[b]{2}{*}{ Unit } & \multicolumn{13}{|c|}{ Trace element (ppm) } \\
\hline & & & & & & $\mathrm{Eu}$ & Gd & $\mathrm{Tb}$ & Dy & Ho & $\mathrm{Er}$ & $\mathrm{Tm}$ & $\mathrm{Yb}$ & Lu & $\mathrm{Hf}$ & Ta & Th & U \\
\hline G & 1D & 1 & $1-5$ & 0.1 & 1 & 1.0 & 2.0 & & 2.3 & 0.6 & 1.2 & & 1.6 & 0.2 & & & & \\
\hline $\mathrm{GL}$ & 1D & 1 & $90-92$ & 0.9 & 1 & 1.19 & & 0.54 & & & & & 2.09 & 0.32 & 0.82 & 0.020 & 0.12 & $<0.15$ \\
\hline G & 1D & 1 & $90-92$ & 0.9 & 1 & & & & & & & & & & & & & \\
\hline G & 1D & 1 & $117-120$ & 1.2 & 1 & 1.0 & 1.7 & & 1.8 & 0.4 & 1.2 & & 1.2 & 0.2 & & & & \\
\hline GL & 1D & 2 & $91-94$ & 2.4 & 1 & 1.19 & & 0.55 & & & & & 2.17 & 0.31 & 0.87 & 0.016 & $<0.1$ & $<0.15$ \\
\hline $\mathrm{GL}$ & 1D & 2 & 91-94 & 2.4 & 1 & 1.2 & & 0.6 & & & & & 2.2 & 0.3 & 0.87 & 0.02 & $<0.1$ & $<0.15$ \\
\hline GL & 2D & 1 & $76-80$ & 7.3 & 1 & 0.81 & & 0.32 & & & & & 1.22 & 0.19 & 0.68 & 0.015 & $<0.1$ & $<0.15$ \\
\hline G & 2D & 2 & 106-109 & 9.1 & 1 & & & & & & & & & & & & & \\
\hline G & 2D & 2 & $116-120$ & 9.2 & 1 & & & & & & & & & & & & & \\
\hline GL & 3D & 1 & $46-49$ & 15.0 & 1 & 1.15 & & 1.02 & & & & & 4.10 & 0.55 & 1.32 & 0.120 & 0.45 & $<0.15$ \\
\hline
\end{tabular}

Notes: Major element oxides are calculated in wt\%. Data: $\mathrm{G}=$ shore-based data for Leg 118 samples (0-500.7 mbsf) obtained at Justus-Liebig Universität, Giessen, Germany; $\mathrm{P}=$ Leg 176 samples (500.7-1500.8 mbsf) generated at the GeoForschungsZentrum, Potsdam, Germany; L = shore-based data obtained at the Katholieke Universiteit Leuven, Belgium; samples labeled "GL" indicate that the rare earth element (REE) analyses were carried out at Leuven, whereas the remaining data are from Giessen; $\mathrm{S}=\mathrm{Leg} 176$ samples analyzed for major oxides and trace elements; $\mathrm{H}=$ Leg 118 core samples analyzed for major oxides and trace elements. Blank = not analyzed. ${ }^{*}=$ shipboard data. LOI $=$ loss of ignition. Only a portion of this table appears here. The entire table is available in ASCII. 
Table T11. Major and trace element data for reference rocks BM, BHVO-1, and ODP Bas 140.

\begin{tabular}{|c|c|c|c|c|c|c|c|c|c|c|c|c|c|c|c|c|c|c|c|c|c|c|}
\hline \multirow[b]{2}{*}{ Reference rocks } & \multicolumn{11}{|c|}{ Major element oxide (wt\%) } & \multicolumn{11}{|c|}{ Trace element (ppm) } \\
\hline & $\mathrm{SiO}_{2}$ & $\mathrm{TiO}_{2}$ & $\mathrm{Al}_{2} \mathrm{O}_{3}$ & $\mathrm{Fe}_{2} \mathrm{O}_{3} \mathrm{t}$ & $\mathrm{MnO}$ & $\mathrm{MgO}$ & $\mathrm{CaO}$ & $\mathrm{Na}_{2} \mathrm{O}$ & $\mathrm{K}_{2} \mathrm{O}$ & $\mathrm{P}_{2} \mathrm{O}_{5}$ & $\mathrm{H}_{2} \mathrm{O}^{+}$ & $\mathrm{Ba}$ & Co & $\mathrm{Cr}$ & $\mathrm{Ga}$ & $\mathrm{Ni}$ & $\mathrm{Rb}$ & $\mathrm{Sr}$ & $\mathrm{v}$ & $Y$ & $\mathrm{Zn}$ & $\mathrm{Zr}$ \\
\hline BM (mean) $N=30$ & 49.6 & 1.14 & 16.2 & 9.71 & 0.15 & 7.50 & 6.45 & 4.69 & 0.16 & 0.119 & 3.66 & 251 & 41 & 122 & 17 & 63 & 4 & 223 & 209 & 28 & 122 & 96 \\
\hline SD & 0.060 & 0.004 & 0.025 & 0.013 & 0.001 & 0.032 & 0.010 & 0.044 & 0.001 & 0.006 & 0.04 & 11 & 4 & 3 & 1 & 1 & 2 & 2 & 4 & 2 & 1 & 2 \\
\hline \multirow[t]{2}{*}{ BM rec. val.* } & 49.51 & 1.14 & 16.25 & 9.68 & 0.14 & 7.47 & 6.47 & 4.65 & 0.2 & 0.106 & 3.62 & 250 & 36 & 121 & 16 & 57 & 10 & 220 & 190 & 27 & 120 & 100 \\
\hline & 50.01 & 2.76 & 13.8 & 12.53 & 0.17 & 7.31 & 11.51 & 2.28 & 0.52 & 0.28 & ND & ND & ND & 299 & ND & 114 & ND & 400 & ND & 26 & 103 & 172 \\
\hline SD & 0.075 & 0.02 & 0.03 & 0.045 & 0.005 & 0.02 & 0.03 & 0.01 & 0.005 & 0.005 & ND & ND & ND & 5 & ND & 1 & ND & 2.5 & ND & 1 & 1 & 1.5 \\
\hline BHVO rec. val.* & 49.9 & 2.71 & 13.8 & 12.2 & 0.17 & 7.23 & 11.4 & 2.26 & 0.52 & 0.27 & ND & ND & ND & 289 & ND & 121 & ND & 403 & ND & 28 & 105 & 179 \\
\hline Bas 140 (mean) & 50.6 & 1 & 14.6 & 11.3 & 0.19 & 8.21 & 12.5 & 1.78 & ND & 0.08 & 1.15 & ND & ND & 194 & ND & 81 & ND & 47 & ND & 27 & 78 & 49 \\
\hline SD & 0.46 & 0.02 & 0.26 & 0.14 & 0.02 & 0.1 & 0.08 & 0.04 & ND & 0.02 & 0.05 & ND & ND & 4 & ND & 3 & ND & 2 & ND & 2 & 1 & 1 \\
\hline Bas 140 rec. val. ${ }^{\dagger}$ & 50.59 & 0.97 & 14.59 & 11.16 & 0.18 & 8.02 & 12.51 & 1.84 & 0.003 & 0.06 & 1.25 & ND & ND & 175 & ND & 84.1 & ND & 44.5 & ND & 25.9 & 75.8 & 45.4 \\
\hline
\end{tabular}

Notes: ${ }^{*}=$ Govindaraju (1994). $\dagger=$ Sparks and Zuleger (1995). ND = not determined, $\mathrm{SD}=$ standard deviation. rec. val. $=$ analysis normalized to $100 \%$ water free with total iron as Fe $\mathrm{O}_{3}$. 
Table T12. Average chemical compositions for the lithologic units, Hole 735B.

\begin{tabular}{|c|c|c|c|c|c|c|c|c|c|c|c|c|c|c|c|c|c|c|c|}
\hline \multirow[b]{2}{*}{ Unit } & \multirow{2}{*}{$\begin{array}{l}\text { Number of } \\
\text { analyses }\end{array}$} & \multicolumn{6}{|c|}{ Major element oxide (wt\%) } & \multirow[b]{2}{*}{ Mg\# } & \multirow[b]{2}{*}{$\mathrm{Mg} \# 80$} & \multicolumn{9}{|c|}{ Major element oxide (wt\%) } & \multirow{2}{*}{$\begin{array}{l}\text { Total } \\
\mathrm{H}_{2} \mathrm{O}\end{array}$} \\
\hline & & $\mathrm{SiO}_{2}$ & $\mathrm{TiO}_{2}$ & $\mathrm{Al}_{2} \mathrm{O}_{3}$ & $\mathrm{Fe}_{2} \mathrm{O}_{3} \mathrm{t}$ & $\mathrm{Fe}_{2} \mathrm{O}_{3}$ & $\mathrm{FeO}$ & & & $\mathrm{MnO}$ & $\mathrm{MgO}$ & $\mathrm{CaO}$ & $\mathrm{Na}_{2} \mathrm{O}$ & $\mathrm{K}_{2} \mathrm{O}$ & $\mathrm{P}_{2} \mathrm{O}_{5}$ & $\mathrm{H}_{2} \mathrm{O}^{+}$ & $\mathrm{CO}_{2}$ & $S$ & \\
\hline 1 & 18 & 51.4 & 0.5 & 17.2 & 7.9 & 2.2 & 5.2 & 72.7 & 70.8 & 0.1 & 8.2 & 10.6 & 3.6 & 0.2 & 0.1 & 1.1 & 0.12 & 0.01 & 99.4 \\
\hline$\|$ & 91 & 50.7 & 0.6 & 16.5 & 7.7 & 1.6 & 5.4 & 74.2 & 75.1 & 0.1 & 9.2 & 11.8 & 3.0 & 0.1 & 0.0 & 0.9 & 0.10 & 0.05 & 99.2 \\
\hline III & 25 & 50.4 & 1.3 & 15.2 & 10.6 & 2.6 & 7.2 & 67.6 & 67.2 & 0.2 & 8.2 & 11.0 & 3.2 & 0.1 & 0.0 & 0.6 & 0.10 & 0.09 & 99.4 \\
\hline IV & 27 & 43.9 & 5.9 & 12.0 & 20.6 & 6.7 & 12.5 & 44.0 & 41.6 & 0.3 & 5.9 & 8.8 & 3.1 & 0.1 & 0.1 & 0.6 & 0.11 & 0.45 & 99.3 \\
\hline $\mathrm{v}$ & 46 & 50.6 & 0.4 & 16.8 & 5.9 & 1.5 & 4.0 & 80.8 & 79.9 & 0.2 & 9.6 & 13.2 & 2.7 & 0.0 & 0.0 & 0.7 & 0.10 & 0.05 & 99.0 \\
\hline $\mathrm{VI}$ & 33 & 48.4 & 1.4 & 16.4 & 9.7 & 5.5 & 4.9 & 70.2 & 68.1 & 0.3 & 9.6 & 11.2 & 3.0 & 0.1 & 0.1 & 0.5 & 0.06 & 0.09 & 100.1 \\
\hline VII & 13 & 52.6 & 1.1 & 15.5 & 9.5 & 9.2 & ND & ND & 63.8 & 0.2 & 7.0 & 10.8 & 3.4 & 0.4 & 0.3 & ND & ND & ND & 100.7 \\
\hline VIII & 12 & 52.3 & 0.8 & 15.9 & 9.2 & 9.2 & ND & ND & 68.4 & 0.2 & 8.1 & 11.1 & 3.5 & 0.0 & 0.0 & ND & ND & ND & 101.1 \\
\hline IX & 10 & 51.6 & 1.5 & 15.7 & 10.2 & 8.1 & ND & ND & 65.5 & 0.2 & 7.5 & 10.9 & 3.5 & 0.1 & 0.1 & ND & ND & ND & 101.0 \\
\hline$x$ & 64 & 51.8 & 0.8 & 16.3 & 7.7 & 6.8 & ND & ND & 74.1 & 0.1 & 9.2 & 12.5 & 3.0 & 0.1 & 0.1 & ND & ND & ND & 101.5 \\
\hline XI & 70 & 51.8 & 0.6 & 16.6 & 7.6 & 6.5 & ND & ND & 73.7 & 0.1 & 8.8 & 12.3 & 3.0 & 0.1 & 0.1 & ND & ND & ND & 100.9 \\
\hline XII & 42 & 51.9 & 0.5 & 17.8 & 6.2 & 5.2 & ND & ND & 78.7 & 0.1 & 9.1 & 13.2 & 2.8 & 0.0 & 0.0 & ND & ND & ND & 101.6 \\
\hline
\end{tabular}

\begin{tabular}{|c|c|c|c|c|c|c|c|c|c|c|c|}
\hline \multirow[b]{2}{*}{ Unit } & \multirow{2}{*}{$\begin{array}{l}\text { Number of } \\
\text { analyses }\end{array}$} & \multicolumn{10}{|c|}{ Trace element (ppm) } \\
\hline & & V & $\mathrm{Cr}$ & Co & $\mathrm{Ni}$ & $\mathrm{Cu}$ & $\mathrm{Zn}$ & $\mathrm{Ga}$ & $\mathrm{Sr}$ & $\mathrm{Y}$ & $\mathrm{Zr}$ \\
\hline 1 & 18 & 196 & 92 & 37 & 84 & 22 & 42 & 16 & 178 & 18 & 86 \\
\hline II & 91 & 171 & 242 & 38 & 114 & 30 & 37 & 15 & 155 & 16 & 33 \\
\hline IIII & 25 & 251 & 114 & 46 & 61 & 52 & 61 & 17 & 163 & 19 & 34 \\
\hline IV & 27 & 733 & 116 & 85 & 41 & 93 & 129 & 21 & 151 & 29 & 64 \\
\hline V & 46 & 137 & 371 & 36 & 131 & 50 & 33 & 13 & 154 & 17 & 27 \\
\hline $\mathrm{VI}$ & 33 & 256 & 263 & 50 & 191 & 67 & 64 & 15 & 159 & 20 & 68 \\
\hline VII & 13 & 180 & 48 & ND & 58 & 50 & 67 & ND & 157 & 35 & 65 \\
\hline VIII & 12 & 203 & 61 & ND & 66 & 64 & 57 & ND & 161 & 16 & 75 \\
\hline IX & 10 & 278 & 21 & ND & 60 & 63 & 71 & ND & 174 & 35 & 152 \\
\hline$x$ & 64 & 201 & 167 & ND & 103 & 82 & 49 & ND & 160 & 22 & 56 \\
\hline XI & 70 & 166 & 78 & ND & 85 & 79 & 49 & ND & 171 & 20 & 75 \\
\hline XII & 42 & 174 & 167 & ND & 104 & 72 & 36 & ND & 175 & 11 & 26 \\
\hline
\end{tabular}

Notes: All averages adjusted for missing data. ND = not determined. 